\title{
ATIVIDADE MICROBIANA E DIVERSIDADES METABÓLICA E GENÉTICA EM SOLO DE MANGUE CONTAMINADO COM PETRÓLEO
}

\author{
JULIANO DE CARVALHO CURY
}

Dissertação apresentada à Escola

Superior de Agricultura "Luiz de Queiroz", Universidade de São Paulo, para obtenção do título de Mestre em Agronomia, Área de Concentração: Solos e Nutrição de Plantas.

PIRACICABA

Estado de São Paulo - Brasil

Maio - 2002 


\section{ATIVIDADE MICROBIANA E DIVERSIDADES METABÓLICA E GENÉTICA EM SOLO DE MANGUE CONTAMINADO COM PETRÓLEO}

\section{JULIANO DE CARVALHO CURY}

Engenheiro Agrônomo

Orientador: Prof. Dr. Marcio Rodrigues Lambais

Dissertação apresentada à Escola

Superior de Agricultura "Luiz de Queiroz", Universidade de São Paulo, para obtenção do título de Mestre em Agronomia, Área de Concentração:

Solos e Nutrição de Plantas.

\section{PIRACICABA}

Estado de São Paulo - Brasil

Maio - 2002 


\section{Dados Internacionais de Catalogação na Publicação (CIP) DIVISÃO DE BIBLIOTECA E DOCUMENTAÇÃO - ESALQ/USP}

Cury, J uliano de Carva Iho

Atividade mic robiana e diversidades metabólic a e genética em solo de mangue conta mina do com petróleo/ J uliano de Carvalho Cury. - - piracicaba, 2002.

84 p.: il.

Dissertação (mestrado) - Esc ola Superior de Agric ultura Luiz de Queiroz, 2002. Bibliografia.

1. Ecossistemas de mangue 2. Petróleo 3. Poluição do solo I. Título

CDD 631.4

"Permitida a cópia total ou parcial deste documento, desde que citada a fonte - $\mathrm{O}$ autor" 
"............ Porque qualquer um, independentemente das habilitações que tenha, ao menos uma vez na sua vida fez ou disse coisas muito acima da sua natureza e condição, e se a essas pessoas pudéssemos retirar do quotidiano pardo em que vão perdendo os contornos, ou elas a sí próprias por violência se retirassem de malhas e prisões, quantas mais maravilhas seriam capazes de obrar, que pedaços de conhecimento profundo poderiam comunicar, porque cada um de nós sabe infinitamente mais do que julga e cada um dos outros infinitamente mais do que neles aceitamos reconhecer............."

José Saramago (A Jangada de Pedra) 


\section{AGRADECIMENTOS}

À Fapesp, pela bolsa e apoio financeiro para o desenvolvimento da pesquisa;

À Escola Superior de Agricultura "Luiz de Queiroz", Universidade de São Paulo e ao Departamento de Solos e Nutrição de Plantas pela oportunidade;

Ao Prof. Dr. Marcio Rodrigues Lambais pela orientação;

Aos técnicos de laboratório: Denise Mescholotti e Fernando Baldesin pela ajuda nas análises laboratoriais;

Aos professores e funcionários do Departamento de Solos e Nutrição de Plantas;

A todos os colegas do programa de pós-graduação em Solos e Nutrição de Plantas;

Aos colegas e amigos: Adriana, Adrianinha, Beatriz, Beth, Daniele, Denis, Denise, Eduardo, Giuliana, lara, Leandra, Marco Antônio, Raiza, Robinson, Simão, Thaís e Tiago.

À Patrícia pelo companheirismo e carinho. 


\section{SUMÁRIO}

Página

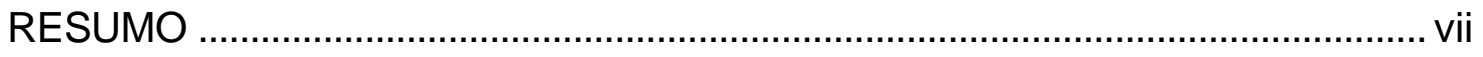

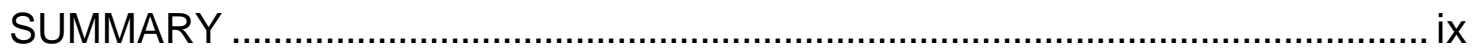

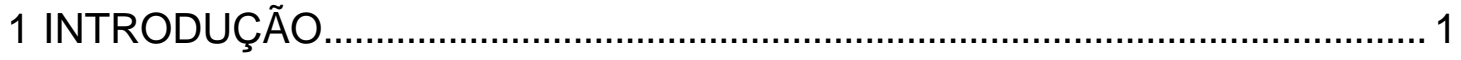

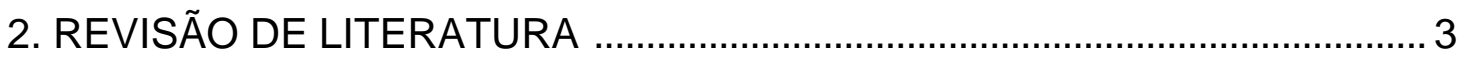

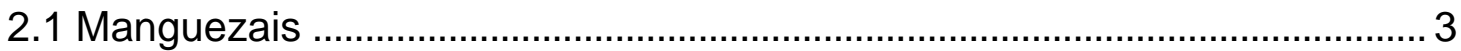

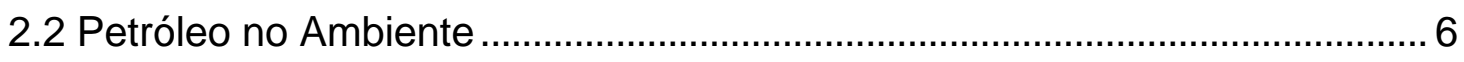

2.3 Indicadores Microbiológicos de Qualidade de Solo ....................................... 10

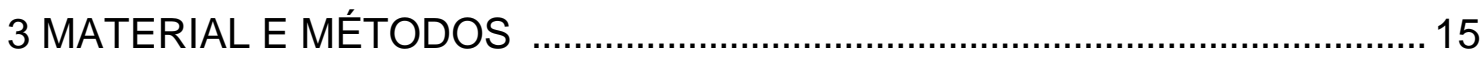

3.1 Área de Estudo ..................................................................................... 15

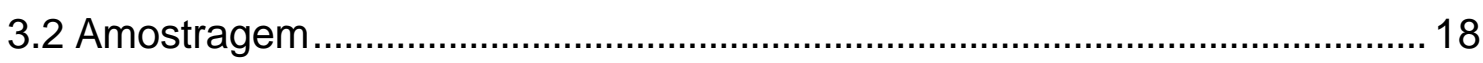

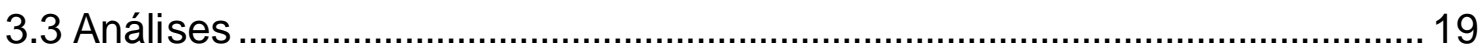

3.3.1 Número mais Provável de Bactérias Heterotróficas Aeróbias (NMP) … 19

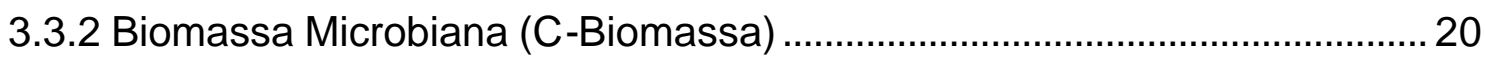

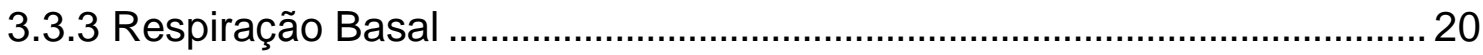

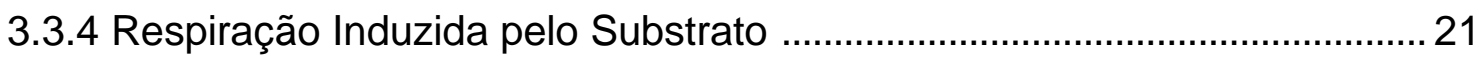

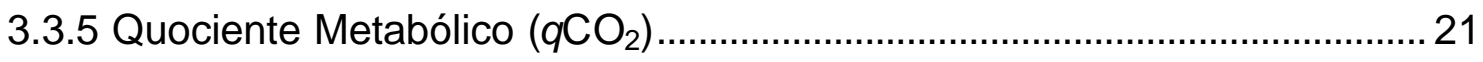

3.3.6 Diversidade Metabólica …..................................................................... 21

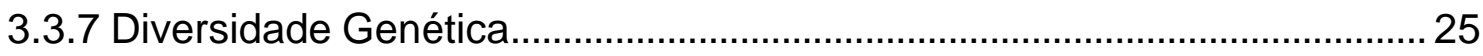

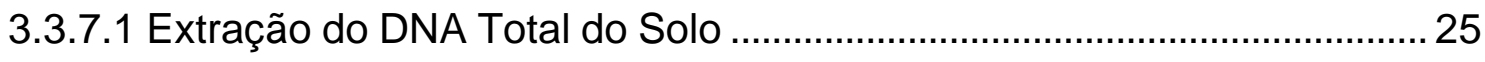

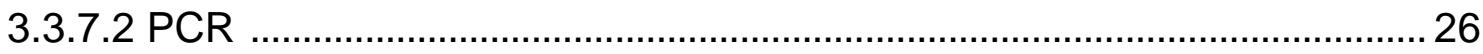




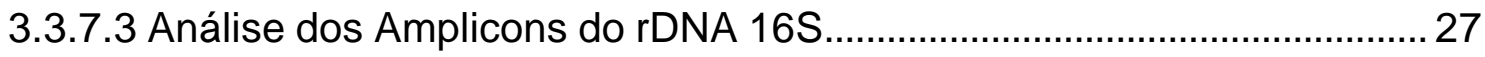

3.3.7.4 Análise da Diversidade Genética ........................................................... 28

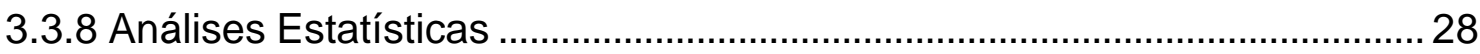

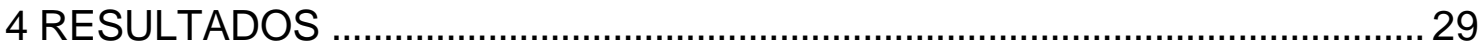

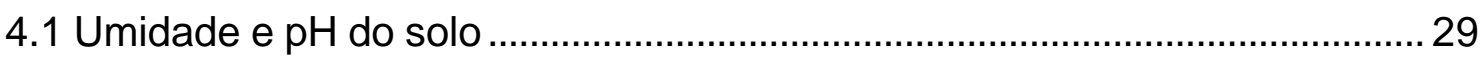

4.2 Número Mais Provável de Bactérias Heterotróficas Aeróbias (NMP)......... 29

4.3 Biomassa Microbiana (C-Biomassa) ........................................................ 29

4.4 Respiração Basal .................................................................................. 32

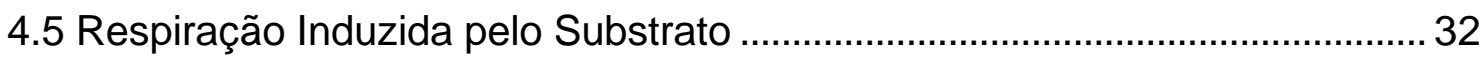

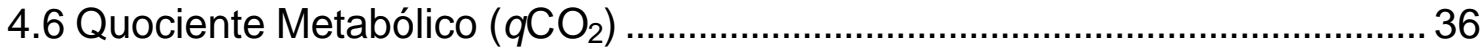

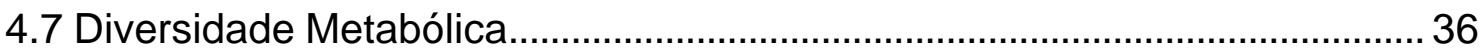

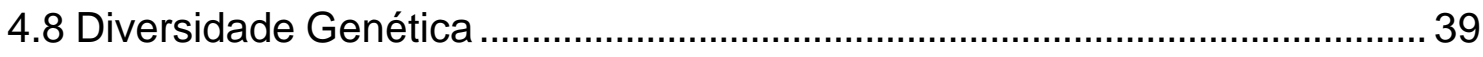

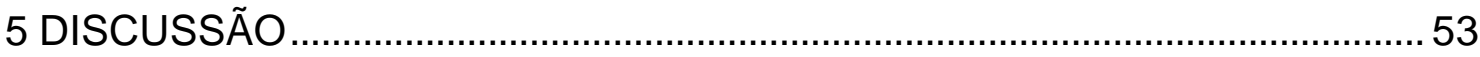

5.1 Número Mais Provável de Bactérias Heterotróficas Aeróbias (NMP) .......... 53

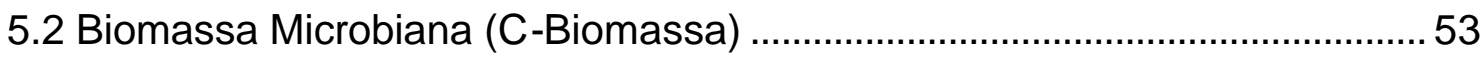

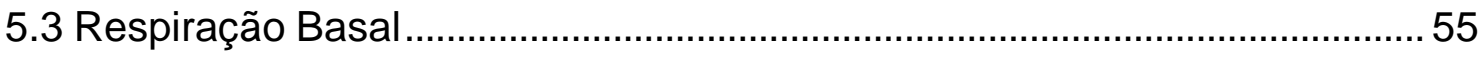

5.4 Respiração Induzida pelo Substrato ……………...................................... 55

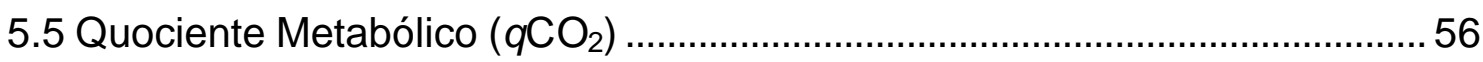

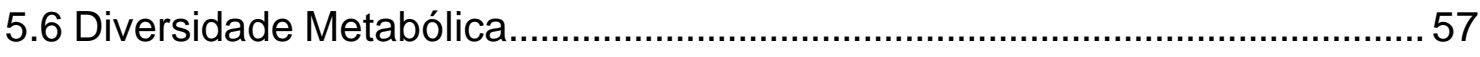

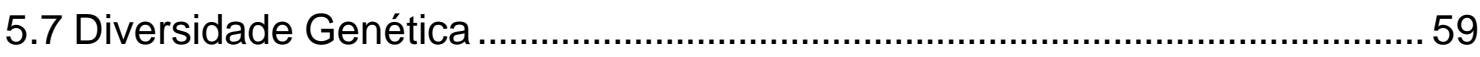

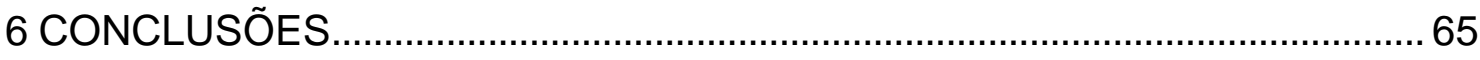

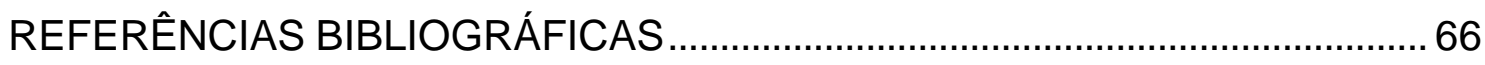




\title{
ATIVIDADE MICROBIANA E DIVERSIDADES METABÓLICA E GENÉTICA EM SOLO DE MANGUE CONTAMINADO COM PETRÓLEO
}

\author{
Autor: JULIANO DE CARVALHO CURY \\ Orientador: Prof. Dr. MARCIO RODRIGUES LAMBAIS
}

\section{RESUMO}

Os manguezais estão sob constante risco de degradação devido a atividades industriais e portuárias nos estuários. Dentre estas atividades, a indústria petroquímica é uma importante fonte de poluição para estas áreas. Os efeitos dos hidrocarbonetos do petróleo sobre a comunidade de bactérias em solo de mangue são pouco conhecidos. O objetivo deste trabalho foi estudar as variações nas atividades e diversidade metabólica e genética da comunidade microbiana em solo de mangue contaminado com petróleo. A área de estudo está localizada no Canal de Bertioga (Santos, SP), e sofreu um derramamento de petróleo em 1983. Nesta área, foram coletadas amostras de 3 pontos, em triplicata, em uma transeção de $300 \mathrm{~m}$ entre o Rio Iriri e o contato mangueencosta. As amostras foram denominadas: P1, próximo às margens do rio; P2, ponto intermediário entre P1 e P2; P3, próximo ao local do derramamento, no contato mangue-encosta. A análise química das amostras mostrou que a poluição remanescente era maior em $\mathrm{P} 3$, diminuindo na direção de $\mathrm{P} 1$, provavelmente devido à maior influência das correntes de fuxo e refluxo de 
maré. De cada ponto foram coletadas subamostras, representando as camadas $0-5,5-10,10-15,15-20,20-30,30-40,40-50,50-60,60-70,70-80,80-90$ e $90-$ $100 \mathrm{~cm}$, com exceção do $\mathrm{P} 3$, onde as amostras foram coletadas até $80 \mathrm{~cm}$. Foram realizadas determinações de: pH, Umidade do Solo, Número Mais Provável (NMP) de Bactérias Heterotróficas Aeróbias, C-biomassa, Respiração Basal (RB), Respiração Induzida pelo Substrato (RIS), Quociente Metabólico $\left(q \mathrm{CO}_{2}\right)$, Diversidade Metabólica e Diversidade Genética. O NMP de bactérias heterotróficas aeróbias foi em média 3,5 vezes maior no P3 do que no P1 e P2. A biomassa microbiana não variou com o ponto de amostragem, mas foi afetada significativamente pelo fator PROFUNDIDADE. Os maiores valores de C-biomassa foram observados na camada de 0 a $5 \mathrm{~cm}$. A RB foi afetada tanto pelo fator PONTO quanto pelo fator PROFUNDIDADE. No P3 a RB foi em média 39\% maior do que no P1 e P2. Entre as profundidades, as amostras de 50 a $100 \mathrm{~cm}$ apresentaram maior RB. A RIS foi afetada pela interação dos fatores PONTO e PROFUNDIDADE, sendo maior na camada de 0 a $5 \mathrm{~cm}$ do P3. $\mathrm{O} q \mathrm{qCO}_{2}$ foi em média $45 \%$ menor no P2 do que no P1 e P3. A diversidade metabólica, avaliada pela capacidade de utilização de substratos de carbono não diferiu entre os pontos, mas apresentou decréscimo gradativo em função do aumento da profundidade. A separação de amplicons de rDNA 165 de Bacteria revelou uma diminuição da Riqueza de Espécies $\left(S_{E}\right)$ no P3, possivelmente devido à presença do petróleo. Essas alterações foram menores para Archaea. A análise de agrupamento hierárquico mostrou que as comunidades de Bacteria foram mais similares entre os pontos de amostragem do que entre as profundidades. Já, as comunidades de Archaea foram mais similares entre as profundidades do que entre os pontos de amostragem. De uma maneira geral, os resultados sugerem que, após 20 anos da contaminação com petróleo, as comunidades microbianas, principalmente de Bacteria, na área em estudo ainda não restabeleceram seu equilíbrio. 


\title{
MICROBIAL ACTIVITY AND METABOLIC AND GENETIC DIVERSITIES IN OIL CONTAMINED MANGROVE SOIL
}

\author{
Author: JULIANO DE CARVALHO CURY \\ Adviser: Prof. Dr. MARCIO RODRIGUES LAMBAIS
}

\section{SUMMARY}

Mangroves are at constant risk of degradation due to industrial and harbor activities in the estuaries. Among potentially harmful activities, the petrochemical industries are important contamination sources for mangroves. Information on the effects of oil hydrocarbons on bacterial communities in mangrove soil is lacking. The objective of this work was to determine variations in the activities and metabolic and genetic diversities of microbial communities in an oil contaminated mangrove soil. The area studied is located in the Bertioga Channel (Santos, SP), and was contaminated by an oil spill in 1983. Samples were collected from three spots in a $300 \mathrm{~m}$ transect between the Iriri River and the mangrove-slope contact, and named: $\mathrm{P} 1$, spot in the vicinity of the riverbank; $\mathrm{P} 2$, intermediary spot; $\mathrm{P} 3$, spot in the vicinity of the oil spill (mangrove-slope contact). Chemical analyses of samples from these spots showed that the remaining oil concentration was higher at P3 and decreased towards P1, probably due the influence of flooding and tide reflux. From each spot, triplicate subsamples representing layers: $0-5,5-10,10-15,15-20,20-30,30-40,40-50$, $50-60,60-70,70-80,80-90$ and $90-100 \mathrm{~cm}$ (except in P3, where sampling at depths higher than $80 \mathrm{~cm}$ was not possible) were collected. Soil samples were 
subjected to the following analyses: $\mathrm{pH}$, Soil Humidity, Most Probable Number of Heterotrophic Bacteria (MPN), Gbiomass, Basal Respiration (BR), Substrate Induced Respiration (SIR), Metabolic Quotient $\left(q \mathrm{CO}_{2}\right)$, Metabolic Diversity and Genetic Diversity. The MPN of aerobic heterotrophic bacteria was 3.5 times higher in P3 than in P1 and P2. The microbial biomass did not show significant differences between sampled spots. However, significant differences were observed for sampling depths. The highest values of C-biomass were observed in 0 to $5 \mathrm{~cm}$ layers. The BR was significantly affected by factors SAMPLING SPOT and SAMPLING DEPTH. In P3, the average BR was 39\% higher than in $\mathrm{P} 1$ and P2. Among sampling depths, the highest values for BR were observed at 50 to $100 \mathrm{~cm}$. The SIR was significantly affected by he interaction between factors SAMPLING SPOT and SAMPLING DEPTH, and was highest in P3 at 0 to $5 \mathrm{~cm}$. The average $\mathrm{qCO}_{2}$ was $45 \%$ lower in P2 than in $\mathrm{P} 1$ and $\mathrm{P} 3$. The metabolic diversity, based on the ability to use C-sources, did not differ among sampling spots, but showed a gradual decrease at greater depths. Analyses of Bacteria 16S rDNA amplicons by DGGE revealed lower species richness $\left(S_{E}\right)$ in $\mathrm{P} 3$, as compared to $\mathrm{P} 1$ and $\mathrm{P} 2$, which was probably associated with residual oil contamination. Archaea showed less variation in the samples. Hierarchical clustering showed that Bacteria community structures were more similar among sampling spots than sampling depths, whereas Archaea community structures were more similar among sampling depths than between sampling spots. In general, these results suggest that 20 years after an oil spill, Bacteria communities had been altered in a fashion that changed the community structure, but which did not affect their activity or function. 


\section{INTRODUÇÃO}

Em todo o mundo, as áreas estuarinas estão sob constante risco de degradação ambiental devido a atividades industriais e portuárias. Dentre estas atividades podemos citar a indústria petroquímica e o transporte de petróleo e seus derivados. Os hidrocarbonetos do petróleo provenientes de derramamentos são importantes poluidores destas regiões, as quais possuem ecossistemas importantes e frágeis, como os manguezais.

Os manguezais desempenham papel importante na manutenção da vida marinha. Devido a características como alta concentração de matéria orgânica e condições anóxicas, poluentes como hidrocarbonetos de petróleo acumulam-se com facilidade nos solos de mangue, podendo em longo prazo causar desequilíbrios em processos essenciais para a manutenção dos ecossistemas.

Processos importantes como a ciclagem de nutrientes estão diretamente relacionados com a atividade e diversidade das comunidades microbianas do solo. Poluentes de origem antrópica podem alterar a estrutura das comunidades microbianas, e causam desequilíbrios ecológicos que podem levar à extinção de espécies importantes para a manutenção do ecossistema. Em última análise, esse processo poderá resultar em diminuição da ciclagem de nutrientes e crescimento de plantas.

Estudos de populações microbianas do solo normalmente se restringem à determinação do número total de microrganismos cultiváveis, biomassa microbiana, taxa respiratória, etc, os quais são, na maioria dos casos, pouco sensíveis a impactos ambientais. 
Os avanços nas técnicas de biologia molecular aplicadas ao estudo da ecologia de microrganismos em sistemas complexos têm contribuído significativamente para o entendimento dos impactos causados por atividades antrópicas sobre as comunidades microbianas do solo, inclusive de microrganismos não-cultiváveis.

Dados sobre atividade e diversidade de Bacteria e Archaea em solos de mangue brasileiros são inexistentes, mas poderiam ser úteis para a avaliação do impacto causado por ações antrópicas, contribuindo para a geração de índices de qualidade biológica de solos e para o melhor entendimento destes ecossistemas peculiares.

O objetivo deste trabalho é estudar as variações de atividade e diversidade metabólica e genética da comunidade microbiana em solo de mangue contaminado com petróleo. 


\section{REVISÃO DE LITERATURA}

\subsection{Manguezais}

Os manguezais desempenham papel essencial na manutenção da biodiversidade marinha, funcionando como berçário e fonte de alimento para peixes e outros animais (Shriadah, 1998; Getter et al., 1984). Dentre os principais fatores condicionantes da ocorrência, estrutura e funcionamento desses ecossistemas, podemos destacar: temperaturas tropicais, substratos aluviais, proteção contra ondas, presença de água salgada e considerável amplitude de marés (Walsh, 1974). Sua formação e evolução estão associadas ao aporte de materiais sedimentares provenientes tanto do mar quanto do continente, tornando-os ambientes de transição de alta produtividade (Woodwell et al., 1977; Delaune et al., 1978). Os manguezais são formados em regiões de planícies costeiras ou vales alagados limitados por baixios, em estuários e deltas que possuem águas ricas em material em suspensão e que não são perturbadas, constituindo ecossistemas de baixa energia (Vannuci 1999).

As variações espaciais de características como temperatura e salinidade da água, do solo e de cursos de água nos manguezais são grandes (Thom, 1982). A salinidade das águas dos manguezais pode variar de $0,5 \%$ a 30\% (Odum et al., 1982; Yañez-Arancibia,1986). Na superfície do solo, a salinidade em geral diminui com a distância dos rios e canais, exceto nos casos de regiões desprovidas de vegetação, as quais 
sofrem evaporação de água pela insolação e circulação do ar (Mogg, 1963; Weiss \& Kinner, 1971). Os teores de oxigênio dissolvido nas águas dos canais responsáveis pela inundação geralmente obedecem um padrão decrescente, desde a área próxima àbaía até a parte superior do manguezal (Tundisi et al., 1978).

A vegetação dos manguezais é altamente especializada e representada por espécies arbóreas como Rhizophora mangle, Laguncularia racemosa, Avicennia tormentosa e Avicennia Schaueriana, entre outras, altamente adaptadas a condições de solos alagados, com baixas concentrações de oxigênio e salinidade variável. Estas espécies apresentam estruturas de adaptação ao mangue, tais como raízes escora (responsáveis pela sustentação das árvores sobre o sedimento) e glândulas excretoras de sais (conferem tolerância às elevadas concentrações de sais) (Rossi \& Mattos, 1992; Odum, 1972).

Os manguezais no Brasil podem ser encontrados desde o extremo norte, no Amapá, até o sul de Santa Catarina, na foz do Rio Araranguá (Aquino, 1987). A região da Baixada Santista, formada pelos municípios de Bertioga, Cubatão, Guarujá, Itanhaém, Mongaguá, Peruíbe, Praia Grande, Santos e São Vicente possui uma área total de cobertura vegetal de $1.716,6 \mathrm{~km}^{2}$, sendo que aproximadamente $6 \%$ corresponde a vegetação de mangue.

Em todo o mundo, os manguezais estão sujeitos a impactos naturais (e.g. furacões) e processos de erosão, além dos impactos antrópicos associados às atividades das civilizações nas zonas costeiras (NOAA, 2002). Estima-se que mais de 1 milhão de hectares de manguezais são perdidos anualmente no mundo todo (Moscatelli, 1999). O desenvolvimento de atividades industriais, portuárias, pesqueiras, de exploração mineral, turísticas, entre outras, sem planejamento adequado, vem colocando em risco os atributos básicos dos estuários e ecossistemas associados, como os manguezais. Estas atividades favorecem o acúmulo de diferentes poluentes no solo, entre eles o petróleo, gerando impactos consideráveis, inclusive sobre a microbiota. 
Poluentes como petróleo, metais pesados e lixo industrial e urbano afetam diretamente a vegetação de mangue, alterando a capacidade respiratória e osmoregulatória das raízes, podendo levar as plantas à morte (Getter et al. 1981). Como resultados, tem-se, entre outros, diminuição da qualidade da água, da produtividade, da biodiversidade e dos valores estéticos e paisagísticos do sistema estuarino (Fildeman, 1999).

Nos ambientes de manguezais podem ocorrer vários tipos de solos, entre eles, NEOSSOLOS QUARTZARÊNICOS marinhos, ESPODOSSOLOS FERROCÁRBICOS, NEOSSOLOS FLÚVICOS, GLEISSOLOS e ORGANOSSOLOS TIOMÓRFICOS (Lani, 1998; Fitzpatrick et al., 1993; Bandyopadhyay \& Maji, 1995; Ukpong, 1997).

Os solos de mangue são formados pela deposição de partículas de origem terrígena e marinha, orgânicas e inorgânicas, que estão em suspensão na água, e que se movimentam em função das correntes de fluxo e refluxo das marés. Através desta ação mecânica, as partículas grossas se depositam primeiro, seguidas das partículas de argila e silte, as quais se agregam e decantam por floculação (Vannucci, 1999; Stralher \& Stralher, 2000; Woodhouse et al., 1974). Apesar da origem e transporte dos sedimentos serem similares, os solos de mangue podem apresentar características diferentes devido à variação na intensidade de geração e do transporte dos mesmos. O predomínio da fração silte é frequente em canais de maré, devido às inundações diurnas e a deposição de sedimentos. As frações mais finas de argila são regularmente removidas e enxaguadas do manguezal por marés vazantes (Gamero, 2001). Já, os teores de matéria orgânica nos sedimentos apresentam um amplo espectro de variação espacial. Segundo Gamero (2001), a variação espacial do teor de matéria orgânica fina está relacionada diretamente com o tamanho das partículas inorgânicas do sedimento. Normalmente, as maiores concentrações de matéria orgânica são observadas em locais com sedimento de menor granulometria e altimétricamente mais baixos, onde o fluxo de água é reduzido (Brereton, 1971; Thom, 1982 e 1984; 
Soriano-Sierra, 1990 e 1992). Esses solos também apresentam amplas variações nos valores de $\mathrm{pH}, \mathrm{CTC}$, capacidade de retenção de água, potencial redox, salinidade e nitrogênio e fósforo extraível (Cardona \& Botero, 1998), além de variações na composição mineralógica.

Alguns solos de mangue são ácidos ou tiomórficos, formados após a drenagem de materiais ricos em pirita $\left(\mathrm{FeS}_{2}\right)$, a qual é formada em ambientes redutores com presença de matéria orgânica, $\mathrm{Fe}^{+3}$, enxofre proveniente do mar e mircrorganismos ( e.g. Thiobacillus ferrooxidans). As bactérias decompõem a matéria orgânica sob condições anaeróbias, reduzindo os íons sulfato a sulfito e o $\mathrm{Fe}^{+3}$ a Fe ${ }^{+2}$, e levando àformação da pirita, que é estável nessas condições. No entanto, quando os solos são drenados, ocorre a oxidação da pirita e a produção de ácido sulfúrico, causando uma redução dos valores de $\mathrm{pH}$ e, em muitos casos, formação de solos sulfato-ácidos em áreas mais elevadas (Demas \& Rabenhorst, 1999; Vannucci, 1999).

No litoral do Estado de São Paulo os solos de mangue desenvolvem-se associados aos cursos de água e áreas encharcadas e calmas, com predomínio de NEOSSOLOS QUARTZARÊNICOS marinhos (Rossi, 1999).

\subsection{Petróleo no Ambiente}

O petróleo, originado da transformação de grandes deposições fósseis, é uma mistura com composição variável de compostos orgânicos, predominantemente hidrocarbonetos (GESAMP, 1993).

Desde o primeiro grande acidente em 1969, no canal da Inglaterra, ocorreram mais de 40 grandes derramamentos marinhos de petróleo. Os vazamentos durante o transporte são responsáveis por $45,5 \%$ do petróleo lançado ao mar, enquanto que os vazamentos de atividades em terra vêm em segundo lugar, representando $29 \%$ (Sloan, 1999). 
A contaminação dos manguezais devido a derramamentos de petróleo é frequente (Getter et al. 1981), ficando a flora e fauna desses ecossistemas vulneráveis ao poluente, devido principalmente à facilidade de sua acumulação no solo (Scherrer \& Mille, 1989). As condições de inundação e as características da vegetação, com suas raízes abundantes, formando uma malha superficial, dificultam o acesso æ̀ regiões contaminadas, impedindo a descontaminação imediata (NOAA, 1996).

Após a entrada no ambiente, o petróleo sofre alterações de suas características originais, devido a fatores físicos (evaporação, dissolução, dispersão, oxidação fotoquímica, adsorção às partículas, etc) e principalmente biológicos (biodegradação) (Sloan, 1999). As transformações físicas e biológicas são reguladas pelas características específicas do derramamento e do ambiente atingido. Assim, o grau de impacto ambiental e persistência do petróleo no ambiente dependem de fatores como: habitat atingido, tipo e quantidade do óleo derramado, espécies de organismos atingidos, época do ano (pode afetar o ciclo de vida das espécies), condições hidrográficas e meteorológicas (pode afetar a dispersão do petróleo), clima, frequência e duração da exposição ao petróleo e práticas utilizadas na tentativa de descontaminação (Sloan, 1999).

Alguns métodos de medição podem ser utilizados para a avaliação do impacto causado pela presença de petróleo em um ambiente, entre eles: porcertagem de árvores vivas e mortas em um transecto ou quadrante, abundância e diversidade de espécies arbóreas, densidade e condição das sementes produzidas, estimativa da biomassa vegetal e observação da fauna dominante no solo de mangue (Michel, 2002).

O petróleo e seus derivados podem persistir por mais de 20 anos nos manguezais, antes que a vegetação se recupere totalmente (Michel, 2002). Esta alta persistência é explicada pela lenta biodegradação dos hidrocarbonetos de petróleo, devido à limitação de oxigenação do meio e lenta ciclagem dos nutrientes, essenciais para a atividade microbiana aeróbia 
(Scherrer \& Mille, 1989). A persistência dos hidrocarbonetos depende também da exposição do sítio contaminado aos fluxos de água marinha, influenciados pelas marés. A maior frequência de exposição a estes fluxos pode acelerar a remoção dos hidrocarbonetos, contribuindo para a recuperação da vegetação (Michel, 2002).

Os efeitos crônicos da poluição com petróleo são pouco conhecidos (Strickland, 1990). Os efeitos tóxicos imediatos do petróleo tendem a ser causados principalmente por moleculas de baixa massa molecular e que se degradam mais rapidamente. Já os efeitos tóxicos crônicos são devidos às moléculas de alta massa molecular, geralmente aromáticas, que apresentam menor toxicidade, mas são persistentes, causando efeitos mais duradouros (Spies et al., 1996). Clark \& Finley (1982) consideram os efeitos crônicos mais significativos do que os efeitos imediatos. Pequenas quantidades de petróleo podem ter efeitos de longo prazo na diminuição da diversidade de espécies em um sistema (Howarth, 1991; Nelson-Smith, 1982). A diminuição da diversidade de espécies vegetais e de invertebrados marinhos em um ambiente contaminado é causada principalmente por efeitos fisiológicos, carcinogênicos e citogenéticos de longo prazo, alterando a reprodução, crescimento, respiração, movimentação e susceptibilidade a doenças (Suchanek, 1993).

Os efeitos crônicos são de difícil diagnóstico, devido à dificuldade de quantificar a exposição do ambiente ao petróleo e ao fato de injúrias iniciais e da dinâmica da recuperação poderem mascarar esses efeitos (Bienert \& Pearson,1995; Spies et al., 1996; Bue et al., 1998).

Foi observado que plantas de mangue diminuíram drasticamente a produção de sementes durante 17 meses após um derramamento de petróleo no Sudeste da Austrália (Clarke \& Ward, 1994). Já, em outras regiões, a presença do óleo exerceu impacto negativo sobre a vegetação durante 17 anos (Baker et al., 1993).

O conhecimento da capacidade de recuperação de ecossistemas impactados passa pelo estudo das suas características físico-químicas e 
biológicas, assim como de suas interações com os componentes antropogênicos.

Muitos microrganismos são capazes de degradar os hidrocarbonetos do petróleo. Alguns são degradadores de alcanos, outros de aromáticos e alguns conseguem metabolizar ambos (Atlas, 1981; Leahy \& Colwell, 1990; Atlas \& Bartha, 1992). Alcanos $C_{10}$ a $C_{26}$ são mais facilmente degradados. Entre os aromáticos, os de baixa massa molecular como o benzeno, tolueno e xileno, que estão entre os componentes tóxicos do petróleo, são facilmente degradados pelos microrganismos marinhos. Moléculas com estruturas mais complexas, contendo ramificações e anéis aromáticos são degradadas por um número menor de microrganismos e com uma taxa de degradação menor, se comparadas com moléculas de estrutura mais simples.

O petróleo crú no ambiente nunca é completamente degradado, sempre persistindo resíduos mais complexos, geralmente contendo compostos asfálticos, os quais são mais inertes, possuem baixa disponibilidade e toxicidade e não apresentam grandes riscos ecológicos aparentes (Atlas, 1995).

Os microrganismos capazes de degradar hidrocarbonetos do petróleo estão largamente distribuídos pelos oceanos. Vários gêneros de bactérias presentes no mar são responsáveis pela degradação do petróleo (Floodgate, 1995). Apesar da importância destes microrganismos para a restauração do ecossistema, os estudos das bactérias marinhas em ambientes contaminados são escassos (Sloan, 1999). Várias espécies de Pseudomonas, que utilizam normalmente hidrocarbonetos produzidos por plantas, algas e outros organismos, estão entre estes potenciais degradadores de hidrocarbonetos do petróleo (Atlas, 1995). Segundo Braddock et al. (1996), as populações de bactérias degradadoras de hidrocarbonetos em sedimentos marinhos contaminados com petróleo são maiores do que nos nãocontaminados. Quando um ambiente marinho é contaminado com petróleo, a proporção de microrganismos degradadores de hidrocarbonetos aumenta rapidamente, com dominância de populações de bactérias que contêm 
plasmídeos com genes para a degradação de hidrocarbonetos (Atlas, 1995). A proporção destes microrganismos aumenta de menos de $1 \%$, em ambientes marinhos não contaminados, para mais de 10\%, em ambientes marinhos contaminados (Atlas, 1981).

A biodegradação dos hidrocarbonetos do petróleo se inicia com a oxidação do substrato por oxidases, em condições aeróbias. Os alcanos são transformados em ácidos carboxílicos, os quais são também metabolizados pelos microrganismos. Os compostos aromáticos são geralmente hidroxilados, formando dióis, os quais são degradados a catecóis, e esses são posteriormente também metabolizados. Alguns fungos podem produzir formas carcinogênicas de catecóis, mas como o ambiente marinho é dominado por bactérias, a mineralização dos hidrocarbonetos não produz metabólitos tóxicos.

Em ambientes marinhos, a biodegradação dos hidrocarbonetos do petróleo é geralmente limitada pelas baixas concentrações de oxigênio, fosfato e nitrogênio. Nos ambientes com alta energia (e.g. encostas rochosas), os nutrientes $\mathrm{P}$ e $\mathrm{N}$ são os fatores mais limitantes. Já nos ambientes com baixa energia (e.g. mangues), onde normalmente não há limitação de $\mathrm{P}$ e $\mathrm{N}$, a taxa de biodegradação é limitada pela anoxia, resultando em prolongada persistência do petróleo. (Atlas, 1995; Teal et al., 1992).

\subsection{Indicadores Microbiológicos da Qualidade de Solos}

Os microrganismos representam a forma de vida mais abundante e diversificada no planeta (Whitman et al., 1998). A diversidade da microbiota do solo é extremamente elevada. Através da análise da cinética de reassociação de DNA, tem sido estimado que um grama de solo pode conter mais de 10.000 genomas diferentes (Torsvik et al., 1998).

A organização e funcionamento dessas comunidades é que governam as transformações bioquímicas que ocorrem no ecossistema solo. A microbiota do solo é responsável não somente pela formação do húmus e 
ciclagem de nutrientes, mas pela definição da estrutura física e muitas outras funções (Lynch \& Bragg, 1985).

Biodiversidade pode ser definida como abundância da vida, indicada pela variedade da biota e inter-parentesco de processos bioquímicos no solo (Kennedy \& Smith, 1995).

Atividades antrópicas podem afetar o funcionamento e diminuir a diversidade dos ecossistemas, resultando em desequilíbrios ecológicos de consequências imprevisíveis, e na extinção de espécies essenciais à manutenção do ecossistema (Mello \& Azevedo, 1998). No solo, a diminuição da diversidade microbiana pode resultar em diminuição da ciclagem de nutrientes e crescimento de plantas (Reber, 1992).

O estudo da diversidade microbiológica dos solos pode ajudar na identificação de alterações ambientais associadas a distúrbios, como a presença de poluentes, além de ser importante para aumentar nosso conhecimento sobre os recursos genéticos disponíveis e a sua distribuição sobre a Terra e aumentar nosso conhecimento sobre o papel funcional dessa diversidade (Kennedy \& Smith, 1995).

Estudos sobre o impacto de alterações ambientais nas populações microbianas e suas atividades têm sido amplamente reportados, mas são muitas vezes restritos a avaliação de parâmetros básicos, como número total de microrganismos, biomassa microbiana, taxa respiratória total e atividades enzimáticas envolvidas na mineralização do C e $\mathrm{N}$ orgânicos (Alexander, 1977). Avaliações destas atividades, embora críticas para o entendimento do ecossistema, podem não refletir alterações na estrutura das comunidades microbianas devido à elevada redundância fisiológica e às complexas relações entre comunidades particulares (Kennedy \& Smith, 1995). Os processos de mineralização do $\mathrm{C}$ e $\mathrm{N}$ orgânicos, por exemplo, apresentam alto grau de redundância, isto é, diferentes populações de microrganismos podem, em diferentes condições ambientais, realizar esses processos. Assim a diminuição da atividade de uma população de microrganismos por alteração das condições 
ambientais poderá ser compensada pelo aumento da atividade de outra população, sem alteração significativa da atividade total da comunidade. Atividades apresentando alto grau de redundância dificilmente se correlacionam com alterações da qualidade do solo, embora esses parâmetros sejam úteis na determinação das taxas de degradação de materiais orgânicos no solo (Brookes, 1995).

Stenberg (1999) enfatiza que nenhum indicador individualmente conseguirá descrever e quantificar todos os aspectos da qualidade do solo. Nem mesmo uma única função do solo pode ser avaliada, já que deve haver uma relação entre todos os atributos do solo. Assim, um número mínimo de indicadores deve ser selecionado. Os critérios para a seleção de indicadores relacionam-se, principalmente, com a sua utilidade em definir os processos do ecossistema. Estes integram as propriedades físicas, químicas e biológicas, além da sensibilidade a fatores como poluição, manejo e variações climáticas (Doran, 1997).

A poluição do solo pode conduzir a um decréscimo na diversidade microbiana em termos de abundância de espécies, devido à extinção de espécies não adaptadas ao estresse imposto; mas, pode também ocasionar o enriquecimento de espécies particulares mais adaptadas a esse estresse (Atlas, 1984).

Um grande avanço nos estudos de ecologia microbiana foi dado com o advento de técnicas moleculares, baseadas na análise do DNA de microrganismos retirado diretamente dos ambientes naturais, sem a necessidade de multiplicação prévia das células (Benlloch et al., 1995). O estudo da microbiota utilizando meios de cultura apresenta grandes limitações (Amann et al., 1995), já que somente uma pequena porcentagem $(0,1$ a $0,5 \%)$ dos microrganismos do solo podem ser cultivados em laboratório (Torsvik et al., 1990). Além disso, os microrganismos que conseguem crescer em meios artificiais não são necessariamente metabólica ou numericamente dominantes no meio natural de onde foram retirados (Muyzer \& Ramsing, 1995), havendo 
uma seleção muito forte em função da habilidade do microrganismo em se desenvolver em meio com altas concentrações de nutrientes e geralmente em condições aeróbias (Hugenholtz, 2002). O emprego de técnicas moleculares se tornou possível a partir dos estudos de Pace et al. (1986), pioneiros nas análises de estrutura de comunidades microbianas utilizando as informações da sequência de nucleotídeos do DNA ribossômico (rDNA) 16S. Além da alta conservação deste gene entre as espécies, existem outras razões para a larga utilização do rDNA 16S (Amann \& Ludwig, 2000):

1 - A grande quantidade de rRNA na maioria das células 2 - A aparente ausência de transferência genética lateral 3 - Um tamanho satisfatório, com cerca de 1500 nucleotídeos, permitindo inferências filogenéticas.

A variabilidade nas sequências do rDNA $16 S$ pode ser avaliada através de eletroforese em gel de poliacrilamida com gradiente desnaturante (DGGE). Essa técnica foi utilizada primeiramente por Muyzer et al. (1993) e consiste na separação dos fagmentos de DNA (principalmente do rDNA 16S) em um gel de poliacrilamida contendo um gradiente linear de formamida e uréia. As variações na composição de nucleotídeos dos diferentes fragmentos de DNA determinam seu comportamento de migração no gel, fazendo com que fragmentos diferentes terminem sua migração em posições diferentes (Muyzer, 1999). O comportamento de migração do fragmento de DNA no DGGE é governado não apenas pela composição de nucleotídeos (conteúdo de $G+C$ ), mas também pelas interações entre estes dentro da molécula (Breslauer et al, 1986; Sugimoto et al., 1996).

A relação entre diversidade microbiana e qualidade do solo tem sido muito discutida, mas não foi ainda completamente definida. $O$ tempo necessário para o ecossistema retornar ao seu estado inicial, após um distúrbio qualquer, define a resiliência do sistema. Quanto maior esse tempo, menor a resiliência. Se a diversidade das comunidades microbianas do solo está diretamente relacionada com sua resiliência, ainda não está definido. No 
entanto, esta é uma hipótese plausível, se considerarmos que a diminuição de diversidade pode resultar em diminuição da redundância de funções bioquímicas e consequente redução da diversidade metabólica (Reber, 1992).

Dados sobre alterações da diversidade genética e/ou metabólica dos microrganismos em solos de mangue são inexistentes, mas poderiam ser úteis para avaliar o impacto causado pela ação antrópica nestes ecossistemas peculiares. Tanto análises de tamanho e atividade, quanto de estrutura das comunidades microbianas podem contribuir significativamente para a geração de índices de qualidade biológica de solos. 


\section{MATERIAL E MÉTODOS}

\section{1 Área de Estudo}

A área em estudo, compreendida entre $46^{\circ} 12^{\prime} 28^{\prime \prime}$ e $46^{\circ} 12^{\prime} 29^{\prime \prime}$ de Longitude Oeste e $23^{\circ} 53^{\prime} 49^{\prime \prime}$ e $23^{\circ} 53^{\prime} 43^{\prime \prime}$ de Latitude Sul, está localizada no Canal de Bertioga, Santos, SP (Figura 1A). Esta área foi contaminada em 14 de Outubro de 1983, por um derramamento de aproximadamente $3.500 \mathrm{~m}^{3}$ de petróleo de um dos oleodutos da Petrobrás, na altura do quilômetro 93 da rodovia Rio-Santos. Após o acidente, foram descritas a ocorrência de quedas de folhas, redução da área foliar e maior susceptibilidade ao ataque por herbívoros, reduzindo assim a taxa fotossintética do sistema (Ponte et al., 1987). A área foi caracterizada quanto às propriedades físico-químicas e mineralógicas do solo por Gamero (2001), a qual coletou amostras em 30 pontos (a cada $10 \mathrm{~m}$ ) apartir do Rio Iriri, de quatro camadas (0-10; 20-30; 40-50; e $60-80 \mathrm{~cm}$ ) em uma transeção de $300 \mathrm{~m}$ (Figura 1B, Tabela 1). O solo da área foi classificado como predominantemente ORGANOSSOLO TIOMÓRFICO, segundo o Sistema Brasileiro de Classificação de Solos (EMBRAPA, 1999). A análise mineralógica da fração argila apontou predominância de caulinita, seguida de montmorilonita, micas secundárias, pirita e quartzo. No solo há um equilíbrio geoquímico, onde elementos como $\mathrm{Fe}^{+2}$ e $\mathrm{S}^{0}$ encontram-se livres na solução, com certa estabilidade na forma de pirita $\left(\mathrm{FeS}_{2}\right)$ (Gamero, 2001). 

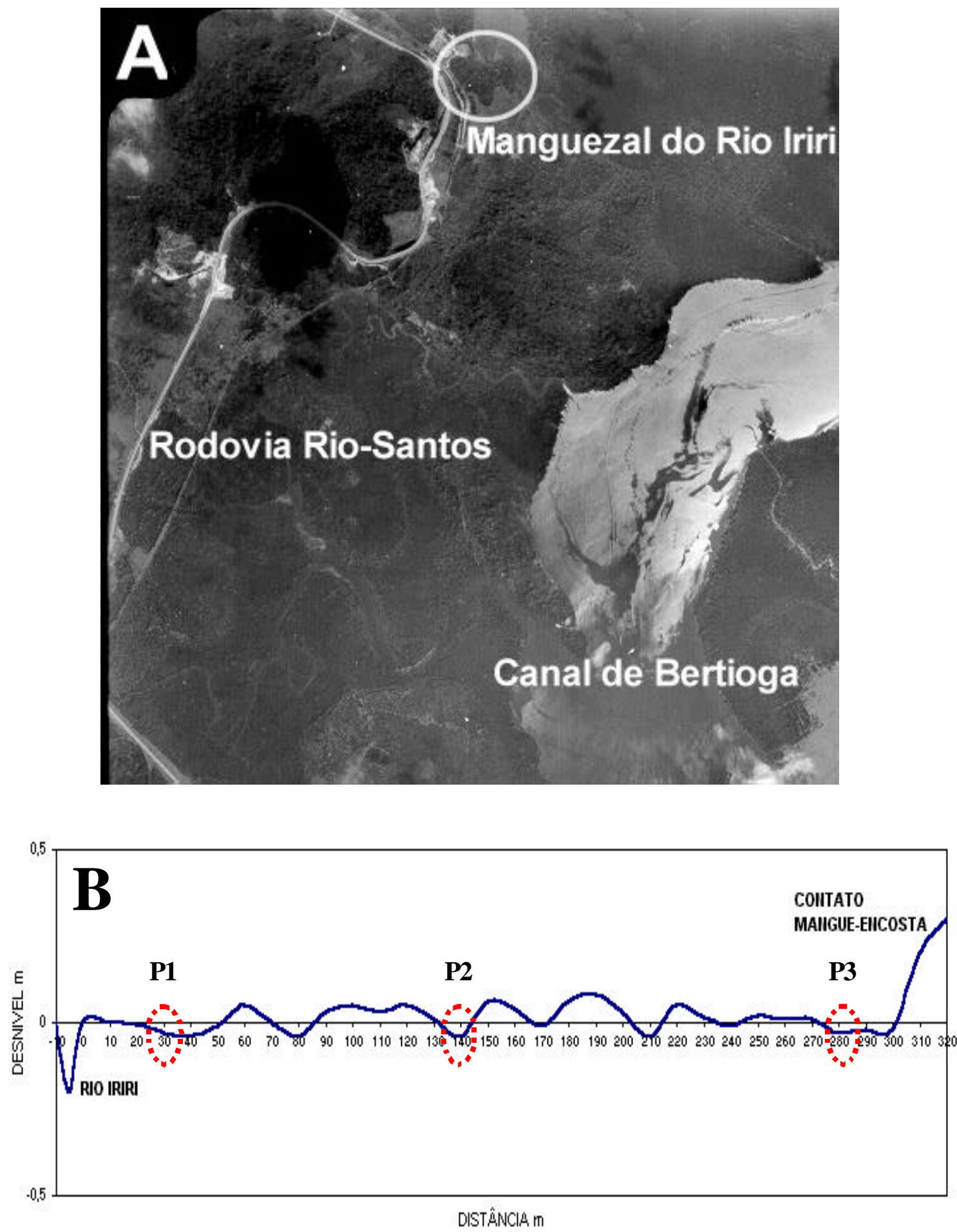

Figura 1 - Fotografia aérea da região de manguezais do canal de Bertioga (A) e corte topográfico da área do manguezal do rio Iriri, Santos, SP, contaminado com petróleo, utilizado para as coletas (B) (Fonte: Gamero 2001). 
Tabela 1. Análise física e química de amostras de solo de mangue contaminado com petróleo (Gamero, 2001).

\begin{tabular}{|c|c|c|c|c|c|c|c|c|c|c|c|c|c|c|c|c|}
\hline \multirow[b]{3}{*}{ Amostra } & \multicolumn{13}{|c|}{ Análise Química } & \multicolumn{3}{|c|}{ Granulometria } \\
\hline & \multirow{2}{*}{$\begin{array}{l}\text { M.O. } \\
\left(\mathrm{g} \mathrm{kg}^{-1}\right)\end{array}$} & \multirow{2}{*}{$\begin{array}{c}\mathrm{P} \\
\left(\mathrm{mg} \mathrm{kg}^{-1}\right)\end{array}$} & \multirow{2}{*}{$\begin{array}{c}\mathrm{Na} \\
\mathrm{meq}\end{array}$} & $\mathrm{K}$ & $\mathrm{Ca}$ & $\mathrm{Mg}$ & $\mathrm{Al}$ & $\mathrm{H}+\mathrm{Al}$ & SB & CTCe & CTC & V & $\mathrm{m}$ & Argila & Silte & Areia \\
\hline & & & & \multicolumn{8}{|c|}{ - } & \multicolumn{2}{|c|}{----- \% ---- } & \multicolumn{3}{|c|}{ 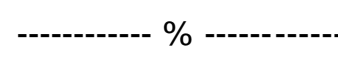 } \\
\hline \multicolumn{17}{|l|}{ G3 } \\
\hline $00-10 \mathrm{~cm}$ & 140 & 49 & 13,8 & 8,9 & 52,0 & 130,0 & 2,0 & 50,0 & 190 & 192,9 & 240,9 & 79 & 1 & 26,0 & 31,0 & 43,0 \\
\hline $20-30 \mathrm{~cm}$ & 240 & 18 & 9,43 & 8,5 & 41,0 & 80,0 & 7,0 & 101,0 & 129 & 136,5 & 230,5 & 56 & 5 & 22,3 & 26,4 & 51,2 \\
\hline $40-50 \mathrm{~cm}$ & 270 & 18 & 9,32 & 7,9 & 39,0 & 90,0 & 3,0 & 66,0 & 136 & 139,9 & 202,9 & 67 & 2 & 22,3 & 21,3 & 56,2 \\
\hline $60-80 \mathrm{~cm}$ & 54 & 73 & 14,19 & 14,6 & 140,0 & 140,0 & 1,0 & 10,0 & 294 & 295,6 & 304,6 & 97 & 1 & 55,2 & 24,5 & 20,1 \\
\hline \multicolumn{17}{|l|}{ G16 } \\
\hline $00-10 \mathrm{~cm}$ & 290 & 22 & 11,5 & 10,4 & 60,0 & 115,0 & 1,0 & 55,0 & 185 & 186,4 & 240,4 & 77 & 1 & 16,7 & 14,6 & 68,5 \\
\hline $20-30 \mathrm{~cm}$ & 140 & 10 & 8,86 & 5,9 & 36,0 & 70,0 & 1,0 & 57,0 & 111 & 112,9 & 168,9 & 66 & 1 & 12,5 & 14,6 & 72,8 \\
\hline $40-50 \mathrm{~cm}$ & 59 & 97 & 5,87 & 5,3 & 35,0 & 45,0 & 6,0 & 81,0 & 85 & 91,3 & 166,3 & 51 & 7 & 14,4 & 14,4 & 71,1 \\
\hline $60-80 \mathrm{~cm}$ & 64 & 33 & 7,82 & 7,7 & 107,0 & 75,0 & 3,0 & 75,0 & 189 & 192,7 & 264,7 & 72 & 2 & 28,9 & 18,6 & 52,3 \\
\hline \multicolumn{17}{|l|}{ G30 } \\
\hline $00-10 \mathrm{~cm}$ & 320 & 19 & 6,33 & 10,0 & 54,0 & 90,0 & 7,0 & 87,0 & 154 & 161,0 & 241,0 & 64 & 4 & 29,9 & 44,8 & 25,2 \\
\hline $20-30 \mathrm{~cm}$ & 340 & 28 & 7,13 & 8,7 & 47,0 & 95,0 & 3,0 & 71,0 & 150 & 153,7 & 221,7 & 68 & 2 & 31,2 & 41,7 & 27,0 \\
\hline $40-50 \mathrm{~cm}$ & 62 & 32 & 8,63 & 13,2 & 32,0 & 90,0 & 10,0 & 73,0 & 135 & 145,2 & 208,2 & 65 & 7 & 46,4 & 42,2 & 11,3 \\
\hline $60-80 \mathrm{~cm}$ & 34 & 35 & 10,93 & 13,7 & 26,0 & 90,0 & 18,0 & 72,0 & 129 & 147,7 & 201,7 & 64 & 12 & 38,0 & 29,5 & 32,4 \\
\hline
\end{tabular}


As amostras utilizadas neste trabalho foram coletadas nessa mesma transeção, entre o Rio Iriri e o início da área de mangue, no contato mangue-encosta. Foram coletadas amostras de 3 pontos: extremo próximo æ̀ margens do rio (P1), próximo ao local do derramamento (contato mangueencosta) (P3) e ponto intermediário entre P1 e P3 (P2) (Figura 1B). As amostras, analisadas por Gamero (2001) quanto æ̀ características físicoquímicas foram coletadas nos pontos: G3, a $30 \mathrm{~m}$ do início da transeção que coincide com o ponto P1 deste trabalho, e pontos G16, a $160 \mathrm{~m}$ do início da transeção e G30, a $300 \mathrm{~m}$ do início da transeção, que estão próximos aos pontos P2 e P3 deste trabalho, respectivamente (Figura 1B). Espera-se que a poluição remanescente seja maior em $\mathrm{P} 3$, diminuindo na direção de $\mathrm{P} 1$, devido à maior influência das correntes de fluxo e refluxo de maré, além da constatação visual da presença de petróleo em P2 e P3, o que não ocorre em P1. A detecção e quantificação dos hidrocarbonetos de petróleo remanescentes na área foram realizadas, nos pontos a $30 \mathrm{~m}, 160 \mathrm{~m}$ e $230 \mathrm{~m}$ do início da transeção, nas camadas de $0-10,20-30,40-50$ e $60-80 \mathrm{~cm}$ (dados não publicados). Não foram detectados hidrocarbonetos que indiquem persistência de petróleo próximo ao P1 deste trabalho, enquanto que próximo a P2 e P3, esses hidrocarbonetos foram detectados, e em maiores quantidades nas camadas de 0 a $30 \mathrm{~cm}$, apresentando variações na quantidade.

\subsection{Amostragem}

As amostras foram coletadas utilizando amostrador de aço inoxidável: um cilindro cortado longitudinalmente, com $100 \mathrm{~cm}$ de comprimento e $7 \mathrm{~cm}$ de diâmetro. As seções representando as camadas 0-5, 5-10, 10-15, 1520, 20-30, 30-40, 40-50, 50-60, 60-70, 70-80, 80-90 e 90-100 cm (com exceção do P3, onde foi possível coletar amostras até $80 \mathrm{~cm}$ ) foram separadas, acondicionadas em sacos plásticos, armazenadas em caixas térmicas com gelo 
e levadas imediatamente ao laboratório. Foram feitas 3 coletas aleatórias por ponto de amostragem.

Durante a amostragem foi determinado o valor de $\mathrm{pH}$ de cada amostra, utilizando-se um potenciômetro portátil (Mettler Toledo, MP120 pH Meter).

As subamostras utilizadas para as análises microbiológicas foram imediatamente separadas e conservadas em câmara fria a $4^{\circ} \mathrm{C}$, exceto as utilizadas para as análises de diversidade genética. Para essas análises, as subamostras foram acondicionadas em tubos esterilizados de polietileno de $1,5 \mathrm{~mL}$, congeladas em $\mathrm{N}^{-}$líquido e conservadas a $-80^{\circ} \mathrm{C}$, para posterior extração do DNA total. De cada subamostra foi retidada uma alíquota de $10 \mathrm{~g}$ para determinação da umidade, após secagem a $105^{\circ} \mathrm{C}$ por $24 \mathrm{~h}$.

\subsection{Análises}

\subsubsection{Número Mais Provável de Bactérias Heterotróficas Aeróbias (NMP)}

Das subamostras $0-5,5-10,10-15,15-20,20-30,30-50$ e 50$100 \mathrm{~cm}$, retirou-se uma slíquota de $10 \mathrm{~g}$ de solo, a qual foi adicionada a erlenmayers contendo $90 \mathrm{~mL}$ de solução salina ( $\mathrm{NaCl}$ 0,85\%) esterilizada. Estas suspensões foram dispersas por 10 minutos em agitador orbital (Tecnal TE420), a 200rpm, antes de se efetuar diluições seriais $\left(10^{-1}\right.$ a $\left.10^{-5}\right)$ em solução salina. Uma alíquota de $0,1 \mathrm{~mL}$ de cada diluição foi adicionada a tubos contendo $5 \mathrm{~mL}$ de meio NA (0,5\% de peptona; $0,3 \%$ de extrato de carne e $1 \%$ de $\mathrm{NaCl}$ ). Para cada diluição foram feitas 4 repetições. Esses tubos foram incubados a $28^{\circ} \mathrm{C}$ por $48 \mathrm{~h}$. Após o período de incubação, os tubos foram analisados quanto a presença ou ausência de crescimento microbiano (turbidez). A partir dos resultados obtidos foi estimado o número mais provável (NMP) de bactérias heterotróficas aeróbias, utilizando-se uma tabela de NMP (Andrade \& Hamakawa, 1994). 


\subsubsection{Biomassa Microbiana (C-biomassa)}

Das subamostras de $0-5,5-10,10-15,15-20,20-30,30-50$ e 50$100 \mathrm{~cm}$, retirou-se 2 alíquotas de $10 \mathrm{~g}$ de solo para determinação do $\mathrm{C}$ na biomassa microbiana (C-biomassa) pelo método da fumigação-extração (Vance et al., 1987). A primeira alíquota foi fumigada em dessecador contendo um becker com pérolas de vidro e clorofórmio. O clorofórmio foi evaporado sob vácuo. Após um período de $24 \mathrm{~h}$, procedeu-se a retirada do resíduo de clorofórmio do dessecador. A segunda alíquota serviu de controle (nãofumigada). Ambas alíquotas receberam, então, $40 \mathrm{~mL}^{\text {de } \mathrm{K}_{2} \mathrm{SO}_{4}} 0,5 \mathrm{~mol} \mathrm{~L}^{-1}$, e foram agitadas por 30 minutos. A suspensão resultante foi filtrada em papel de filtro Whatman $n^{0} 1$. O carbono orgânico dos extratos foi determinado pela digestão de $10 \mathrm{~mL}$ do filtrado com $1 \mathrm{~mL}$ de $\mathrm{K}_{2} \mathrm{Cr}_{2} \mathrm{O}_{7}$ e $10 \mathrm{~mL}$ de uma mistura de $\mathrm{H}_{2} \mathrm{SO}_{4}$ e $\mathrm{H}_{3} \mathrm{PO}_{4}$ concentrado (1:1, v:v), em erlenmayers de $50 \mathrm{~mL}$. Esta solução permaneceu aquecida em banho-maria a $90^{\circ} \mathrm{C}$ por 1 hora. Após serem resfriadas, as amostras receberam $10 \mathrm{~mL}$ de $\mathrm{H}_{2} \mathrm{O}$ desionizada. $\mathrm{O}$ excesso de $\mathrm{K}_{2} \mathrm{Cr}_{2} \mathrm{O}_{7}$ foi determinado por titulação com sulfato ferroso de amônio, utilizandose difenilamina sulfonato de bário como indicador. O C-biomassa foi calculada da seguinte forma:

C-biomassa $=2,64 \mathrm{Ec}$, sendo:

$\mathrm{Ec}=(\mathrm{C}$-orgânico extraído de solos fumigados) - (C-orgânico extraído de solos não-fumigados)

Os dados foram expressos em $\mu \mathrm{g}$ de $\mathrm{C} \mathrm{g}^{-1}$ de solo seco.

\subsubsection{Respiração Basal}

Das subamostras de $0-5,5-10,10-15,15-20,20-30,30-50$ e $50-$ $100 \mathrm{~cm}$, retirourse uma alíquota de $50 \mathrm{~g}$ de solo para determinação da respiração basal $(\mathrm{RB})$. Essa alíquota foi incubada em frasco de vidro provido de tampa vedante, contendo um frasco com $10 \mathrm{~mL}$ de solução de $\mathrm{NaOH} 0,5 \mathrm{~mol} \mathrm{~L}^{-}$ 
1, para absorver o $\mathrm{CO}_{2}$ liberado do solo. Após 24 horas de incubação a $28{ }^{\circ} \mathrm{C}$, retirou-se o frasco com a solução de $\mathrm{NaOH}$, e adicionou-se $1 \mathrm{~mL}$ de $\mathrm{BaCl}_{2}$ e 3 gotas do indicador fenoftaleína. A quantidade de $\mathrm{CO}_{2}$ liberado do solo foi determinada após titulação do excedente de $\mathrm{NaOH}$ com solução de $\mathrm{HCl}$ 0,5 mol $\mathrm{L}^{-1}$. Os resultados obtidos foram expressos em $\mu \mathrm{g}$ de $\mathrm{C}^{-} \mathrm{CO}_{2} \mathrm{~g}^{-1}$ solo seco hora 1 .

\subsubsection{Respiração Induzida pelo Substrato}

Das subamostras de $0-5,5-10,10-15,15-20,20-30,30-50$ e $50-$ $100 \mathrm{~cm}$, retirourse uma alíquota de $50 \mathrm{~g}$ de solo para determinação da respiração induzida pelo substrato (RIS). Às alíquotas de solo, adicionou-se 0,5\% (em massa) de glicose anidra. O solo foi incubado em frascos hermeticamente fechados, contendo um frasco com $10 \mathrm{~mL}$ de solução de $\mathrm{NaOH}$ $0,5 \mathrm{~mol} \mathrm{~L}^{-1}$, para absorver o $\mathrm{CO}_{2}$ liberado do solo. Após 24 horas de incubação a $28{ }^{\circ} \mathrm{C}$, retirou-se o frasco com a solução de $\mathrm{NaOH}$, e adicionou-se $1 \mathrm{~mL}$ de $\mathrm{BaCl}_{2}$ e 3 gotas do indicador fenoftaleína. A quantidade de $\mathrm{CO}_{2}$ liberada foi determinada por titulação do $\mathrm{NaOH}$ excedente com solução de $\mathrm{HCl} 0,5 \mathrm{~mol} \mathrm{~L}^{-1}$. Os resultados obtidos foram expressos em $\mu \mathrm{g}$ de $\mathrm{C}-\mathrm{CO}_{2} \mathrm{~g}^{-1}$ solo seco hora ${ }^{-1}$.

\subsubsection{Quociente Metabólico}

O quociente metabólico $\left(q \mathrm{CO}_{2}\right)$ foi calculado como a razão entre o $\mathrm{C}-\mathrm{CO}_{2}$ liberado pela respiração basal e o $\mathrm{C}$ na biomassa microbiana.

\subsubsection{Diversidade Metabólica}

Das subamostras de 0-5, 5-10, 10-15, 15-20 e 20-30 cm, retirouse uma alíquota de $10 \mathrm{~g}$ de solo, a qual foi adicionada a erlenmayer contendo $190 \mathrm{~mL}$ de uma solução salina ( $\mathrm{NaCl}$ 0,85\%) esterilizada. Essas suspensões 
foram, então, dispersas por 25 minutos em agitador orbital (Tecnal TE-420) a 200rpm. Após 4 minutos de decantação, o sobrenadante foi transferido para tubo esterilizado e centrifugado a $6.300 \mathrm{~g}$ por 20 minutos a $4^{\circ} \mathrm{C}$. O sobrenadante foi descartado e o pelete ressuspendido em $20 \mathrm{~mL}$ da solução salina. Após 2 horas de decantação, à temperatura ambiente, para remoção das partículas grosseiras, alíquotas de $120 \mu \mathrm{L}$ do sobrenadante, contendo $10^{3}$ a $10^{4}$ células por $\mathrm{mL}$, foram adicionadas às cavidades das microplacas Biolog ECO (Biolog Inc., Hayward, Califórnia). Para cada repetição utilizou-se uma microplaca. Cada microplaca Biolog contém 31 fontes de carbono, amplamente utilizadas por microrganismos do solo e similares àfontes de $\mathrm{C}$ encontradas normalmente nos solos (Tabela 2), em triplicata, e 1 cavidade sem nenhuma fonte de carbono (controle negativo com água), além do corante indicador tetrazólio violeta. As placas foram incubadas a $28^{\circ} \mathrm{C}$ por 48 horas. O crescimento microbiano, avaliado pelo aumento da absorbância, foi determinado por espectrofotometria a 590nm, utilizando-se um leitor de microplacas (Microplate Reader Benchmark, Biorad).

A utilização de uma fonte de C pela microbiota foi considerada positiva quando o índice de desenvolvimento da cor $\left(\mathrm{W}_{\mathrm{E}}\right)$ foi maior do que 100, de acordo com Ibekwe \& Kennedy (1998), sendo que:

$W_{E}=\left[\frac{\left(W_{A}-W_{0}\right)}{W_{0}}\right] \times 100$

Onde,

$W_{E}=$ índice de desenvolvimento da cor;

$\mathrm{W}_{\mathrm{A}}=$ absorbância de cada cavidade;

$\mathrm{W}_{\mathrm{O}}=$ absorbância da cavidade controle.

O Metabolismo Heterotrófico Médio (MHM), para cada fonte de carbono, foi calculado de acordo com Garland (1996). O Índice de Diversidade de Shannon $(H)$, que compreende tanto a riqueza de substratos como a 
Tabela 2. Fontes de carbono contidas nas microplacas Biolog. Categorização dos substratos de carbono de acordo com Insan (1997).

\begin{tabular}{ll}
\hline Categoria & Nome da fonte de Carbono \\
\hline Polímero & Glicogênio \\
& Tween 40 \\
& Tween 80 \\
& $\alpha$-Ciclodextrina \\
& D-Celobiose \\
Carboidrato & i-Eritritol \\
& $\alpha$-D-Lactose \\
& $\beta$-Metil-D-Glicosídeo \\
& D-Xilose \\
& D-Manitol \\
& N-Acetil-D-Glicosamina \\
& Ácido D-Galacturônico $\gamma$-Lactona \\
& Ácido $\gamma$-Hidroxibutírico \\
& Ácido Itacônico \\
& Ácido $\alpha$-Cetobutírico \\
Ácido Carboxílico-D-glicosamínico & Ácido D-Galacturônico \\
& Ácido D-Málico \\
& Éster Metílico do Ácido Pirúvico \\
& L-Serina \\
Aminoácido & L-Arginina \\
& L-Asparagina \\
& L-Fenilalanina \\
& L-Treonina \\
& Ácido Glicil-L-glutâmico \\
Fenólico & Ácido 2-Hidroxibenzóico \\
& Ácido 4-Hidroxibenzóico \\
& Feniletilanina \\
& Putrescina \\
& D,L- $\alpha$-Glicerol fosfato \\
& Glicose-1-fosfato \\
&
\end{tabular}


intensidade com que os substratos são usados pela microbiota, foi calculado de acordo com Zak et al.(1994), utilizando-se a equação:

$H=-\sum p_{i}\left(\ln p_{i}\right)$

Onde,

$\mathrm{H}=$ índice de diversidade de Shannon;

$\mathrm{p}_{\mathrm{i}}=$ razão entre a atividade de utilização de determinado substrato e a atividade de utilização de todos substratos.

A riqueza de substratos $\left(S_{S}\right)$ foi determinada através do número total de substratos utilizados $\left(\mathrm{W}_{\mathrm{E}}>100\right)$ pela comunidade microbiana do solo. $\mathrm{A}$ eqüitabilidade de substratos $(E)$, que mede a uniformidade de utilização de um substrato em relação ao número de substratos utilizados pela microbiota, foi calculada de acordo com a equação:

$$
E=\frac{H}{\ln S_{S}}
$$

Onde,

$E=$ equitabilidade;

$\mathrm{S}_{\mathrm{S}}=$ é a riqueza de substratos;

$\mathrm{H}=$ índice de diversidade de Shannon. 


\subsubsection{Diversidade Genética}

\subsubsection{Extração do DNA Total do Solo}

O DNA total do solo foi extraído de amostras compostas, obtidas com a mistura de quantidades iguais das três repetições das subamostras $0-5$, 5-10, 10-15, 15-20, 20-30, 30-40, 40-50, 50-60, 60-70, 70-80, 80-90, 90-100 cm (com exceção do $\mathrm{P} 3$, onde foi possível coletar amostras até $80 \mathrm{~cm}$ ). Para a extração do DNA, utilizou-se o kit FastDNA Spin for Soil (Bio101, Vista, Califórnia). Em microtubos contendo granada finamente moída, foi adicionado 0,5 g de solo, $978 \mu \mathrm{L}$ de tampão fosfato e $122 \mu \mathrm{L}$ de Tampão MT. Estes tubos foram agitados, horizontalmente, por $30 \mathrm{~s}$ a $4 \mathrm{~m} \mathrm{~s}^{-1}$, em um FP120 FastPrep Cell Disruptor (Bio101, Vista, Califórnia). Em seguida, centrifugou-se por 1 min a $13000 \mathrm{~g}$. O sobrenadante foi transferido para um tubo limpo. À essa solução adicionaram-se $250 \mu \mathrm{L}$ de Tampão PPS, agitando-se os tubos 10 vezes por inversão. Os tubos foram centrifugados por $10 \mathrm{~min}$ a $13000 \mathrm{~g}$ e o sobrenadante coletado e transferido para um microtubo limpo. Ao sobrenadante adicionou-se $1 \mathrm{~mL}$ de matriz de ligação, agitando-se os tubos durante 2 min por inversão. Em seguida os tubos foram incubados por 3 min, a matriz de ligação foi transferida para um filtro acoplado a um microtubo (Spin Filter, Bio101), e os tubos centrifugados por 2 min a $13000 \mathrm{~g}$. A matriz de ligação retida no filtro foi lavada com $500 \mu \mathrm{L}$ de uma solução de lavagem (SEWS), e o filtro centrifugado 2 vezes por 2 min a $13000 \mathrm{~g}$. Após 5 min de incubação à temperatura ambiente, foram adicionados $50 \mu \mathrm{L}$ de água ultrapura ao filtro e centrifugourse por 2 min a 13000g. O DNA puro foi recolhido em um tubo limpo e sua quantificação feita por densitometria, após eletroforese em gel de agarose 1,5\%-0,5xTBE (1xTBE: 44mM Tris-borato, $1 \mathrm{mM}$ EDTA pH 8,0), utilizando-se um densitômetro laser FluorImagem (Molecular Dynamics) e o programa Fragment Analysis (Molecular Dynamics). Como padrão de tamanho e quantidade de DNA foi utilizado o marcador de massa DNA Mass Ladder (Gibco). 


\subsubsection{PCR}

Para a amplificação de fragmentos específicos do rDNA 16S de Bacteria utilizou-se o seguinte conjunto de iniciadores: BA338fGC (5' GCCCGCCGCGCGCGGCGGGCGGGGCGGGGGCACGGACTCCTACGGGAG GCAGCAG 3') e UN518r (5' ATTACCGCGGCTGCTGG 3') (Ovreas et al., 1997). A amplificação foi feita em solução contendo: $2,5 \mu \mathrm{L}$ de tampão para PCR $10 \mathrm{X} ; 0,2 \mathrm{mM}$ dNTP; $3,0 \mathrm{mM} \mathrm{MgCl} 2 ; 1 \mathrm{U}$ de Taq DNA polimerase recombinante (Gibco); 10 ng de DNA total; 5 pmol de cada primer; água Milli-Q esterilizada para um volume final de $25 \mu \mathrm{L}$. A amplificação foi realizada em um termociclador (Mastercycler Gradient, Eppendorf), nas seguintes condições: $95^{\circ} \mathrm{C}$ por $5 \mathrm{~min} ; 30$ ciclos de $92^{\circ} \mathrm{C}$ por $1 \mathrm{~min}, 55^{\circ} \mathrm{C}$ por 1 min e $72^{\circ} \mathrm{C}$ por $1 \mathrm{~min}$; $72^{\circ} \mathrm{C}$ por 10 min.. O DNA foi adicionado após desnaturação inicial a $95^{\circ} \mathrm{C}$ por 10 min. A quantificação dos amplicons resultantes foi feita por densitometria, após eletroforese em gel de agarose 1,5\%-0,5xTBE, utilizando-se um densitômetro laser Fluorlmager (Molecular Dynamics) e o programa Fragment Analysis (Molecular Dynamics). Como padrão de tamanho e quantidade de DNA foi utilizado o mercador de massa DNA Mass Ladder (Gibco).

Para a amplificação inicial de fragmentos específicos do rDNA 16S

de Archaea utilizourse o seguinte conjunto de iniciadores: Arch21F (5' TTCYGGTTGATCCYGCCIGA 3') e Arch958R (5' YCCGGCGTTGA(I/C)TCCAA TT 3') (Moyer et al., 1998). Os amplicons resultantes desta amplificação foram utilizados como molde para uma nova amplificação com o seguinte conjunto de iniciadores: Arch340FGC ( 5' CGCCCGCCGCGCGCGGCGGGCGG GGCGGG GGCACGGGGGGCCCTACGGGGYGCASCAG 3') e Arch519R (5' TTACCGCG GCKGCTG 3') (Ovreas et al., 1997). As amplificações foram feitas em solução contendo: 2,5 $\mu \mathrm{L}$ de tampão para PCR $10 \mathrm{X} ; 0,2 \mathrm{mM}$ dNTP; 3,0 mM MgCl $2 ; 1 \mathrm{U}$ de Taq DNA polimerase recombinante (Gibco); $10 \mathrm{ng}$ de DNA; 5 pmol de cada primer; água Milli-Q esterilizada para um volume final de $25 \mu \mathrm{L}$. A reação foi realizada em um termociclador (Mastercycler Gradient, Eppendorf), nas 
seguintes condições: $95^{\circ} \mathrm{C}$ por 5 min, 30 ciclos de $95^{\circ} \mathrm{C}$ por $30 \mathrm{seg}, 53^{\circ} \mathrm{C}$ por 30 seg e $72^{\circ} \mathrm{C}$ por $1 \mathrm{~min} ; 72^{\circ} \mathrm{C}$ por $6 \mathrm{~min}$. O DNA foi adicionado após desnaturação inicial a $95^{\circ} \mathrm{C}$ por $10 \mathrm{~min}$. A quantificação dos amplicons resultantes foi feita como descrito acima.

Os amplicons do rDNA 165 de Bacteria e Archaea foram analisados por eletroforese em gel de poliacrilamida com gradiente desnaturante (DGGE).

\subsubsection{Análise dos Amplicons do rDNA 16S}

Os amplicons do rDNA 16S foram separados por eletroforese em gel de poliacrilamida com gradiente desnaturante. Os géis de acrilamida:bisacrilamida $(37,5: 1 ; \mathrm{m}: \mathrm{m}) 8 \%$, foram preparados com gradiente desnaturante variando de $15 \%$ a $55 \%$, usando duas soluções: uma solução desnaturante $100 \%$, contendo $7 \mathrm{M}$ uréia e $40 \%$ formamida e uma solução $0 \%$ sem uréia e formamida (Ovreas et al., 1997). A eletroforese foi feita a $60^{\circ} \mathrm{C} \mathrm{e}$ $200 \mathrm{~V}$ constantes, por $3 \mathrm{~h}$, em um sistema de eletroforese vertical DCode (BioRad), utilizando solução tampão 0,5X TAE (10 mM Tris-acetato, 0,5 mM EDTA pH 8,0). Após a eletroforese, o gel foi fixado em uma solução $10 \%$ de ácido acético glacial por 15 min. Em seguida, o gel foi lavado três vezes com água destilada, imerso em solução de metanol $50 \%$ por 15 minutos, lavado três vezes com água destilada e imerso em solução de SYBR-Green I (1:10000; v:v) (Molecular Probe, Eugene, Oregon) por 30 min. Após a coloração, o gel foi lavado três vezes com água destilada e analisado por densitometria, utilizandose 0 densitômetro laser Fluorlmager e o programa Fragment Analysis (Molecular Dynamics). 


\subsubsection{Análise da Diversidade Genética}

A riqueza de espécies $\left(S_{E}\right)$ foi determinada pelo número de amplicons presentes em cada amostra. A similaridade entre as estruturas de comunidades de Bacteria e Archaea foi determinada com base na presença ou ausência das bandas detectadas no gel. A análise de agrupamento hierárquico foi feita com o programa Systat 8.0, utilizando-se matrizes de similaridade geradas pelo método de concordância simples ("simple matching"), algoritmo de Wand e a distância euclidiana como unidade de medida.

\subsubsection{Análises Estatísticas}

Os dados de $\mathrm{pH}$, Umidade, C-Biomassa, Respiração, $\mathrm{qCO}_{2}$, Índice de Diversidade Metabólica $(H)$, Riqueza de substratos $\left(\mathrm{S}_{\mathrm{S}}\right)$, Equitabilidade $(\mathrm{E})$ e Metabolismo Heterotrófico Médio ( $\mathrm{MHM}$ ) foram submetidos à análise de variância $(p \leq 0,05)$. As comparações de médias foram feitas através do teste de Tukey $(p \leq 0,05)$, utilizando-se o pacote estatístico Systat 8.0. 


\section{RESULTADOS}

\subsection{Umidade e pH do Solo}

A umidade do solo apresentou diferença significativa apenas para o fator PONTO, não havendo efeito significativo do fator PROFUNDIDADE e nem interação entre os fatores PONTO e PROFUNDIDADE (Tabela 3). A umidade do solo foi em média 9,5\% maior em P3 do que em P1 e P2 ( $p \quad 0,01)$ (Figura 2).

Os valores de $\mathrm{pH}$, cujo valor médio no solo estudado foi de 5,9, não apresentaram diferenças significativas nos pontos ou profundidades avaliadas (Tabela 3).

\subsection{Número Mais Provável (NMP) de Bactérias Heterotróficas Aeróbias}

O NMP de bactérias heterotróficas aeróbias apresentou diferença significativa apenas para o fator PONTO, não havendo efeito significativo do fator PROFUNDIDADE e nem interação entre os fatores PONTO e PROFUNDIDADE (Tabela 3). O NMP de bactérias heterotróficas aeróbias no P3 foi 3,5 vezes maior do que no P1 e P2 ( $p \quad 0,01$ ) (Figura 3A).

\subsection{Biomassa Microbiana (C-Biomassa)}

Os valores de C-Biomassa apresentaram diferença significativa apenas para o fator PROFUNDIDADE, não havendo efeito significativo 
Tabela 3. Análise de variância das variáveis avaliadas nas amostras de solo de mangue contaminado com petróleo.

\begin{tabular}{|c|c|c|c|c|c|c|c|c|c|c|c|}
\hline \multirow{2}{*}{ Causa da Variação } & \multicolumn{11}{|c|}{ Variáveis } \\
\hline & $u$ & $\mathrm{pH}$ & CB & $\mathrm{RB}$ & RIS & $q \mathrm{CO}_{2}$ & NMP & $\mathrm{S}_{\mathrm{S}}$ & MHM & E & $\mathrm{H}$ \\
\hline Ponto & * & n.s. & n.s. & * & * & * & * & * & * & $\star \star *$ & n.s. \\
\hline Profundidade & n.s. & n.s. & * & * & ** & n.s. & n.s. & n.s. & n.s. & n.s. & * \\
\hline Ponto x Profundidade & n.s. & n.s. & n.s. & n.s. & $\star *$ & n.s. & n.s. & n.s. & ** & n.s. & n.s. \\
\hline C.V. (\%) & 7,89 & 3,66 & 24,65 & 47,08 & 35,39 & 41,53 & 9.81 & 14,01 & 8,41 & 45,00 & 1,14 \\
\hline
\end{tabular}

U: umidade do solo; pH: pH do solo; CB: Carbono da biomassa microbiana; RB: respiração basal; RIS: respiração induzida pelo substrato; $\mathrm{qCO}_{2}$ : quociente metabólico; NMP: número mais provável de bactérias heterotróficas aeróbias; $\mathrm{S}_{\mathrm{s}}$ : riqueza de substratos; $\mathrm{MHM}$ : metabolismo heterotrófico médio; $\mathrm{E}$ : equitabilidade; $\mathrm{H}$ : índice de diversidade de Shannon.

n.s. = não significativo $(P \quad 0,05)$

* significativo ( $p \quad 0,01)$

** significativo $(p \quad 0,05)$ 


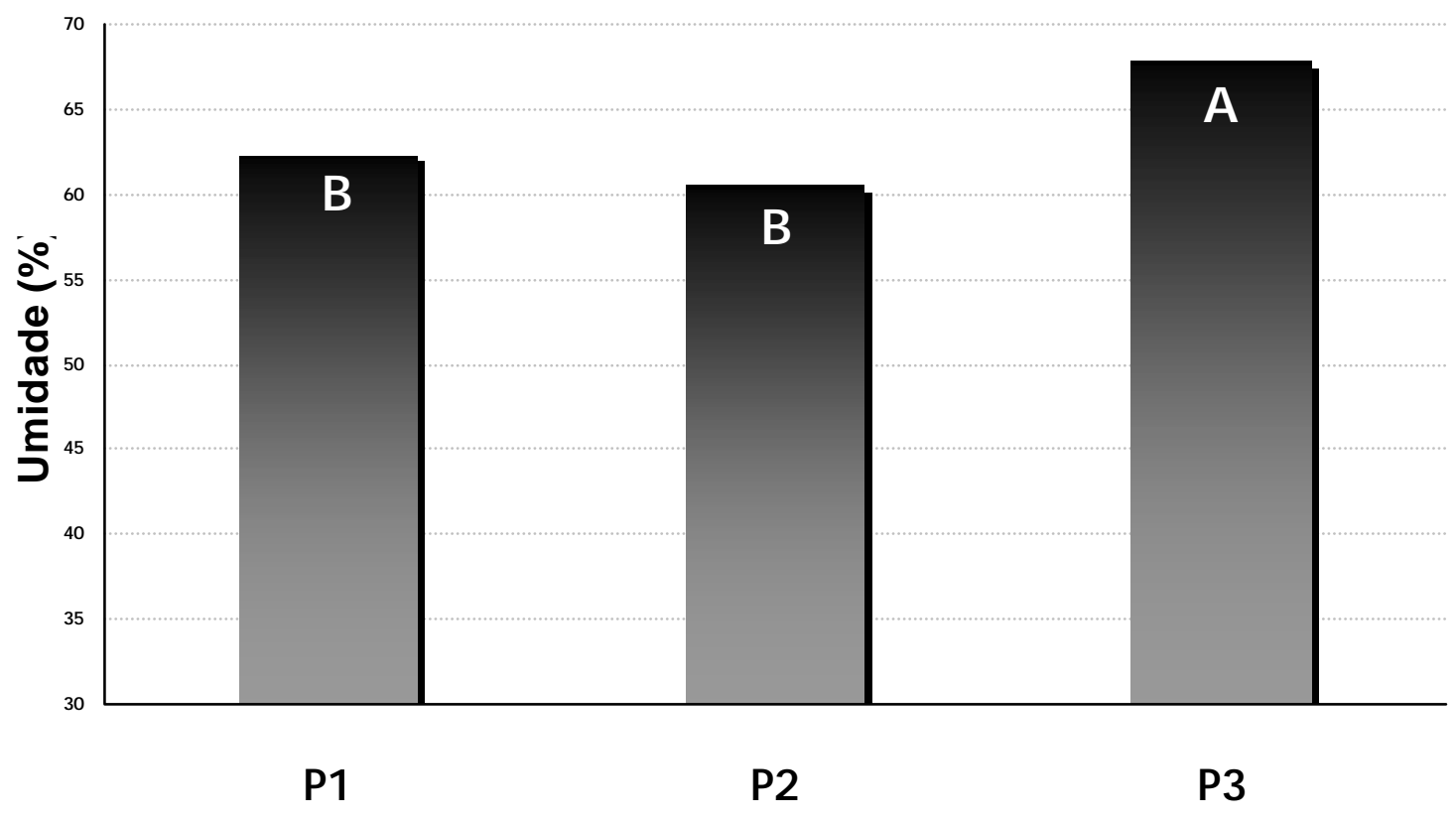

Figura 2 - Médias da umidade nas amostras de solo de mangue contaminado com petróleo. Letras distintas indicam diferença estatística significativa (Teste de Tukey, $\mathrm{p} \quad$ 0,01). 
do fator PONTO e nem interação entre os fatores PONTO e PROFUNDIDADE (Tabela 3). As amostras de 0 a $5 \mathrm{~cm}$ apresentaram valores de C-Biomassa estatisticamente diferentes ( $p \quad 0,01$ ) dos valores observados nas amostras de 20 a 30 e 30 a $50 \mathrm{~cm}$ (Figura 3B).

\subsection{Respiração Basal (RB)}

A RB do solo apresentou diferença significativa para os fatores PONTO e PROFUNDIDADE, não havendo interação entre estes (Tabela 3). O valor da RB no P3 foi em média 39\% maior do que em P1 e P2 (Figura 4A). Na comparação entre profundidades, as amostras de 50 a $100 \mathrm{~cm}$ apresentaram maior RB, diferindo estatisticamente das amostras de 5 a $30 \mathrm{~cm}(p \quad 0,01)$ (Figura 4B).

\subsection{Respiração Induzida pelo Substrato (RIS)}

A RIS apresentou diferenças significativas na interação entre os fatores PONTO e PROFUNDIDADE (Tabela 3). O P3 apresentou maior RIS do que P1 e P2 apenas na camada mais superficial (Tabela 4), onde foi encontrada a maior taxa de RIS dentre todas as amostras $\left(82,33 \mu \mathrm{g} \mathrm{C} \mathrm{g}^{-1}\right.$ solo $\mathrm{h}^{-1}$ ). Nas demais profundidades, P3 não difere de P1, mas é maior que P2 na amostra da profundidade de $5 \mathrm{a} 15 \mathrm{~cm}$. Não há diferença de RIS entre os pontos nas profundidades 15 a $20 \mathrm{~cm}$ e 50 a $100 \mathrm{~cm}$. A RIS de P2 não diferiu de $\mathrm{P} 1$ ou P3 em nenhuma profundidade. Dentro de cada ponto, a RIS não variou com a profundidade no P1 ou P2. Já no P3, há uma diminuição gradativa da RIS em função do aumento da profundidade, a qual difere estatisticamente ( $p \quad 0,01$ ) nas amostras de 15 a $100 \mathrm{~cm}$ quando comparada com as amostras de 0 a $5 \mathrm{~cm}$ (Tabela 4). 

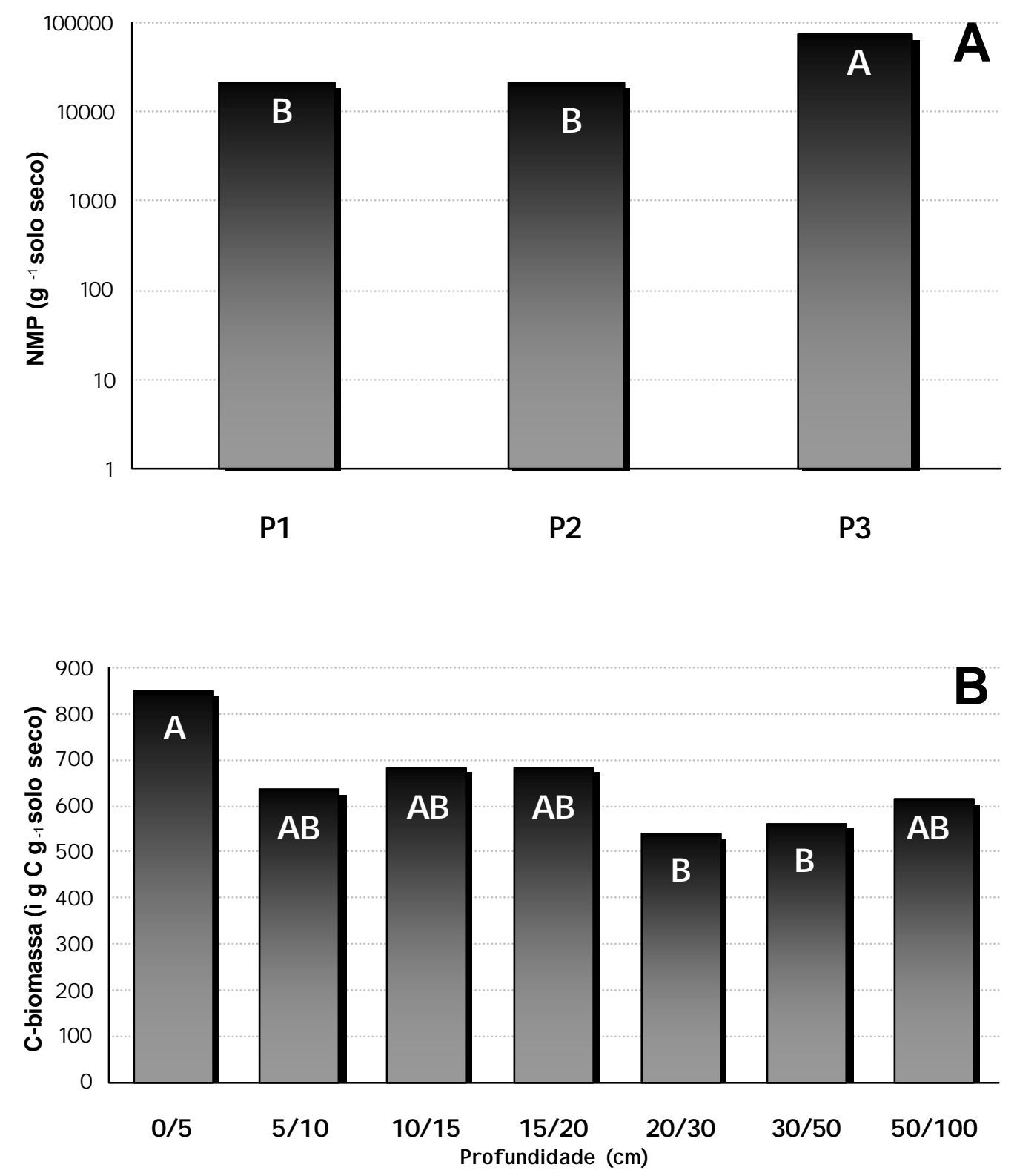

Figura 3 -Número mais provável de bactérias heterotróficas aeróbias (NMP) (A) e quantidade de carbono da biomassa microbiana (C-Biomassa) em solo de mangue contaminado com petróleo (B).

Letras distintas indicam diferença estatística significativa (Teste de Tukey, $\mathrm{p}$ 0,01). 

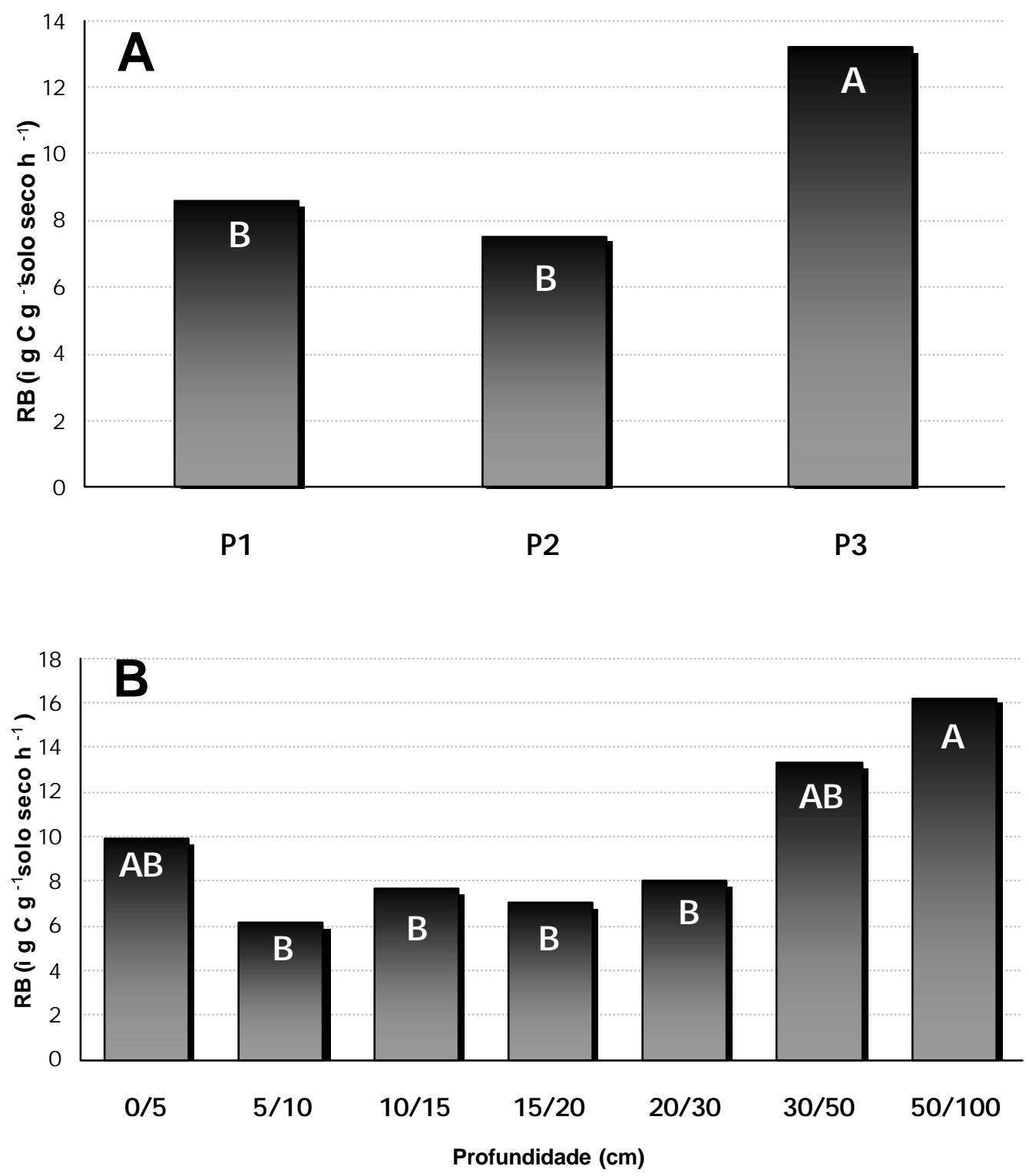

Figura 4 - Respiração Basal (RB) em diferentes pontos (A) e profundidades (B) de um solo de mangue contaminado com petróleo. Letras distintas indicam diferença estatística significativa (Teste de Tukey, $p \quad 0,01$ ). 
Tabela 4. Respiração induzida pelo substrato (RIS) em solo de mangue contaminado com petróleo.

\begin{tabular}{|c|c|c|c|}
\hline \multirow[b]{2}{*}{ Profundidade (cm) } & \multicolumn{3}{|c|}{ Ponto } \\
\hline & P1 & P2 & P3 \\
\hline & 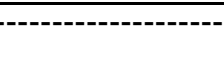 & $\mu \mathrm{g} \mathrm{C} \mathrm{g}^{-1}$ solo & - \\
\hline 0 a 5 & $45,00 \mathrm{~B} \mathrm{a}$ & $27,66 \mathrm{~B} \mathrm{a}$ & $82,33 \mathrm{~A}$ a \\
\hline 5 a 10 & $36,33 \mathrm{AB}$ a & $18,33 \mathrm{~B} \mathrm{a}$ & $56,66 \mathrm{~A} a b$ \\
\hline 10 a 15 & $56,66 \mathrm{~A}$ a & $23,00 \mathrm{~B} \mathrm{a}$ & $50,66 \mathrm{~A} \mathrm{ab}$ \\
\hline 15 a 20 & $44,66 \mathrm{~A}$ a & $31,00 \mathrm{~A} a$ & $40,66 \mathrm{~A} \mathrm{~b}$ \\
\hline 20 a 30 & $45,66 \mathrm{~A}$ a & $18,33 \mathrm{~B} \mathrm{a}$ & 38,33 AB b \\
\hline 30 a 50 & $56,00 \mathrm{~A}$ a & $15,66 \mathrm{~B} \mathrm{a}$ & $31,33 \mathrm{AB} b$ \\
\hline 50 a 100 & $38,33 \mathrm{~A} a$ & $18,00 \mathrm{~A} a$ & $32,00 \mathrm{~A} \mathrm{~b}$ \\
\hline
\end{tabular}

Letras maiúsculas são usadas para comparar as médias entre os Pontos, para a mesma Profundidade. Letras minúsculas são usadas para comparar as médias entre Profundidades, para o mesmo Ponto. Letras iguais não diferem estatisticamente (Teste de Tukey, p 0,05). 


\subsection{Quociente Metabólico $\left(q \mathrm{CO}_{2}\right)$}

$\mathrm{O} \mathrm{qCO}_{2}$ apresentou diferença significativa apenas para $\mathrm{o}$ fator PONTO, não havendo efeito significativo do fator PROFUNDIDADE e nem interação entre os fatores PONTO e PROFUNDIDADE (Tabela 3). O qCO2 foi em média 45\% menor em P2 do que em P1 e P3 ( $p \quad 0,01)$ (Figura 5).

\subsection{Diversidade Metabólica}

A riqueza de substratos de carbono $\left(\mathrm{S}_{\mathrm{S}}\right)$ apresentou diferença significativa apenas para o fator PONTO, não havendo efeito significativo do fator PROFUNDIDADE e nem interação entre os fatores PONTO e PROFUNDIDADE (Tabela 3). O maior valor de $S_{S}$ foi encontrado no P3, diferindo estatisticamente de P2 ( $p \quad 0,01$ ), enquanto P1 apresentou um valor intermediário de $\mathrm{S}_{S}$ (Figura $6 \mathrm{~A}$ ).

A equitabilidade de utilização dos substratos de $C(E)$ apresentou diferença significativa apenas para o fator PONTO, não havendo efeito significativo do fator PROFUNDIDADE e nem interação entre os fatores PONTO e PROFUNDIDADE (Tabela 3). O E foi maior no P1, o qual diferiu estatisticamente do P3 ( $p$ 0,05), mas foi estatisticamente igual em P2 (Figura $6 B)$.

Os valores de diversidade metabólica, medidos através do índice de diversidade de Shannon $(H)$, apresentaram diferença significativa apenas para o fator PROFUNDIDADE, não havendo efeito significativo do fator PONTO e nem interação entre os fatores PONTO e PROFUNDIDADE (Tabela 3). Houve um decréscimo gradativo do da diversidade metabólica em função do aumento da profundidade (Figura $6 \mathrm{C}$ ). 


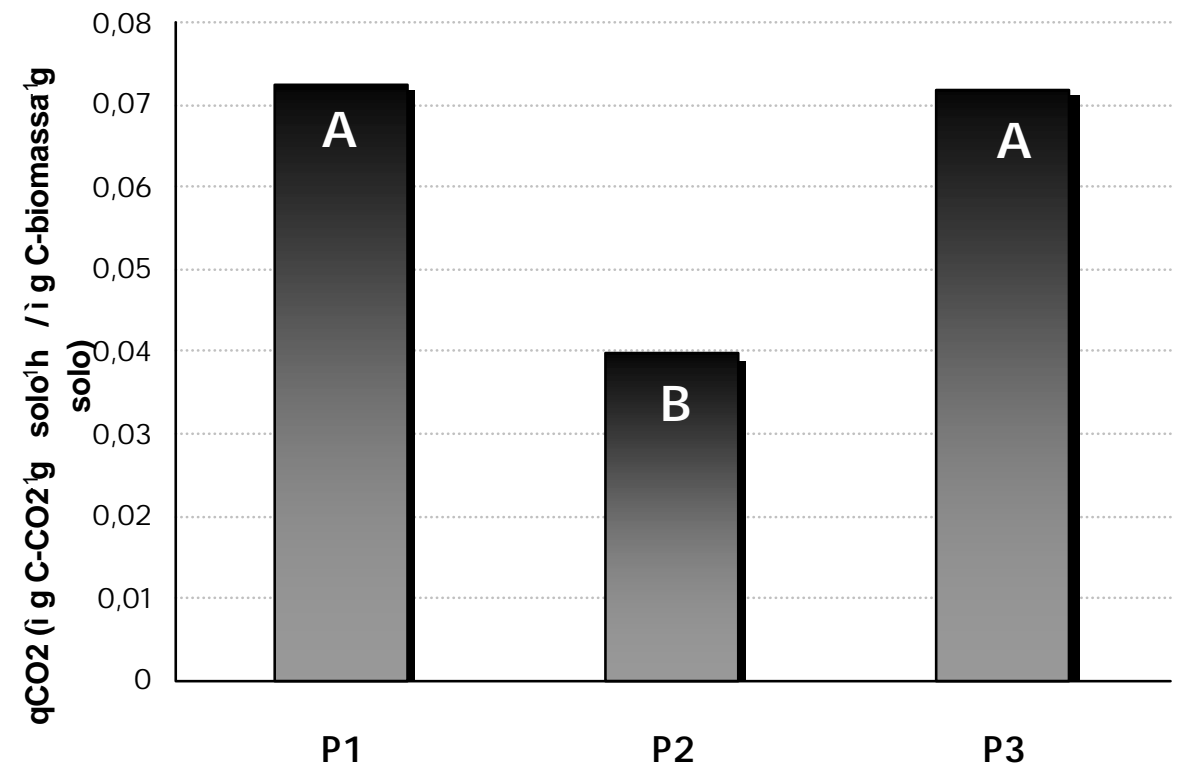

Figura 5 - Quociente metabólico $\left(q \mathrm{CO}_{2}\right)$ em solo de mangue contaminado com petróleo. Letras distintas indicam diferença estatística significativa (Teste de Tukey $\mathrm{p} \quad 0,01$ ). 

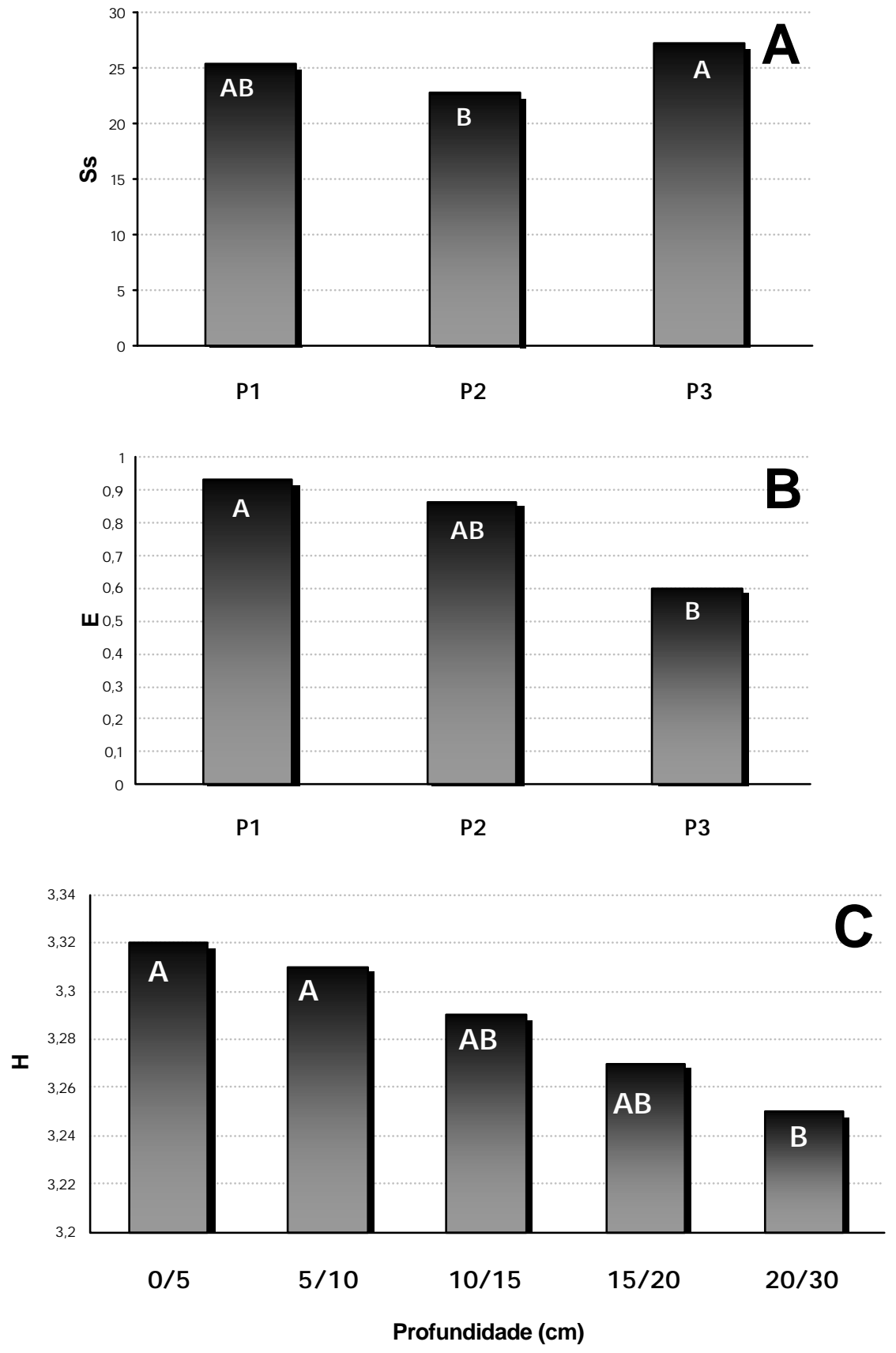

Figura 6 - Riqueza de substratos de carbono $\left(\mathrm{S}_{\mathrm{S}}\right)(\mathbf{A})$, equitabilidade $(\mathbf{B})$ e índice de diversidade de Shannon $(\mathrm{H})(\mathbf{C})$, com base na capacidade de utilização de substratos de carbono pelos microrganismos em solo de mangue contaminado com petróleo. Letras distintas indicam diferença estatística significativa (Teste de Tukey: $\mathrm{p} \quad 0,01\left(\mathrm{~S}_{\mathrm{S}}\right.$ e H) e p $\quad 0,05(\mathrm{E})$ ). 
O metabolismo heterotrófico médio (MHM) apresentou diferenças significativas na interação entre os fatores PONTO e PROFUNDIDADE (Tabela 3). Na camada mais superficial, o MHM foi maior em P3 do que em P2, mas não diferiu de P1 (Tabela 5). Na profundidade de 5 a 10cm, o MHM em P2 foi menor que em P1 e P3 ( $p$ 0,05). Apartir dos $10 \mathrm{~cm}, \mathrm{n}$ ão há diferença significativa entre o MHM dos 3 pontos. $O$ efeito da profundidade só foi observado em P2, onde o MHM foi maior na camada de 15 a $20 \mathrm{~cm}$ do que 0 a $5 \mathrm{~cm}$ (Tabela 5).

Foi elaborado um diagrama para possibilitar a visualização da intensidade de utilização de cada substrato de C pelos microrganismos das amostras de solo (Figura 7). Apenas dois substratos não foram utilizados em nenhum momento pelos microrganismos presentes no solo de mangue: ácido 2hidroxibenzóico e ácido $\alpha$-cetobutírico. Alta similaridade entre os perfis de utilização de substratos de $C$ nos diferentes pontos e profundidades pôde ser observada (Figura 7). A utilização do ácido itacônico foi maior no ponto P3, quando comparado com P1 e P2. A utilização de L-fenilalanina foi maior nas camadas mais superficiais de P3, quando comparada com as demais amostras. (Figura 7).

\subsection{Diversidade Genética}

As Figuras 8 e 9 mostram a separação dos amplicons do rDNA $16 S$ de Bacteria e Archaea, respectivamente, por DGGE. Estes géis foram analisados por densitometria e foi determinada, para cada amostra, a riqueza de espécies $\left(\mathrm{S}_{\mathrm{E}}\right)$, representada pelo número total de diferentes bandas (genótipos) detectadas.

Existe uma grande variação na distribuição das 41 bandas de Bacteria encontradas (Figura 10). A banda 18 é a única presente em todas as amostras. Já as bandas 1, 4, 13 e 41 ocorrem uma única vez. 
Tabela 5. Metabolismo heterotrófico médio de microrganismos de solo de mangue contaminado com petróleo.

\begin{tabular}{cccc}
\hline & \multicolumn{3}{c}{ Ponto } \\
Profundidade $(\mathbf{c m})$ & $\mathbf{P 1}$ & $\mathbf{P 2}$ & P3 \\
\hline $\mathbf{0}$ a $\mathbf{5}$ & $1,21 \mathrm{AB} \mathrm{a}$ & $1,11 \mathrm{~B} \mathrm{~b}$ & $1,35 \mathrm{~A} \mathrm{ab}$ \\
$\mathbf{5}$ a $\mathbf{1 0}$ & $1,32 \mathrm{~A} \mathrm{a}$ & $1,08 \mathrm{~B} \mathrm{~b}$ & $1,48 \mathrm{~A} \mathrm{a}$ \\
$\mathbf{1 0}$ a $\mathbf{1 5}$ & $1,24 \mathrm{~A} \mathrm{a}$ & $1,12 \mathrm{~A} \mathrm{ab}$ & $1,19 \mathrm{~A} \mathrm{~b}$ \\
$\mathbf{1 5}$ a $\mathbf{2 0}$ & $1,22 \mathrm{~A} \mathrm{a}$ & $1,36 \mathrm{~A}$ a & $1,27 \mathrm{~A}$ ab \\
$\mathbf{2 0}$ a $\mathbf{3 0}$ & $1,24 \mathrm{~A} \mathrm{a}$ & $1,15 \mathrm{~A}$ ab & $1,34 \mathrm{~A}$ ab
\end{tabular}

Letras maiúsculas são usadas para comparar as médias entre os Pontos, para a mesma Profundidade. Letras minúsculas são usadas para comparar as médias entre Profundidades, para o mesmo Ponto. Letras iguais não diferem estatisticamente (Teste de Tukey, $p \quad 0,05$ ). 


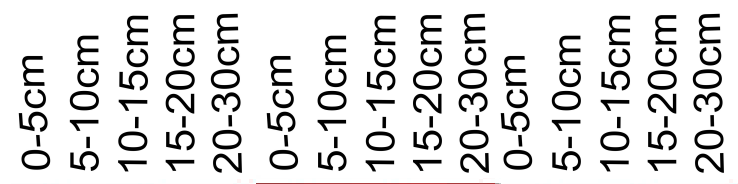

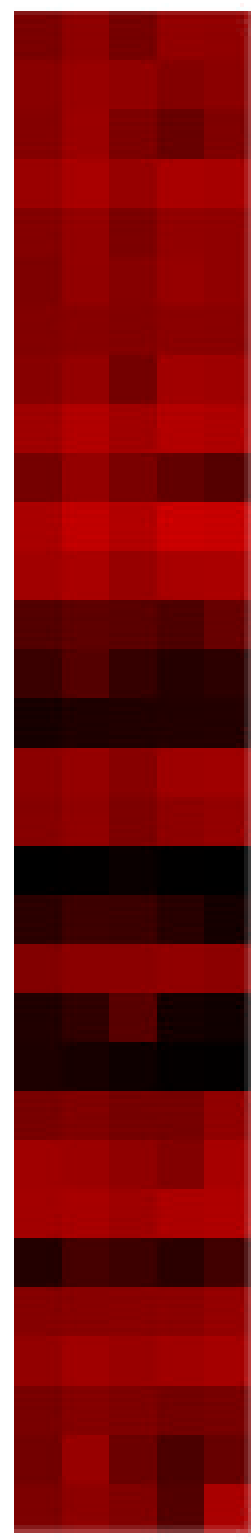

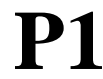

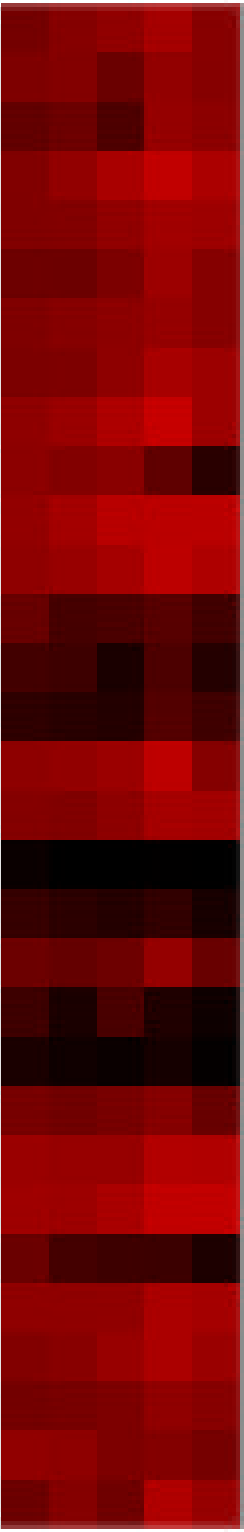

P2

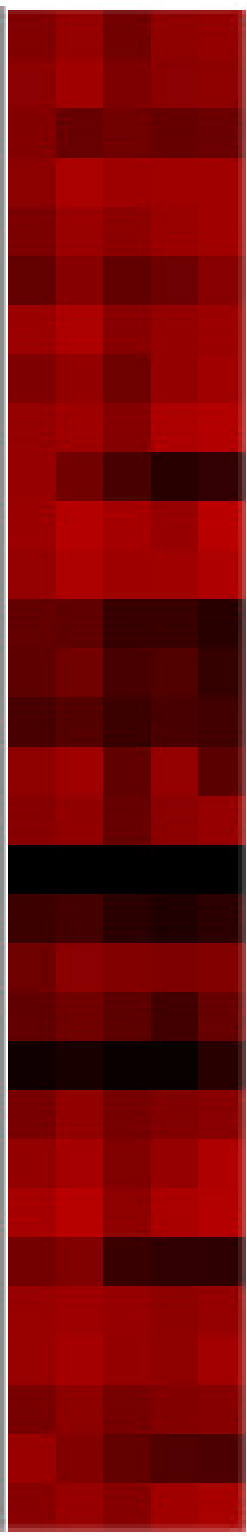

Èster Metílico do Ácido Pirúvico

Tween 40

Tween 80

$\alpha$ Ciclodextrina

Glicogênio

D-Celobiose

$\propto$ D-Lactose

$\beta$-Metil-D-Glicosídeo

D-Xilose

i-Erithritol

D-Manitol

$N$-Acetil-D-Glicosamina

Ácido-D-glicosamínico

Glicose-1-fosfato

$D, L$-o-Glicerol fosfato

Ácido D-Galacturônico $\gamma$-Lactona Ácido D-Galacturônico

Ácido 2-Hidroxibenzóico

Ácido 4-Hidroxibenzóico

Ácido $\gamma$ Hidroxibutírico

Ácido Itacônico

Ácido $\alpha$-Cetobutírico

Ácido D-Málico

L-Arginina

L-Asparagina

L-Fenil alanina

L-Serina

L-Treonina

Ácido Glicil-L-glutâmico

Fenil etilanina

Putrescina

Figura 7 - Níveis de utilização de 31 substratos de C por microrganismos de solo de mangue contaminado com petróleo. A intensidade de coloração vermelha é diretamente proporcional à utilização do substrato de Carbono. 
Profundidade $(\mathrm{cm})$

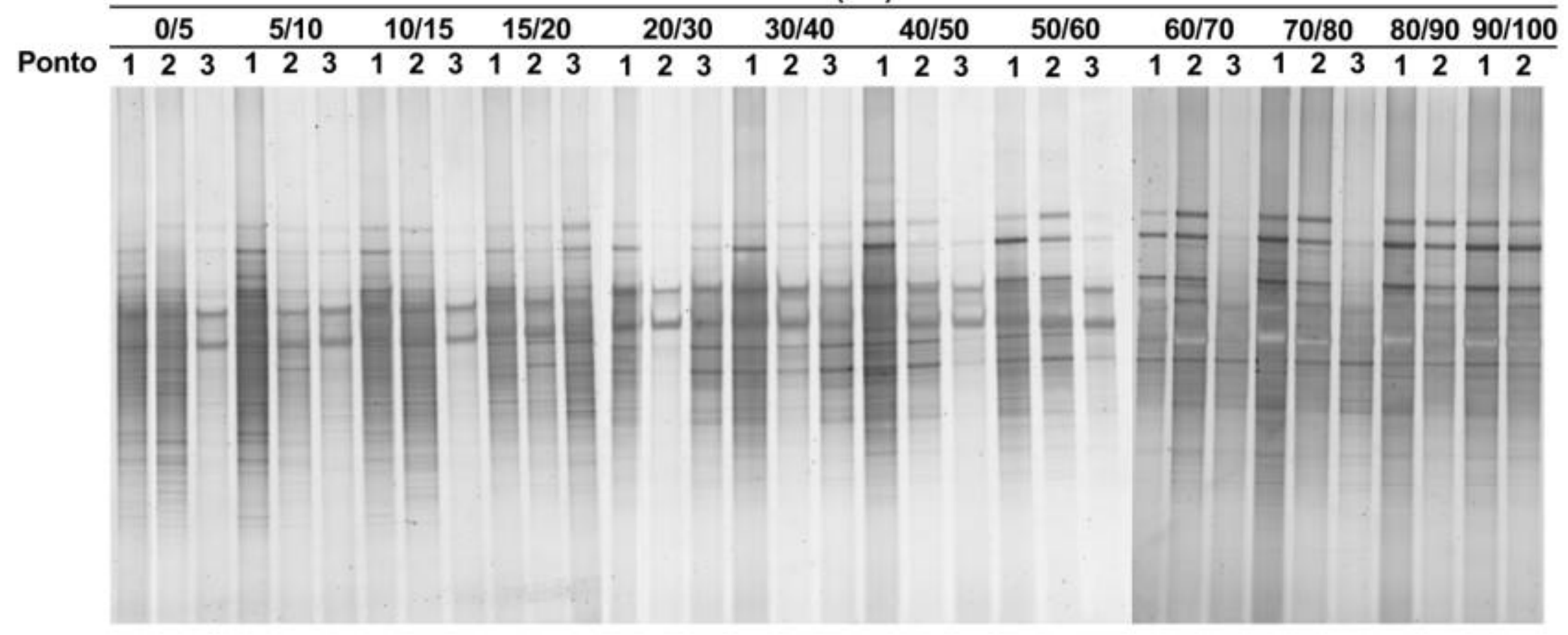

Figura 8 - DGGE de amplicons de Bacteria de solo de mangue contaminado com petróleo. 


\section{Profundidade $(\mathrm{cm})$}

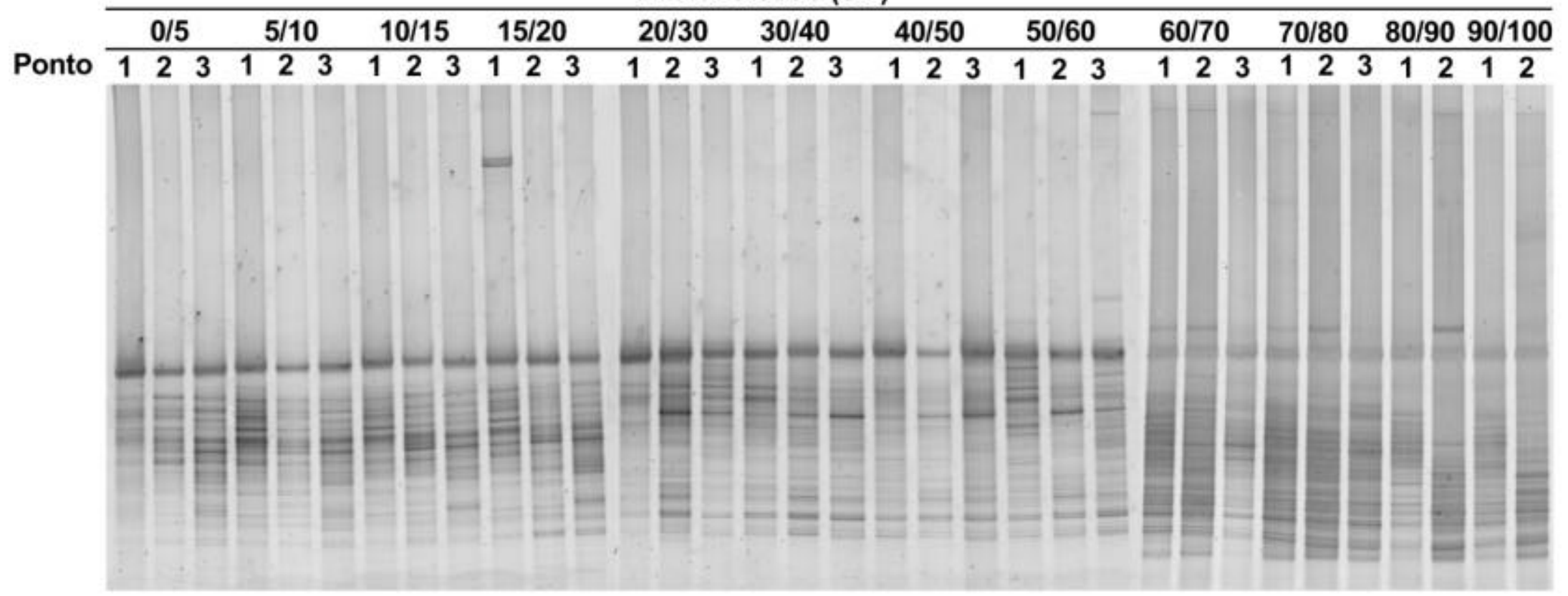

Figura 9- DGGE de amplicons de Archaea de solo de mangue contaminado com petróleo. 
A ocorrência de algumas bandas está relacionada aos fatores Ponto e/ou Profundidade. A banda 12, por exemplo, ocorre apenas em P1 e P2 nas amostras até $15 \mathrm{~cm}$, estando ausente nas demais amostras. A amostra de 0 a $5 \mathrm{~cm}$ do P2 foi a que apresentou o maior valor de $S_{E}$, contendo $85 \%$ das 41 bandas detectadas, enquanto as amostras de 40 a $50 \mathrm{~cm}$ do P3 apresentaram os menores valores, contendo respectivamente, $15 \%$ e $17 \%$ das 41 bandas detectadas (Figura 10).

As variações também são grandes na distribuição das 39 bandas de Archaea detectadas no solo (Figura 11). As bandas 8, 35 e 36 estão presentes em todas as amostras. Já as bandas 4, 5, 6 e 38 ocorrem uma única vez. As bandas 1 e 39 só ocorrem apartir de $60 \mathrm{~cm}$ de profundidade. A amostra de 60 a $70 \mathrm{~cm}$ do $P 2$ foi a que apresentou o maior valor de $S_{E}$, contendo $77 \%$ das 39 bandas detectadas, enquanto a amostra de 20 a $30 \mathrm{~cm}$ do P1 apresentou o menor valor de $\mathrm{S}_{\mathrm{E}}$, contendo $28 \%$ das 39 bandas detectadas (Figura 11).

A Figura 12 mostra a distribuição das bandas em função do fator PONTO. Os valores de $S_{E}$ de Bacteria e Archaea no P3 são menores do que nos outros dois pontos. A Figura 13 mostra a distribuição das bandas em função do fator PROFUNDIDADE. Os valores de $S_{E}$ de Bacteria e Archaea em função do fator PROFUNDIDADE apresentam comportamentos distintos. Para Bacteria, foi observada uma tendência de diminuição do valor de $S_{E}$ em função do aumento da profundidade, destacando-se a diminuição transiente nas profundidades de 20 a $40 \mathrm{~cm}$, que apresentaram ocorrência de $56 \%$ das bandas encontradas, contra $73 \%$ e $68 \%$ para as profundidades de 15 a $20 \mathrm{~cm}$ e 50 a $60 \mathrm{~cm}$ respectivamente (Figura $13^{A}$ ). Já para Archaea, a tendência é de uma elevação do percentual de bandas observadas, em função do aumento da profundidade, até $80 \mathrm{~cm}$ (Figura 13B).

$A$ variação dos valores de $S_{E}$ de Bacteria e Archaea em cada ponto, em função da profundidade, pode ser melhor visualizada na Figura 14. 
A análise de agrupamento hierárquico, em função da presença ou ausência das bandas detectadas em cada amostra, é mostrada nos dendrogramas das figuras 15 e 16 para Bacteria e Archaea, respectivamente. As amostras tenderam a um agrupamento em função do fator PONTO para Bacteria e em função do fator PROFUNDIDADE para Archaea. 


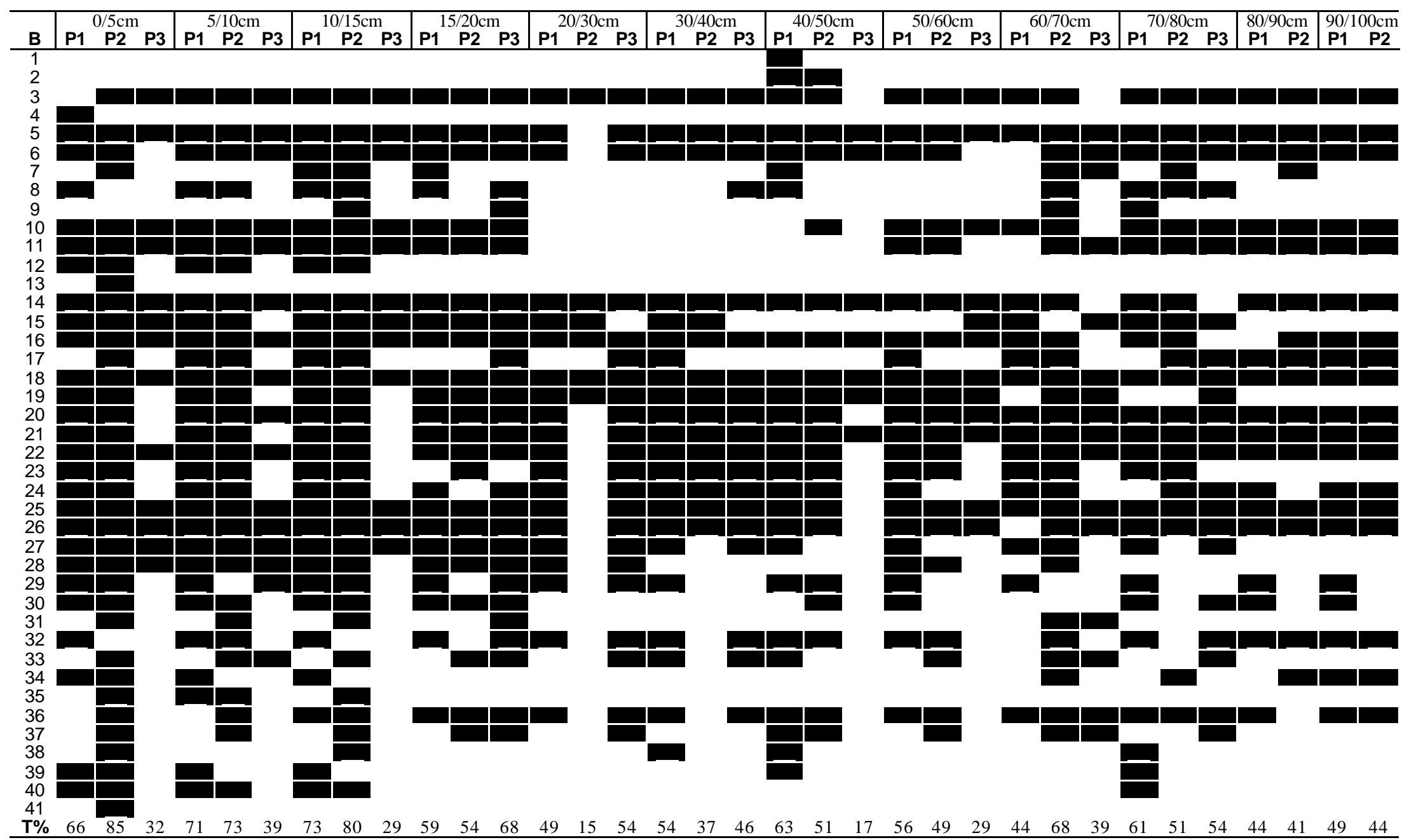

Figura 10 - Diagrama representando as bandas de rDNA $16 \mathrm{~S}$ do domínio Bactéria de comunidades de solo de mangue contaminado com petróleo, detectadas por DGGE. : presença da banda, : ausência da banda. T\% = porcentagem de bandas presentes na amostra em relação às 41 bandas encontradas. 


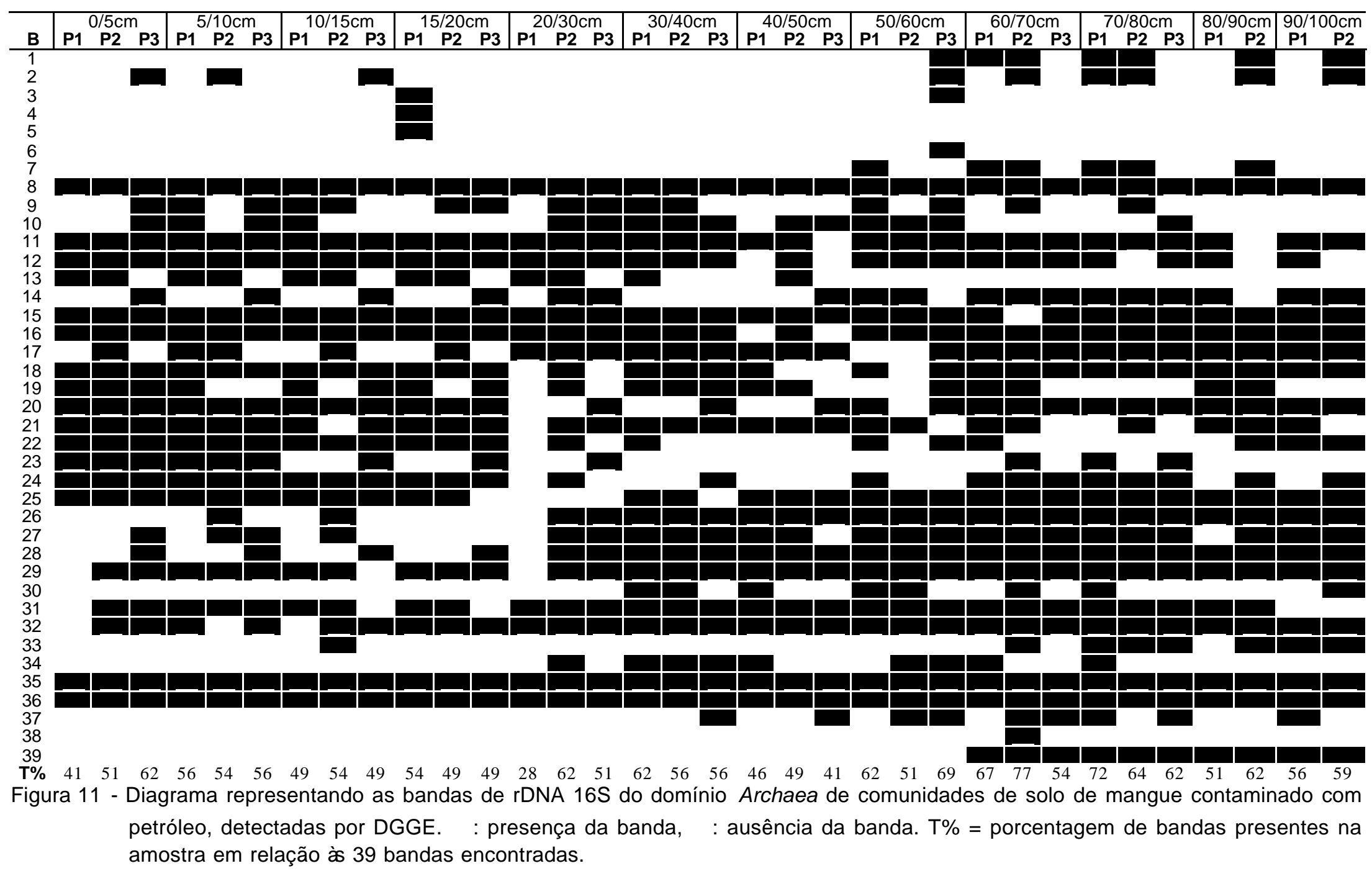




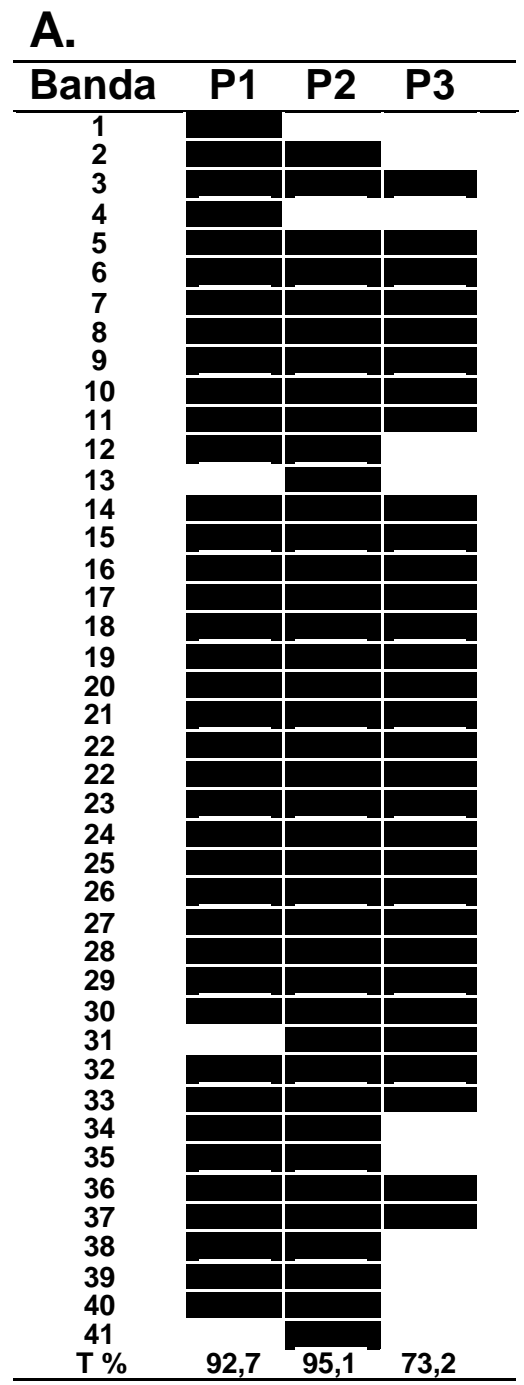

B.

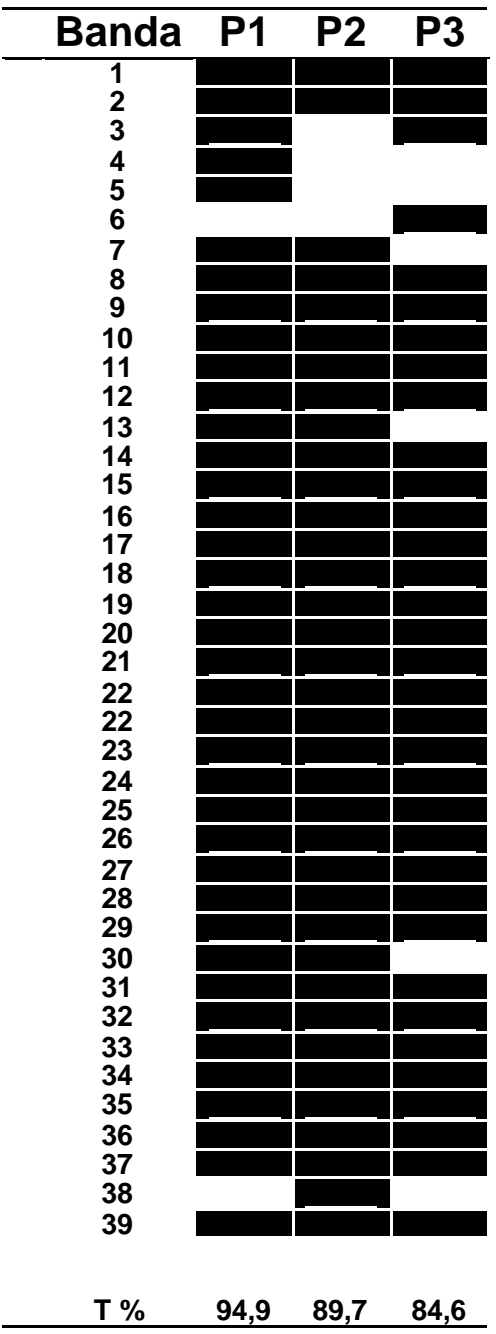

Figura 12 - Diagrama representando as bandas de rDNA 16S dos domínios Bactéria (A) e Archaea (B) de solo de mangue contaminado com petróleo, detectadas por DGGE. Para a ocorrência da banda no ponto, foi considerada a detecção da mesma pelo menos numa profundidade. : presença da banda, : ausência da banda. $\mathrm{T} \%=$ porcentagem de bandas presentes na amostra em relação ao total de bandas encontradas para cada domínio. 
A
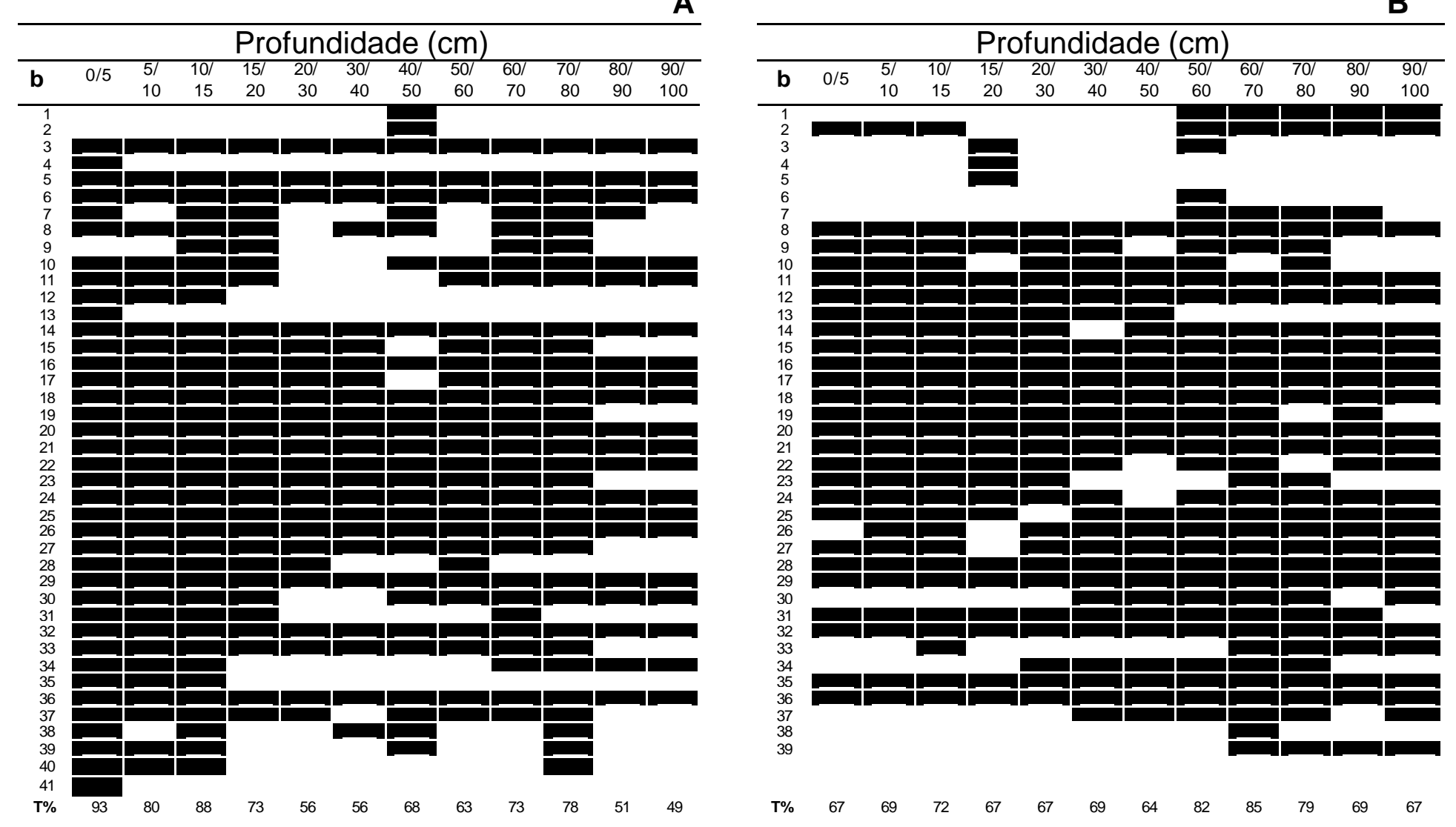

Figura 13 - Diagrama representando as bandas de rDNA 16S dos domínios Bactéria (A) e Archaea (B), de comunidades de solo de mangue contaminado com petróleo, detectadas por DGGE. Para a ocorrência da banda na profundidade, foi considerada pelo menos uma ocorrência da banda em qualquer ponto da mesma. $\mathrm{b}=$ número da banda = presença da banda, = ausência da banda. $\mathrm{T} \%=$ porcentagem de bandas presentes na amostra em relação ao total de bandas encontradas para cada domínio. 

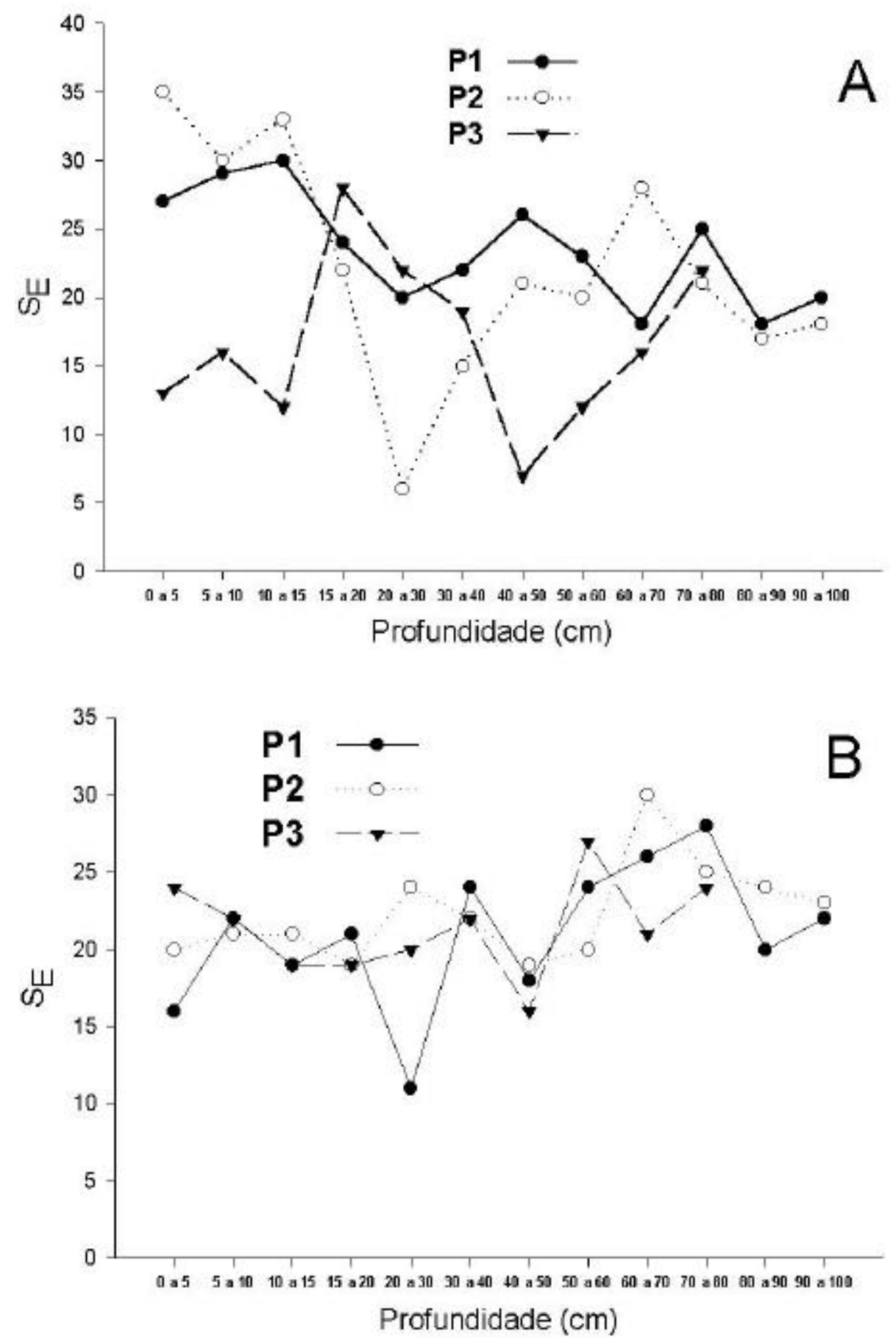

Figura 14 - Variação da Riqueza de Espécies $\left(\mathrm{S}_{\mathrm{E}}\right)$ de microrganismos do domínio Bactéria (A) e Archaea (B) detectados em solo de mangue contaminado com petróleo, por DGGE. 


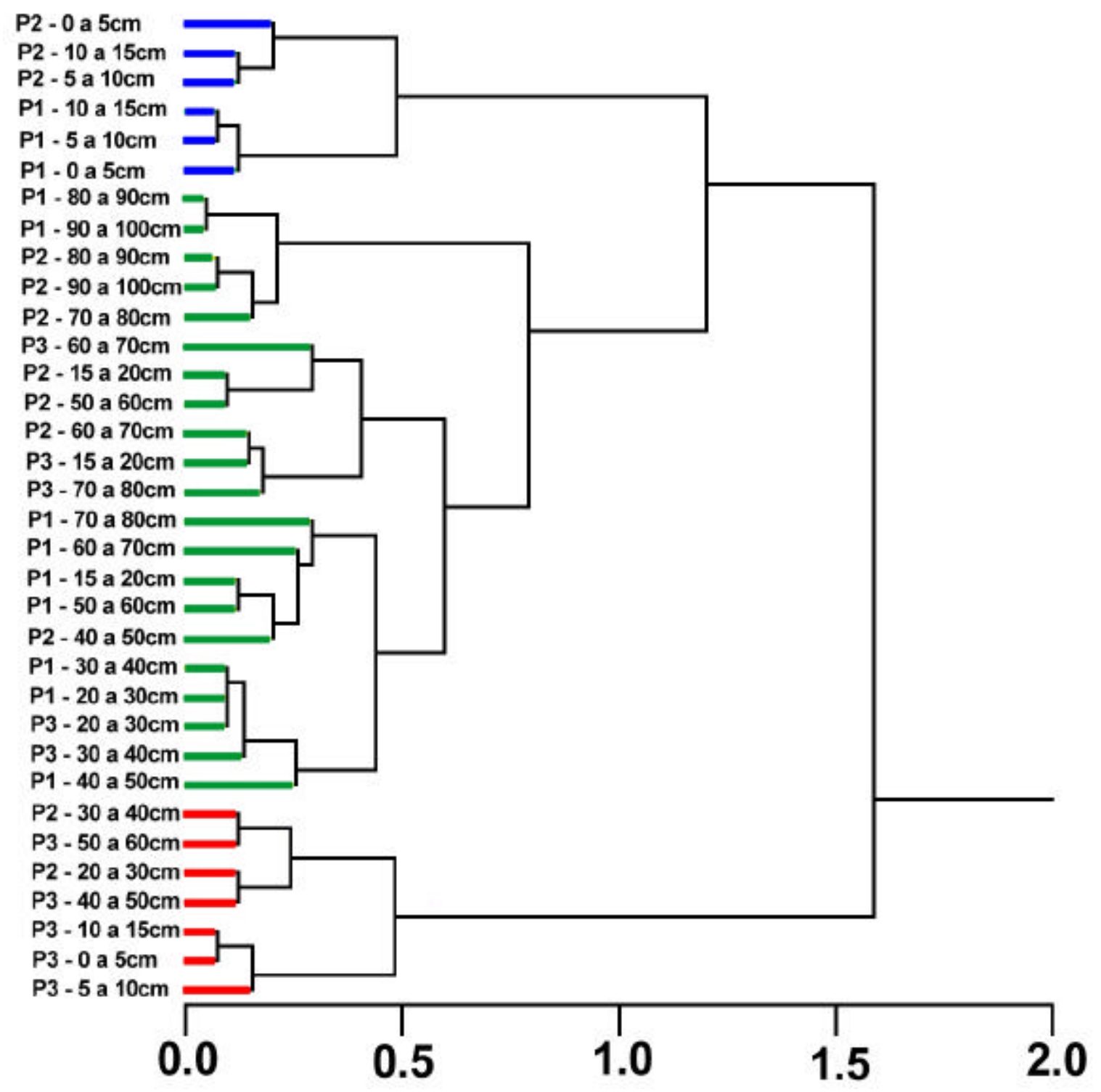

Figura 15 - Agrupamento hierárquico de amplicons de rDNA 16S de Bacteria de solo de mangue contaminado com petróleo, detectadas por DGGE. 


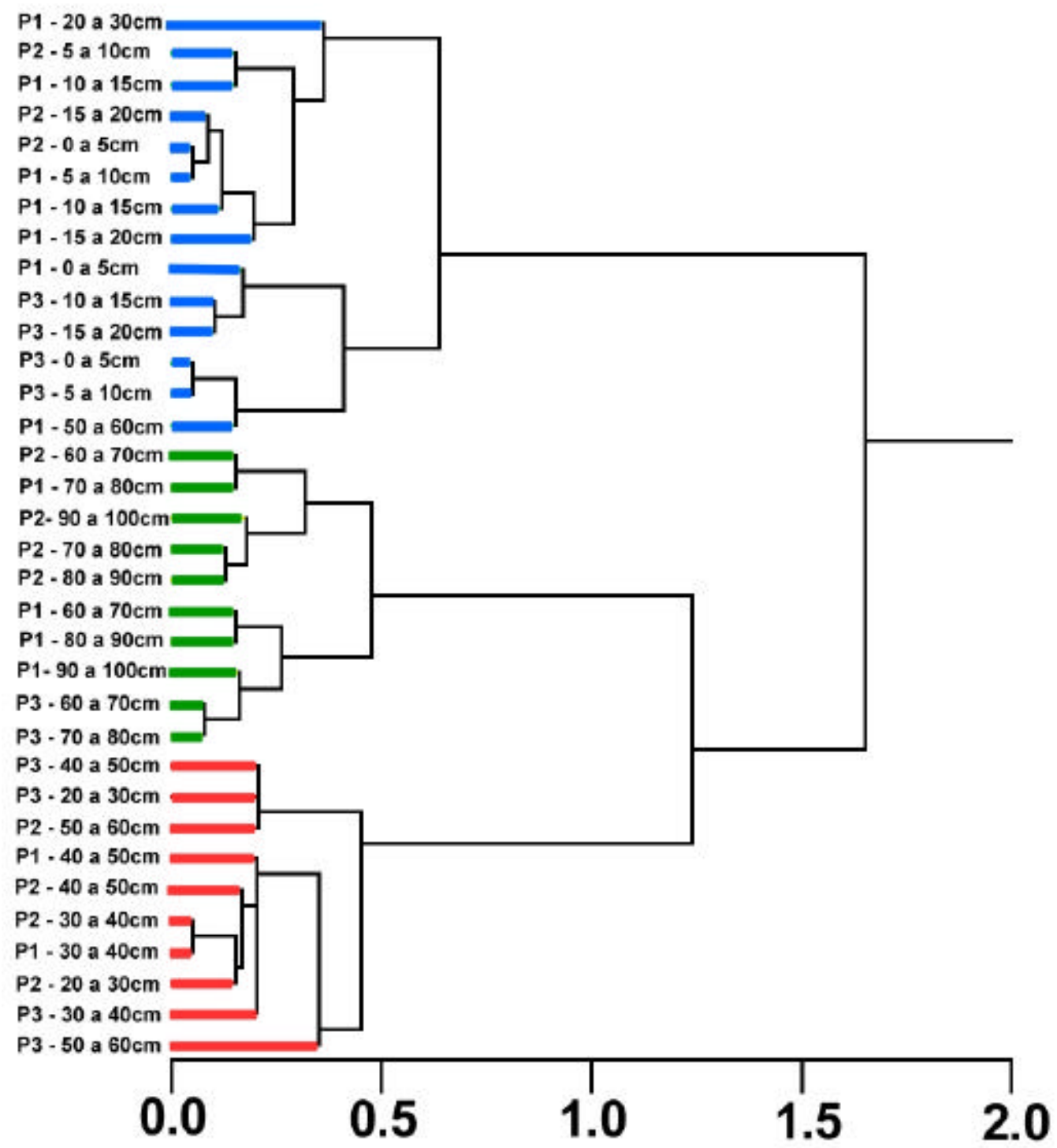

Figura 16 - Agrupamento hierárquico de amplicons de rDNA 16S de Archaea de solo de mangue contaminado com petróleo, detectadas por DGGE. 


\section{DISCUSSÃO}

\subsection{Número Mais Provável (NMP) de Bactérias Heterotróficas Aeróbias}

Apesar das limitações da utilização da contagem do número mais provável (NMP) de bactérias heterotróficas aeróbias em meios de cultura, este método pode trazer informações adicionais quando utilizado para fins de comparação (Baudoin et al., 2001). No presente estudo, a quantidade de bactérias heterotróficas aeróbias foi aproximadamente 3,5 vezes maior no solo do P3 (Figura 3A), onde a presença de petróleo era visível no momento da amostragem, do que nos pontos P1 e P2. No P2, a presença de petróleo também foi visível, mas não no momento da amostragem, e sim durante a manipulação das amostras em laboratório. Apesar disso, o número de bactérias heterotróficas aeróbias no P2 não diferiu significativamente do $\mathrm{P} 1$, o qual não apresentou petróleo visível no momento da amostragem ou no laboratório. Em

contraste, em um estudo de biodegradação de hidrocarbonetos do petróleo em manguezais, Ramsay et al. (2000) encontraram um aumento de 100 vezes no NMP de bactérias heterotróficas aeróbias do solo após a adição de petróleo. Como a contaminação da área em estudo ocorreu a 20 anos, é provável que logo após o derrame essas diferenças tenham sido mais significativas.

\subsection{Biomassa Microbiana (C-Biomassa)}

A quantificação da biomassa microbiana (C-Biomassa) é um dos parâmetros mais utilizados em estudos de impactos ambientais sobre a 
microbiota dos solos. A biomassa microbiana é um dos componentes que controlam funções chaves no solo, como a decomposição e o acúmulo de matéria orgânica, ou transformações envolvendo os nutrientes minerais. Representa, ainda, uma reserva considerável de nutrientes, os quais são continuamente assimilados durante os ciclos de crescimento dos diferentes organismos que compõem o ecossistema. Assim, solos que mantêm um alto conteúdo de biomassa microbiana são capazes não somente de estocar, mas também de ciclar mais nutrientes no sistema (Stenberg, 1999).

Já que a dinâmica do carbono no solo é mediada pelas comunidades microbianas, obviamente existe uma relação entre a quantidade e qualidade da matéria orgânica e a atividade e diversidade de microrganismos. Tem sido demonstrado que existe uma relação positiva entre a quantidade de matéria orgânica presente em um solo e a sua atividade microbiana medida pelo C-biomassa (Schnurer et al., 1985; Carter, 1986; Powlson et al., 1987; Sparling, 1992).

Apesar do maior número de microrganismos encontrados no $\mathrm{P} 3 \mathrm{e}$ das diferenças visíveis de contaminação com petróleo, não houve diferença estatística entre o C-Biomassa dos pontos estudados. No entanto, variações da quantidade de C-Biomassa entre as profundidades estudadas foram observadas (Figura 3B). Os menores valores de C-Biomassa foram encontrados na camada de 20 a $50 \mathrm{~cm}$ (Figura 3B). No entanto, com os dados disponíveis, não foi possível estabelecer uma relação direta entre a presença dos hidrocarbonetos do petróleo nesta camada com o C-biomassa observado. Os valores mais elevados de C-biomassa entre 20 e $50 \mathrm{~cm}$ de profundidade também não parecem ter correlação com os teores de M.O. do solo, já que estes, na camada de 20 a $30 \mathrm{~cm}$, não diferem muito daqueles encontrados na camada de 0 a $10 \mathrm{~cm}$ (Tabela 1). A possível inibição da atividade microbiana pela crescente anoxia não explica a variação do C-Biomassa deste solo, já que o valor de C-Biomassa na camada de 50 a $100 \mathrm{~cm}$ é estatisticamente igual ao valor observado na camada mais superficial do solo. 


\subsection{Respiração Basal (RB)}

A avaliação da respiração aeróbia em solos de mangue pode apresentar limitações, já que nas camadas mais profundas, as comunidades microbianas estão adaptadas à auxência de $\mathrm{O}_{2}$, podendo a respiração determinada pela liberação de $\mathrm{CO}_{2}$ não representar a atividade real da microbiota. Além disso, em experimentos de campo, a taxa de respiração pode ser influenciada por variações naturais que influenciam a atividade microbiana como $\mathrm{pH}$, quantidade de matéria orgânica no solo, temperatura, concentração de nutrientes, vegetação, etc (Baath et al., 1998).

A RB reflete a atividade atual da microbiota do solo, responsável pela degradação de compostos orgânicos. Os valores de RB entre os pontos estudados se relacionam diretamente com o NMP de bactérias heterotróficas aeróbias, com P1 e P2 não diferindo entre si, e estes sendo menores do que $\mathrm{P} 3$, refletindo maior atividade microbiana no $\mathrm{P} 3$, o ponto mais contaminado (Figura 4A).

A RB foi influenciada também pela profundidade de amostragem. Houve uma tendência de aumento dos valores de RB com o aumento da profundidade (Figura 4B). Esse comportamento pode estar relacionado com a presença de microrganismos anaeróbios facultativos nas camadas anóxicas.

\subsection{Respiração Induzida pelo Substrato (RIS)}

A RIS reflete o potencial de microrganismos zimógenos, os quais apresentam aumentos de atividade degradatória em resposta à adição de matéria orgânica ao solo (Anderson \& Domsch, 1978). Esta medida é geralmente utilizada para avaliar a respiração em solos estressados e/ou perturbados, já que solos estressados tendem a responder mais lentamente à adição de fontes de carbono, em relação a solos não-perturbados (Wardle, 
1994). Os resultados da tabela 4 mostram que a resposta dos microrganismos à adição de glicose em P2 foi sempre menor ou igual àresposta nos outros dois pontos, variando em função da profundidade. Essa resposta foi similar entre P1 e P3, havendo diferença apenas na camada de 0 a $5 \mathrm{~cm}$, onde a resposta em P3 foi maior do que em P1 e P2 (Tabela 4). Enquanto a RIS média de todas as amostras analisadas foi de $38,41 \mu \mathrm{g} \mathrm{C} \mathrm{g}^{-1}$ solo $\mathrm{h}^{-1}$, a RIS da amostra de 0 a $5 \mathrm{~cm}$ do $\mathrm{P} 3$ foi de $82,33 \mu \mathrm{g} \mathrm{C} \mathrm{g}^{-1}$ solo h$^{-1}$, ou seja, 53\% maior. Este maior potencial de resposta à adição de glicose pode estar relacionado à seleção de microrganismos zimógenos em função da maior quantidade de hidrocarbonetos do petróleo ainda presentes em P3. Estas bactérias, dependentes de $\mathrm{O}_{2}$ para a degradação dos hidrocarbonetos, estariam concentradas na camada superficial onde há difusão de $\mathrm{O}_{2}$. Alguns autores consideram que essa camada no solo de mangue não ultrapassa $1 \mathrm{~cm}$ de profundidade (Ramsay, 2000).

\subsection{Quociente Metabólico $\left(q \mathrm{CO}_{2}\right)$}

Uma alta taxa de respiração pode indicar tanto um distúrbio ecológico (incorporação de resíduos orgânicos, por exemplo), como um alto nível de produtividade do ecossistema (Islam \& Weil, 2000). Uma variável de interpretação mais fácil é a taxa de respiração por unidade de biomassa microbiana, ou quociente metabólico $\left(q \mathrm{CO}_{2}\right)$, o qual tem sido utilizado como um indicador de estresse microbiano e interpretado como "eficiência microbiana", já que se trata de uma medida da energia necessária para a manutenção da atividade metabólica em relação àenergia necessária para síntese de biomassa (Bardgett \& Saggar, 1994). No entanto, Khan \& Scullion (2000), avaliando alterações microbianas em decorrência de contaminações por metais, sugerem que a utilização desse índice como indicativo de estresses ou distúrbios é limitada, atribuindo alguns resultados discrepantes a alterações na estrutura da comunidade microbiana. 
$\mathrm{O}$ presente estudo mostra que não há relação entre $0 \quad q_{\mathrm{CO}} \mathrm{e}$ a presença de petróleo em solo de mangue, já que o $q \mathrm{CO}_{2}$ no $\mathrm{P} 1$, onde não foi detectado petróleo, não diferiu estatisticamente do valor observado no P3, onde existe presença visível do petróleo (Figura 5). Os resultados do $q \mathrm{CO}_{2}$ mostram que no P2 há uma maior eficiência microbiana, já que a população de microrganismos neste ponto utilizou menor quantidade de energia, medida pela respiração, para manter sua biomassa, medida pela quantidade de carbono metabolizada.

\subsection{Diversidade Metabólica}

As análises de diversidade metabólica são feitas com base na comparação dos perfis de resposta catabólica a partir do estudo do padrão de utilização de diferentes substratos de C (Garland \& Mills, 1991; Zak et al., 1994; Garland, 1996; Degens \& Harris, 1997). Uma das formas pioneiras desse tipo de estudo envolveu a incubação de suspensões de solo em microplacas Biolog ${ }^{\mathrm{TM}}$ contendo sais de tetrazólio e 95 substratos de $\mathrm{C}$ diferentes (Zak et al., 1994). Mais recentemente, foi desenvolvida a Ecoplate, que utiliza o mesmo princípio, porém com 31 substratos de $\mathrm{C}$ diferentes, com 3 repetições. Após a suspensão microbiana ser inoculada nas cavidades contendo os substratos, as placas são incubadas e a utilização de cada substrato é determinada pela absorbância a $590 \mathrm{~nm}$.

Com base na utilização desta técnica, diferenças significativas na diversidade metabólica de comunidades advindas de amostras de solo distintas foram detectadas (Zak et al.,1994; Goodfriend, 1998; Dauber \& Wolters, 2000). Neste contexto, diversidade metabólica é definida pelo número, tipo e taxa de utilização de um conjunto de substratos pela comunidade microbiana, sendo uma conseqüência da diversidade genética, dos efeitos ambientais na expressão gênica, e das interações ecológicas entre as diferentes populações (Zak et al., 1994). Wunsche et al. (1995) consideram as comunidades 
microbianas como unidades funcionais, caracterizadas pela soma das propriedades metabólicas das espécies envolvidas. Consequentemente, o padrão de utilização de substratos de toda a comunidade é resultado da diversidade de espécies e da abundância relativa de cada espécie. Assim sendo, o estudo da diversidade metabólica da microbiota do solo pode servir como um indicador de mudanças de sua qualidade ou alterações em resposta a estresses.

A diversidade metabólica pode ser examinada de diferentes modos, analogamente aos conceitos empregados em diversidade taxonômica. Uma das formas mais simples é expressar a diversidade em termos de riqueza de substratos, ou seja, do número de diferentes substratos de $C$ que podem ser utilizados pela comunidade microbiana $\left(\mathrm{S}_{\mathrm{S}}\right)$. Outro índice utilizado é o de diversidade de Shannon $(\mathrm{H})$, que compreende tanto a riqueza de substratos quanto a intensidade com que esses substratos são utilizados pela microbiota (Zak et al.,1994; Goodfriend, 1998; Dauber \& Wolters, 2000; Lupwayi et al., 2001). Já a eqüitabilidade de substratos (E) mede a uniformidade de utilização de um substrato em relação ao número de substratos utilizados pela microbiota. Garland \& Mills (1991) adaptaram o sistema Biolog para estudos de caracterização e classificação de comunidades microbianas de amostras ambientais. Já, Lupwayi et al. (2001) avaliaram a diversidade metabólica das populações bacterianas de solos submetidos a diferentes manejos. Os autores empregaram uma placa Biolog com 95 substratos e demonstraram, através de análises de agrupamento e de componentes principais, que ocorriam mudanças na estrutura da comunidade microbiana dos solos sob diferentes sistemas de manejo. Bending et al. (2000) consideram que o perfil de utilização de substratos pelos microrganismos do solo é um parâmetro mais sensível do que a medição da biomassa microbiana, quando o objetivo é avaliar a qualidade do solo através de suas propriedades microbiológicas.

Assim sendo, o estudo da diversidade funcional da microbiota do solo utilizando-se o sistema Biolog pode servir como um indicador de mudanças 
de sua qualidade ou alterações em resposta a estresses, considerando suas limitações, já que, por ser uma metodologia dependente do crescimento das células bacterianas, apenas as bactérias heterotróficas aeróbias e anaeróbias facultativas de rápido crescimento e que não são inibidas pela presença do sal tetrazólio irão utilizar os substratos do sistema (Wunsche, 1995; O'Connell et al., 2000).

Segundo Wunsche et al. (1995), o Biolog pode ser útil para a detecção de alterações na comunidade microbiana resultantes de variações ambientais, e para o monitoramento de poluição e processos de bioremediação, principalmente em situações complexas, onde a análise química se torna ineficiente.

Em um estudo utilizando um ambiente contaminado com hidrocarbonetos, Wunsche et al. (1995) mostraram que o padrão de utilização de substratos pode ser utilizado como um indicador da estrutura e atividade funcional de comunidades microbianas.

Os resultados da figura 6C mostram que houve uma diminuição gradativa da diversidade metabólica $(H)$ em função do aumento da profundidade. No entanto, esta diminuição da diversidade funcional pode não representar as atividades principais do solo, já que as atividades anaeróbias não foram avaliadas.

\subsection{Diversidade Genética}

A técnica de DGGE vem sendo muito utilizada para a análise de comunidades de bactérias em ambientes naturais, inclusive no monitoramento de mudanças das estruturas destas comunidades em função de fatores como poluição (Donner et al., 1996; Eichner et al., 1999; El Fantroussi et al., 1999; Ferris \& Ward, 1997; Ferris et al., 1997; Muyzer \& Smalla, 1998). Mas é 
importante considerar algumas limitações quando a utilizamos para um estudo de ecologia de microrganismos.

Normalmente, considera-se cada banda no gel, após o DGGE, como representando uma espécie microbiana. Porém sabe-se que muitas bactérias possuem mais de uma cópia do rDNA 16S, os quais podem apresentar diferentes mobilidades no gel com gradiente desnaturante, resultando em múltiplas bandas da mesma espécie microbiana (Nubel et al., 1996; Boon, 2000). Além disso, apesar de teoricamente ser capaz de distinguir fragmentos de DNA que diferem em apenas um par de bases, Jackson et al. (2000) mostraram, em seu estudo com E. coli, que esta técnica não foi capaz de identificar diferenças entre mutantes que continham dois pares de bases distintos no fragmento de rDNA 16S. Isso significa que uma banda detectada no gel pode representar mais de uma espécie bacteriana, com diferentes seqüências, mas mesmo conteúdo de $\mathrm{G}+\mathrm{C}$.

Outra limitação da técnica é a amplificação preferencial de algumas sub-populações dentro de uma comunidade microbiana complexa, durante o PCR, de modo que as bandas observadas representam apenas as espécies mais abundantes na amostra (Vetriani et al., 1999). Adicionalmente, os iniciadores utilizados também podem interferir nos resultados. Chang et al. (2000), analisando a comunidade microbiana de ambientes aquáticos contaminados com petróleo através de DGGE, encontrou resultados diferentes em função do conjunto de iniciadores utilizados.

Devido a essas limitações, pode-se afirmar que o número de espécies presentes em um ambiente como o solo é muito maior do que aquele estimado por análise de amplicons do rDNA 16S por DGGE.

O DGGE pode ser mais adequado quando o objetivo é comparar duas ou mais amostras (Muyzer et al, 1993 e Jackson, 2000). Se as amostras apresentarem padrões de bandeamento diferentes, então, certamente as comunidades microbianas apresentam diferenças. Caso o padrão de bandeamento seja o mesmo, então estas diferenças podem estar ou não 
presentes, havendo a necessidade do emprego de outras técnicas para detectá-las.

Ocorreu variação de $S_{E}$ de Bacteria no $\mathrm{P} 2$ e P3, em função da profundidade de amostragem (Figura 10). No P2, foram observadas de 15\% (20 a $30 \mathrm{~cm}$ ) a $85 \%(0$ a $5 \%$ ) das 41 espécies detectadas. Já no P3, foram observadas de $17 \%$ (40 a $50 \mathrm{~cm})$ a $68 \%(15$ a $20 \mathrm{~cm})$ de todas as espécies detectadas. Estas variações possivelmente estão relacionadas com a presença do petróleo em diferentes profundidades no P2 e P3, considerando que no P1, onde o petróleo não foi detectado, ocorre de $44 \%$ (60 a $70 \mathrm{~cm}$ e 80 a $90 \mathrm{~cm}$ ) a $73 \%$ (10 a $15 \mathrm{~cm})$ de todas as espécies observadas.

É importante notar que a riqueza de espécies de Bacteria em P1 é menor nas maiores profundidades. Isso pode estar relacionado à baixa capacidade de adaptação das bactérias do domínio Bacteria, a ambientes anóxicos, ao contrário das bactérias do domínio Archaea. Ovreas et al. (1997), estudando a diversidade microbiana em um lago com gradiente de salinidade e oxigenação, uitlizando os mesmos conjuntos de iniciadores utilizados no presente trabalho, encontrou maior diversidade de Bacteria em amostras mais superficiais e maior diversidade de Archaea nas amostras mais profundas.

lbekwe et al. (2001), utilizando os mesmos iniciadores para o domínio Bacteria utilizados neste estudo, detectou 16 espécies de bactérias no tratamento controle de um solo agrícola, sem a aplicação de fumigantes. No presente estudo, o número de espécies de Bacteria detectadas nas amostras variou de 6 a 35 (Figura 10) e o de Archaea de 11 a 30 (Figura 11), indicando que os manguezais possuem uma grande riqueza de espécies $\left(S_{E}\right)$ de bactérias. Segundo Zhou et al. (2002), existem alguns fatores que contribuem para a grande diversidade microbiana do solo de mangue. Estes solos estão sujeitos a frequentes flutuações das condições ambientais, permitindo a manutenção de uma maior riqueza de espécies, já que não há seleção das espécies por adaptação a condições ambientais mais permanentes. $O$ solo de mangue está permanentemente saturado com água, a qual se movimenta com 
os fluxos e refluxos da maré. Em superfície isto diminui a possibilidade de formação de micro-sítios contendo comunidades microbianas distintas, contribuindo para uma maior homogeneidade na distribuição horizontal das espécies microbianas em uma área. As fontes de carbono e nutrientes presentes no solo de mangue são diversificadas, já que têm origem terrestre, marinha e do próprio sistema, permitindo o estabelecimento de uma maior diversidade de espécies.

O domínio Archaea engloba microrganismos que se desenvolvem em ambientes específicos, incluindo aqueles com altas temperatura e salinidade, extremos de $\mathrm{pH}$ e auxência de oxigênio, sendo dividido em dois grupos principais: Euryarchaeota e Crenarchaeota. O primeiro grupo é considerado o grupo mais diversificado fisiologicamente $e$ inclui os microrganismos metanogênicos, que crescem em nichos estritamente anaeróbios, além dos halófilos e termófilos. O segundo grupo é mais restrito, englobando os microrganismos termófilos extremos que metabolizam o enxofre liberado por fontes hidrotermais (Vetriani et al., 1999). Alguns estudos levam a crer que os microrganismos do domínio Archaea são dominantes em ambientes marinhos e, talvez, o grupo mais abundante no planeta (DeLong, 1992; DeLong et al., 1994; Fuhrman et al, 1993). Outros revelam que em ambientes marinhos - grupo Euryarchaeota é mais abundante na superfície e o Crenarchaeota em profundidade (Massana et al., 1997 e 1998).

A riqueza de espécies do domínio Archaea foi menos influenciada pelo Ponto e/ou Profundidade de amostragem do que as espécies do domínio Bacteria. Isto pode estar relacionado com a maior facilidade de adaptação das arquebactérias a ambientes extremos, sendo menos sensíveis à contaminação com petróleo. Além disso, o tempo decorrido desde o derramamento (20 anos) pode ter sido suficiente para a estruturação de uma comunidade de Archaea que não sofre mais os efeitos da presença de petróleo. Em contraste, Sandaa et al. (1999) encontraram uma diminuição da diversidade de Archaea em solo agrícola em função da contaminação com metais pesados, utilizando DGGE e o 
mesmo conjunto de iniciadores utilizado no presente trabalho, sugerindo que esses microrganismos podem ser utilizados como indicadores de poluição por metais.

Os padrões de bandeamento encontrados com o emprego de DGGE em estudos com solo e sedimento, que contêm comunidades microbianas com alta diversidade, são muito complexos. O número e ocorrência das bandas podem ser utilizadas para a comparação entre comunidades contidas em diferentes amostras, através de agrupamento hierárquico (Boon et al., 2000). As análises realizadas no presente estudo mostram que o padrão de bandeamento dos amplicons do rDNA $16 \mathrm{~S}$ de microrganismos do domínio Bacteria se agrupam preferencialmente em função do fator PONTO, indicando um condicionamento da estrutura da comunidade microbiana em função da presença do petróleo (Figura 15). O mesmo não ocorre com Archaea, que mostra um agrupamento preferencial em função do fator PROFUNDIDADE, indicando um condicionamento da estrutura da comunidade microbiana em função de fatores ambientais, como anoxia, por exemplo (Figura 16). Assim, as bactérias do domínio Bacteria seriam as mais indicadas como bioindicadores da recuperação de mangues contaminados com petróleo, pelo menos para longos períodos após o derramamento.

Nesse estudo não foi possível avaliar o impacto do petróleo sobre as comunidades logo após o derramamento, quando o impacto sobre as bactérias do domínio Archaea poderia ter sido maior. Estudos sobre este grupo de microrganismos, os quais certamente desempenham papel importante nos processos que ocorrem no solo de mangue, devem ser conduzidos, visando uma melhor caracterização das respostas dessa comunidade a impactos ambientais.

A eliminação de espécies de microrganismos sensíveis a um distúrbio qualquer favorece o aumento da população de outros microrganismos presentes neste solo e que são mais tolerantes ao distúrbio, resultando em uma alteração na composição de espécies (Díaz-Raviña \& Baath, 1996). Segundo 
Ramsay et al. (2000), as populações microbianas em solo de mangue possuem potenciais degradadores de hidrocarbonetos, e isto deve estar relacionado à adaptação destes microrganismos à grande quantidade de matéria orgânica presente nestes solos. Em um estudo com solo exposto durante vários anos à contaminação com hidrocarbonetos, Wunsche et al. (1995) encontraram uma dominância do gênero Pseudomonas entre os microrganismos, especialmente $P$. boxyhydrogena. No mesmo estudo, em um ensaio com a adição de hidrocarbonetos no solo, $P$. putida foi a espécie dominante. Se considerarmos que as variações de $S_{E}$ de Bacteria estão relacionadas com a presença de petróleo, então podemos dizer que possivelmente as amostras que contêm menor $S_{E}$ são dominadas por espécies selecionadas pela poluição, mais aptas a utilizar os hidrocarbonetos do petróleo.

As alterações na estrutura das comunidades bacterianas detectadas não refletem as alterações na diversidade funcional da comunidade, já que a análise utilizando Biolog não detectou diferenças de diversidade metabólica entre os pontos estudados, indicando alto grau de redundância de funções fisiológicas, provavelmente porque o Biolog avaliou somente as capacidades metabólicas de microrganismos aeróbios e anaeróbios facultativos. Para a avaliação da capacidade metabólica total da comunidade de bactérias dos solos de mangue seria necessário avaliar também a capacidade metabólica das bactérias aeróbias estritas. 


\section{CONCLUSÕES}

Os resultados obtidos mostraram que, após 20 anos, o petróleo remanescente no mangue impactado ainda causa efeitos sobre a atividade e a diversidade genética da população de bactérias do solo.

Não foram detectadas diferenças de diversidade funcional em função dos diferentes níveis de contaminação existentes na área.

O solo de mangue apresenta uma grande diversidade genética de bactérias dos domínios Bacteria e Archaea, sendo importante a condução de estudos que contribuam para o melhor ente ndimento desta diversidade.

As técnicas moleculares baseadas na variabilidade do rDNA 16S se mostraram mais eficientes do que as técnicas dependentes de atividade metabólica na detecção de alterações na estrutura da comunidade bacteriana em função da contaminação com petróleo.

A alteração na diversidade de bactérias do domínio Bacteria é um parâmetro que pode vir a ser utilizado como indicador biológico em casos de contaminação como o do presente estudo, já que é mais sensível ao petróleo remanescente do que as bactérias do domínio Archaea. 


\section{REFERÊNCIAS BIBLIOGRÁFICAS}

AQUINO, M.C. A importância biológica do mangue. Apicultura no Brasil, v. 4, p.8, 1987.

ALEXANDER, M. Introduction to soil microbiology. 4.ed. New York: John Wiley, 1977. 472p.

AMANN, R.I.; LUDWIG, W. Ribosomal RNA-targeted nucleic acid probes for studies in microbial ecology. Microbiology Reviews, v.24, p.555-565, 2000.

AMANN, R.I.; LUDWIG, W.; SCHLEIFER, K.H. Phylogenetic indentification and in situ detection of individual microbial cells without cultivation. Microbiology Reviews, v.59, p.143-169, 1995.

ANDERSON, J.P.E.; DOMSCH, K.E. A physiological method for the quantitative measurement of microbial biomass in soils. Soil Biology and Biochemistry, v.10, p.215-221, 1978.

ANDRADE, D.S.; HAMAKAWA, P.J. Estimativa do número de rizóbio no solo e inoculantes por infecção em planta. In: HUNGRIA, M.; ARAUJO, R.S. Manual de métodos empregados em estudos de microbiologia agrícola. Brasília: EMBRAPA, 1994. cap.3, p.63-94. 
ATLAS, R.M. Microbial degradation of petroleum hydrocarbons: an environmental perspective. Microbiology Reviews, v.45, p.180-209, 1981.

ATLAS, R.M. Use of microbial diversity measurements to assess environmental stress. In: KLUG M.J.; REDDY C. A. Current perspectives in microbial ecology. Washington: American Society for Microbiology, 1984. p.540-545.

ATLAS, R.M. Petroleum biodegradation and oil spill bioremediation. Marine Pollution Bulletim, v.31, p.178-182, 1995.

ATLAS, R.M.; BARTHA, R. Hydrocarbon biodegradation and oil spill bioremediation. Advances in Microbial Ecology, v.12, p.287-338, 1992.

BAATH, E. Growth rates of bacterial communities in soils at varying $\mathrm{pH}$ : a comparison of the thymidine and leucine incorporation techniques. Microbial Ecology, v.36, p.316-327, 1998.

BAKER, J.M.; GUZMAN, L.; BARTLETT, P.D.; LITTLE, D.I.; WILSON, C.M. Long-term fate and effects of untreated thick oil deposits on salt marshes. In: THE 1993 INTERNATIONAL OIL SPILL CONFERENCE, Washington, 1993. Proceedings. Washington: American Petroleum Institute Publication, 1993. p.395-399.

BANDYOPADHYAY, B.K.; MAJI, B. Nature of acid soils of Sunderbans delta and suitability of classifying them as acid sulphate or potential acid sulphate soils. Journal Indian Society of Soil Science, v.43, p.251-255, 1995.

BARDGETT, R.D.; SAGGAR, S. Effect of heavy metal contamination on the short-term decomposition of labeled $\left({ }^{14} \mathrm{C}\right)$ in a pasture soil. Soil Biology and Biochemistry, v.26, p.727-733, 1994. 
BAUDOIN, E.; BENIZRI, E.; GUCKERT, A. Metabolic fingerprint of microbial communities from distinct maize rhizosphere compartments. European Journal of Soil Biology, v.37, p.85-93, 2001.

BENDING, G.D.; PUTLAND, C.; RAYNS, F. Changes in microbial community metabolism and labile organic matter fractions as early indicators of the impact of management on soil biological quality. Biology and Fertility of Soils, v.31, p.78-84, 2000.

BENLLOCH, S.; MARTINEZ-MURCIA, A.J.; RODRIGUEZ-VALERA, F. Sequencing of bacterial and archaeal 16S rRNA genes directly amplified from a hypersaline environment. Systematic and Applied Microbiology, v.18, p. 574-581, 1995.

BIENERT, R.W.; PEARSON, W.H. Application of ecological risk assessment principles to questions of oil exposure in Pacific herring following the Exxon Valdez spill. Canadian Technical Report of Fisheries and Aquatic Sciences, n.2060, p.219-225, 1995.

BOON, N.; MARLÉ, C.; TOP, E.M.; VERSTRAETE, W. Comparison ofthe spatial homogeneity of physico-chemical parameters and bacterial 16S rRNA genes in sediment samples from a dumping site for dredging sludge. Applied Microbiology and biotechnology, v.53, p.742-747, 2000.

BRADDOCK, J.F.; LINDSTROM, J.E.; YEAGER, T.R.; RASLEY, B.T.; BROWN, E.J. Patterns of microbial activity in oiled and unoiled sediments in Prince William Sound. In: EXXON VALDEZ. Proceedings of the Exxon Valdez oil spill symposium. Bethesda: American Fisheries Society, 1996. v.18, p.94108. 
BRERETON, A.J. The structure of the species population in the initial stages of salt marsh succession. Journal Ecology, v.59, p.321-338, 1971.

BRESLAUER, K.J.; FRANK,R.; BLOCKER, H.; MARKY, L.A. Predicting DNA duplex stability from the base sequence. Proceedings of the National Academy of Sciences of the U.S.A., v. 83, p.3746-3750, 1986.

BROOKES, P.C. The use microbial parameters in monitoring soil pollution by heavy metal. Biology and Fertility of Soils, v.19, p.269-279, 1995.

BUE, B.G.; SHARR, S.; SEEB, J.E. Evidence of damage to pink salmon populations inhabiting Prince William Sound, Alaska, two generations after the Exxon Valdez oil spill. Transactions of the American Fisheries Society, v.127, p.35-43, 1998.

CAMARGO, O.A.; MONIZ, A.C.; JORGE, J.A.; VALADARES, J.M.A.S. Métodos de análise química, mineralógica e física de solos do Instituto Agronômico de Campinas. Campinas: Instituto Agronômico, 1986. 94p. (Boletim Técnico, 106).

CARDONA, P.; BOTERO, L. Soil characteristics and vegetation structure in a heavily deteriorated mangrove forest in the Caribbean Coast of Colombia. Biotropica, v.30, p.24-34, 1998.

CARTER, M.R. Microbial biomass as a index for tillage-induced changes in soil biological properties. Soil Tillage Research, v.7, p.29-40, 1986. 
CHANG, Y.J.; STEPHEN, J.R.; RICHTER, A.P.; VENOSA, A.D.; BRUGGEMANN, J.; MACNAUGHTON, S.J.; KOWALCHUK, G.A.; HAINES, J.R.; KLINE, E.; WHITE, D.C. Phylogenetic analysis of aerobic freshwater and marine enrichmento cultures efficient in hydrocarbon degradation: effect of profiling method. Journal of Microbiological Methods, v.40, p.19-31, 2000.

CLARK, R.C.; FINLEY, J.S. Occurence and impact of petroleum on Arctic environments. In: REY, L. (Ed.). The arctic ocean - the hydrographic environment and the fate of pollutants. New York: John Wiley, 1982. p.295 -314.

CLARKE, P.J.; WARD, T.J. The response of southern hemisphere saltmarsh plants and gastropods to experimental contamination by petroleum hydrocarbons. Journal of Experimental Marine Biology and Ecology, v.175, p.43-57, 1994.

DAUBER, J.; WOLTERS. V. Microbial activity and functional diversity in the mounds of three different ant especies. Soil Biology and Biochemistry, v.32, p. 93-99, 2000.

DEGENS, B.P.; HARRIS, J.A. Development of a physiological approach to measuring the catabolic diversity of soil microbial communities. Soil Biology and Biochemistry, v.29, p.1309-1320, 1997.

DELAUNE, R.D.; PATRICK, W.H.; BURESH, R.J. Sedimentation rates determined by $137 \mathrm{Cs}$ dating in a rapidly acceting salt marsh. Nature, v.275, p.532-533, 1978. 
DeLONG, R.F. Archaea in costal marine environments. Proceedings of the National Academy of Sciences of the U.S.A., v.89, p.5685-5689, 1992.

DeLONG, R.F.; WU, K.Y.; PREZELIN, B.B.; JOVINE, R.V.M. High abundance of Archaea in Antarctic marine picoplankton. Nature, v.371, 695-697, 1994.

DEMAS, G.P.; RABENHORST, M.C. Subaqueous soils: pedogenesis in a submersed environment. Soil Science Society of America Journal, v.63, p.1250-1257, 1999.

DÍAZ-RAVIÑA, M.; BAATH, E. Development of metal tolerance in soil bacterial communities exposed to experimentally increased metal levels. Applied and Environmental Microbiology, v.62, p.2970-2977, 1996.

DONNER, G.; SCHWARZ, K.; HOPPE, H.G.; MUYZER, G. Profiling the succession of bacterial populations in pelagic chemoclines. Archives of Hydrobiology, v.48, p.7-14, 1996.

DORAN J.W. Soil quality and sustainability. In: CONGRESSO BRASILEIRO DE CIÊNCIA DO SOLO, 26., Rio de Janeiro, 1997. Rio de Janeiro: Comissão do "V Inventory, Genesis, Morphology and Clasification of Soils", 1997. 19p.

EICHNER, C.A.; ERB, R.W.; TIMMIS, K.N.; WAGNER-DOBLER, I. Thermal gradient gel electrophoresis analysis of bioprotection fom pollutant shocks in the activated sludge microbial community. Applied and Environmental Microbiology, v.65, p.102-109, 1999. 
EL FANTROUSSI, S.; VERSCHUERE, L; VERSTRAETE, W.; TOP, E.M. Effect of phenylurea herbicides on soil microbial communities estimated by analysis of $16 \mathrm{~S}$ rRNA gene fingerprints and community-level physiological profiles. Applied and Environmental Microbiology, v.65, p.982-988, 1999.

EMPRESA BRASILEIRA DE PESQUISA AGROPECUÁRIA. Centro Nacional de Pesquisa de Solos. Manual de métodos de análise de solo. 2.ed. Rio de Janeiro, 1997. 212p.

EMPRESA BRASILEIRA DE PESQUISA AGROPECUÁRIA. Centro Nacional de Pesquisa de Solos. Sistema brasileiro de classificação de solos. Rio de Janeiro, 1999. 412p.

FERRIS, M.J.; NOLD, S.C.; REVSBECH, N.B.; WARD. D.M. Population structure and physiological changes within a hot spring microbial mat community following disturbance. Applied and Environmental Microbiology, v.63, p.1367-1374, 1997.

FERRIS, M.J.; WARD, D.M. Seasonal distributions of dominant 16S rRNAdefined populations in a hot spring microbial mat examined by denaturing gradient gel electrophoresis. Applied and Environmental Microbiology, v.63, p.1375-1381, 1997.

FIDELMAN, P.I.J. Impactos causados por tensores de origem antrópica no sistema estuarino do Rio Santana, Ilhéus, Bahia. In: SEMANA NACIONAL DE OCEANOGRAFIA. 12., Rio de Janeiro, 1999. Resumos expandidos. Rio de Janeiro: UERJ, 1999. p.405-407. 
FITZPATRICK, R.W.; HUDNALL, W.H.; SELF, P.G.; NAIDU, R.; DENT, D.L.; MENSWOORT, M.E.F. Origin and properties of island and tidal saline and acid sulphate soils in South Australia. In: 4. INTERNATIONAL SYMPOSIUM ON ACID SULPHATE SOILS 4., Ho Chi Minh, 1992. Selected papers. Wageningen: Ed. ILRI, 1993. p.71-80

FLOODGATE, G.D. Some environmental aspects of marine hydrocarbon bacteriology. Aquatic Microbial Ecology, v.9, p.3-11, 1995.

FUHRMAN, J.A.; McCALLUM; DAVIS, A. Phylogenetic diversity of subsurface marine microbial communities from the Atlantic and Pacific Oceans. Applied and Environmental Microbiology, v.59, p.1294-1302, 1993.

GAMERO, R. M. P. Mineralogia, físico-química e classificação dos solos de mangue do Rio Iriri no Canal de Bertioga (Santos, SP). Piracicaba, 2001. 76p. Dissertação (Mestrado) - Escola Superior de Agricultura "Luiz de Queiroz", Universidade de São Paulo.

GARLAND, J.L. Patterns of potential c source utilization by rhizospher communities. Soil Biology and Biochemistry, v.28, p.223-230, 1996.

GARLAND, J.L.; MILLS, A.L.; Classification and characterization of heterotrophic source utilization. Applied Environmental and Microbiology, v.57, p.2351-2359, 1991.

GESAMP (IMO/FAO/UNESCO/WMO/IAEA/UNEP) Joint group of experts on the scientific aspects of marine pollution). Impact of oil and related chemicals and wastes on the marine environment. GESAMP, 1993. v.50180p. 
GETTER, C.D.; CINTRON, G.; DICKS, B.; LEWIS, R.R.; SENECA, E.D. The recovery and restoration of salt marshes and mangrove following an oil spill. In: CAIRNS, J; BUIKEMA, A.L. (Ed.) Restoration of habitats impacted by oil spills. Boston: Butterworth, 1984, p.65-113.

GETTER, C.D.; SCOTT, G.I.; MICHEL, J. The effects of oil spills on mangrove forests: a comparison of five oil spill sites in the Gulf of Mexico and the Caribbean Sea. In: THE 1981 OIL SPILL CONFERENCE, Baltimore, 1981. Proceedings. Washington: American Petroleum Institute, 1981. p.535-540.

GOODFRIEND, W.L. Microbial community patterns of potential substrate utilization: a comparison of salt marsh, sand dune, and seawater-irrigated agronomic systems. Soil Biology and Biochemistry, v.30, p.1169-1176, 1998.

HOWARTH, R.W. Assessing the ecological effects of oil pollution from outer continental shelf oil development. Transactions of American Fisheries Society. v.11, p.1-8, 1991.

HUGENHOLTZ, P. Exploring prokaryotic diversity in the genomic era. Genome Biology. 3(2): reviews 003.1-003.8. http//genomebiology.com/2002/3/2/ reviews/0003. (13 Abr. 2002)

IBEKWE, A.M.; KENNEDY, A.C. Phospholipid fatty acid profiles and carbon utilization patterns for analysis of microbial communitu structure unde rield and greenhhouse conditions. FEMS Microbiology Ecology, v.26, p.151-163, 1998. 
IBEKWE, A.M.; PAPIERNIK, S.K.; GAN, J.; YATES, S.R.; YANG, C.H.; CROWLEY, D.E. Impact of fumigants on soil microbial communities. Applied and Environmental Microbiology, v.67, n.7, p.3245-3257, 2001.

INSAN, H. A new set of substrates proposed for community characterization in environmental samples. In: Insan, H., Rangger, A. (Ed.) Microbial Communities. Berlin: Springer, 1997. p.259-260.

ISLAM, K.R.; WEIL, R.R. Soil quality indicator properties in mid-Atlantic soils as influenced by conservation management. Journal of Soil and Water Conservation, v.55, p.69-78, 2000.

JACKSON, C.R.; RODEN, E.E.; CHURCHILL, P.F. Denaturing gradient gel electrophoresis can fail to separate 16S rDNA fragments with multiple base differences. Molecular Biology Today, v.1, p.49-51, 2000.

KHAN, M; SCULLION, J. Effect of soil on microbial responses to metal contamination. Environmental Pollution, v.110, p.115-125, 2000.

KENNEDY, A. C.; SMITH, K.L. Soil microbial diversity and the sustainability of agricultural soils. Plant and Soil, v.170, p.75-86, 1995.

LANI, J.L. Deltas dos rios Doce e Itapemirim; solos, com ênfase nos tiomórficos, água e impacto ambiental do uso. Viçosa, 1998. 169p. Tese (Doutorado) Universidade Federal de Viçosa.

LEAHY, J.G.; COLWELL, R.R. Microbial degradation of hydrocarbons in the environment. Microbiology Reviews, v.54, n.3, p.305-315, 1990. 
LUPWAYI, N.Z.; ARSHAD, M.A.; RICE, W.A.; CLAYTON, G.W. Bacterial diversity in water-stable aggregates of soils under conventional and zero tillage management. Applied Soil and Ecology, v.16, p.251-261, 2001.

LYNCH, J.M.; BRAGG, E. Microrganism and soil aggregate stability. Advances in Soil Science, v.2, p.133-171, 1985.

MASSANA, R.; MURRAY, A.E.; PRESTON, C.M.; DeLONG, E.F. Vertical distribution and phylogenetic characterization of marine planktonic Archaea in Santa Barbara Channel. Applied and Environmental Microbiology, v.63, p.50-56, 1997.

MASSANA, R.; TAYLOR, L.T.; MURRAY, A.E.; WU, K.Y.; JEFFREY, W.H.; DeLONG, E.F. Vertical distribution and temporal variation of marine planktonic Archaea in the Gerlache Strait, Antarctica, during early spring. Limnology and Oceanography, v.43, p.607-617, 1998.

MELLO, I.S.; AZEVEDO, J.L. Ecologia microbiana. Jaguariúna: Embrapa, CNPMA, 1998. 488p.

MICHEL, J. Adverse effects from oil. http://www.darcnw.noaa.gov/iad_apd.pdf (16 Abr. 2002).

MOGG, A.O.D. A preliminary investigation of the significance of salinity in the zonation of species in salt marsh and mangrove swamp associations. South African Journal Science, v.59, n.3, p.81-86, 1963.

MOSCATELLI, M. Salvando o Manguezal. Revista Brasileira de Ecologia do Século 21-Eco, n.41, p.41-42, 1999. 
MOYER, C.L.; TIEDJE, J.M.; DOBBS, F.C.; KARL, D.M. Diversity of deep-sea hydrothermal vent Archaea from Loihi Seamount, Hawaii. Deep-sea Research, v.45, p.303-317, 1998.

MUYZER, G. Genetic fingerprinting of microbial communities - present status and future perspective. In: INTERNATIONAL SYMPOSIUM ON MICROBIAL ECOLOGY, 8., Halifax, 1999. Proceedings. http://plato.acadiau.ca/ isme/Symposium16/muyzer.PDF (9 Mar. 2002).

MUYZER, G.; RAMSING, N.B. Molecular methods to study the organization of microbial communities. Water Science Technology, v.32, p.1-9, 1995.

MUYZER,G.; SMALLA, K. Application of denaturing gradient gel electrophoresis (DGGE) and temperature gradient gel electrophoresis (TGGE) in microbial ecology. Antonie van Leeuwenhoek Journal of Microbiology, v.73, p.27$141,1998$.

MUYZER, G.; WAAL, E.C. de; UITTERLINDEN, A.G. Profiling of complex microbial populations by denaturing gradient gel electrophoresis analysis of polymerase chain reaction-amplified genes encoding for 16S rRNA. Applied and Environmental Microbiology, v.59, p.695-700, 1993.

NATIONAL OCEANIC AND ATMOSPHERIC ADMINISTRATION. Primary Restoration: Guidance document for natural resource damage assessment under the oil pollution act of 1990. 762p. http://www.darcnw.noaa.gov/ (7 Mar. 2002). 
NELSON-SMITH, A. Biological consequences of oil-spills in Arctic waters. In: REY L. (Ed.). The arctic ocean: the hydrographic environment and the fate of pollutants. New York: John Wiley, 1982, p.275-293.

NUBEL, U.; ENGELEN, B.; FELSKE, A.; SNAIDR, J.; WIESHUBER, A.; AMANN, R.I.; LUDWIG, W.; BACKHAUS, H. Sequence heterogeneties of genes encoding 16S rRNAs in Paenibacillus polymixa detected by temperature gradient gel electrophoresis. Journal of Bacteriology, v.178, p.5636-5643, 1996.

O'CONNELL, S.; LAWSON, R.D.; WATWOOD, M.E.; LEHMAN, R.M. Basic program for reduction ofdata from community-level physiologycal profiling using Biolog microplates: rational and critical interpretation of data. Journal of Microbiological Methods, v.40, p.213-220, 2000.

ODUM, E.P. Ecologia. 3.ed México: Nueva Editorial Interamericana, 1972. $639 p$.

ODUM, W.E.; Mc IVOR, C.C.; SMITH, T.J.. The ecology of the mangroves of the South Florida: a community profile. Washington: OBS Publication, 1982. 144p.

OVREAS, L; FORNEY, L.; DAAE, F.L. TORSVIK, V. Distribution of bacterioplankton in meromictic lake saelevannet, as determined by denaturing gradient gel electrophoresis of PCR-amplified gene fragments coding for 16S rRNA. Applied Environmental Microbiology, v.63, n.9, p.3367-3373, 1997. 
PACE, N.R.; STAHL, D.A.; LANE, D.J.; OLSEN, G.J. The analysis of natural microbial populations by ribossomal RNA sequences. Advances in Microbial Ecology, v.9, p.1-55, 1986.

PONTE, A.C.E.; FONSECA, I.A.Z.; CLARO, S.M.C.A. Impacto causado por petróleo no manguezal do Canal de Bertioga - Estrutura da Vegetação. In: SIMPÓSIO SOBRE ECOSSISTEMAS DA COSTA SUL E SUDESTE BRASILEIRA: SÍNTESE DE CONHECIMENTO, Canaceia, 1987. Anais. São Paulo: ACIESP, 1987. v.2, p.138-147.

POWLSON, D.S.; BROOKES, P.C., CHRISTENSEN, B.T. Measurement of soil microbial biomass provides an early indication of changes in total soil organic matter due to straw incorporation. Soil Biology and Biochemistry, v.19, p.159-164, 1987.

RAMSAY, M.A.; SWANNELL, R.P.J.; SHIPTON, W.A.; DUKE, N.C.; HILL, R.T. Effect of bioremediation on the microbial community in oiled mangrove sediments. Marine Pollution Bulletin, v. 41, p.413-419, 2000.

RASMUSSEN, L.D.; SORENSEN, S.J. Effects of mercury contamination on the culturable heterotrophic, functional and genetic diversity of the bacterial community in soil. Fems Microbiology Ecology, v. 36, p. 1-9, 2001.

REBER, H.H. Simultaneous estimates of the diversity and the degradative capability of heavy-metal-affected soil bacterial communities. Biology and Fertility of Soils, v.13, p.181-186, 1992.

ROSSI, M. Fatores formadores da paisagem litorânea: A Bacia do Guaratuba, São Paulo. São Paulo, 1999. 168p. Tese (Doutorado) - Faculdade de Fisiologia, Letras e Ciências Humanas, Universidade de São Paulo. 
ROSSI, M.; MATTOS, I.F. O ecossistema mangue - Uma analise dos solos e da vegetação no Estado de São Paulo. In: CONGRESSO NACIONAL SOBRE ESSÊNCIAS NATIVAS: Conservação da biodiversidade, 2., São Paulo, 1992. Anais. São Paulo: Instituto Florestal, 1992. p.930-936.

SANDAA, R.A.; ENGER, O.; TORSVIK, V. Abundance and diversity of Archaea in heavy-metal contaminated soils. Applied and Environmental Microbiology. v.65, n.8, p.3293-3297, 1999.

SCHERRER, P; MILLE, G. Biodegradation of crude oil in an experimentally polluted peaty mangrove soil. Marine Pollution Bulletin, v.20, n.9, p.430432, 1989.

SHRIADAH, M.M.A. Heavy metals in mangrove sediments of the United Arab Emirates shoreline (Arabian Gulf). Water, Air and Soil Pollution, v.116, p.523-534, 1998.

SCHNURER, J.; CLARHOLM, M.; ROSSWALL, T. Microbial biomass and activity in an agricultural soil with different organic matter contents. Soil Biology and Biochemistry. v.17, p.611-618, 1985.

SLOAN, N.A. Oil Impacts on cold-water marine resources: a review relevant to Parks Canada's evolving marine mandate. http://parkscanada.pch.gc.ca/ library/DownloadDocuments/DocumentsArchive/occasional_paper11_e.PDF (16 Abr. 2002).

SORIANO-SIERRA, E.J. Ecossistemas de marismas. O Biotipo. v.71, n.2, p.132-141, 1990. 
SORIANO-SIERRA, E.J. Etude ecologique des marais salés du Bassin d'Arcachon, structure et evolution des schorres, production et dégradation de leur vegetation et bassin. Bordeauxm, 1992. 256p. Thèse (Doctorat)Université Bordeaux.

SPARLING, G.P. Ratio of microbial biomass carbon to soil organic carbon as a sensitive indicator of changes in soil organic matter. Australian Journal of Soil Research, v.30, p.195-207, 1992.

SPIES, R.B.; RICE, S.D.; WOLFE, D.A.; WRIGHT, B.A. The effects of the Exxon Valdez oil spill on de Alaskan coastal environment. In: EXXON VALDEZ Proceedings of the Exxon Valdez oil spill symposium. Bethesda: American Fisheries Society Symposium, 1996. v.18, p.1-16.

STENBERG, B. Monitoring soil quality of arable land: microbiological indicators. Soil and Plant Science, v.49, p.1-24, 1999.

STRALHER, A.N.; STRALHER, A.H. Geografía física. 3.ed. Barcelona: Omega, 2000. 550p.

STRICKLAND, R.M. The Pacific northwest coast: fossil fuel frontier. Environment Journal, v.6, p.25-77, 1990.

SUCHANEK, T.H. Oil impacts on marine invertebrate populations and communities. American Zoologist, v.33, p.510-523, 1993.

SUGIMOTO, N.; NAKANO, S.; YONEYAMA, M.; HONDA, K. Improved thermodynamic parameters and helix initiation factor to predict stability of DNA duplexes. Nucleic Acids Research, v.24, p.4501-4505, 1996. 
TEAL, J.M.; FARRINGTON, J.W.; BURNS, K.A.; STEGMAN, J.J.; TRIPP, B.W.; WOODIN, B.; PHINNEY, C. The west falmouth oil spill after 20 years: fate of fuel oil compounds and effects on animals. Marine Pollution Bulletin, v.24, p.607-614, 1992.

THOM, B.G. Mangrove ecology: A geomorphological perspective. In: Clough, B. (Ed.). Mangrove ecosystems in Australia: structure, function and managenment. Canberra: Australian National University Press, 1982. p.317.

THOM, B.G. Coastal landforms and geomorphic processes. In: SNEDAKER, S.C.; SNEDAKER, J.G. The mangrove ecosystem: research methods. Paris: UNESCO, SCOR, 1984. p.3-17.

TORSVIK, V.; DAAE, F.L.; SANDAA, R.A; OVREAS, L. Novel techniques for analyzing microbial diversity in natural and perturbed environments. Journal of Biotechnology, v.64, p.53-62, 1998.

TORSVIK, V.; GOKSOYR, J.; DAAE, F.L. High diversity in DNA of soil bacteria. Applied Environmental Microbiology, v.56, p.78-787, 1990.

TUNDISI, J.; TEIXEIRA, C. TUNDISI, T.M.; KURNER, M.B.; KINOSHITA, L. Plankton studies in a mangrove environment. IX. Comparative investigations with coastal oligotrophic waters. Revista Brasileira de Biologia, v.38, n.2, p.301-320, 1978.

UKPONG, L.E. Mangrove swamp at a saline/fresh water interface near Creek Town, Southeastern Nigeria. Catena, v.29, p.61-71, 1997. 
VANCE, E.D.; BROOKES P.C.; JENKINSON D.S. An extraction method for measuring soil microbial biomass C. Soil Biology and Biochemistry, v.19, p.703-707, 1987.

VANNUCCI, M. Os manguezais e nós: uma síntese de percepções. São Paulo: EDUSP, 1999. 233p.

VETRIANI, C.; JANNASCH, H.W.; MacGREGOR, B.J.; STAHL, D.A.; REYSENBACH, A.L. Population structure and phylogenetic characterization of marine benthic Archaea in deep-sea sediments. Applied and Environmental Microbiology, v.65, n.10, p.4375-4384, 1999.

WALSH, G.E. Mangroves: a review. In: REINOLD, R.J.; QUEEN, W.H. (Ed.) Ecology of halophytes. New York: Academic Press, 1974. p.51-154

WARDLE, D.A. Metodologia para quantificação da biomassa microbiana do solo. In: HUNGRIA, M; ARAÚJO, R.S. (Ed.). Manual de métodos empregados em estudos de microbiologia agrícola. Brasília: Embrapa, 1994. cap.21, p.419-436.

WHITMAN, W.B.; COLEMAN, D.C.; WIEBE, W.J. Prokaryotes: the unseen majority. Proceedings of the National Academy of Sciences of the U.S.A., v.95, p.6578-6583, 1998.

WOODHOUSE, W.W.;SENECA, E.D.; BROOME, S.W. Propagation of Spartina Alterniflora for substrate stabilization and salt-marsh development. Fort Belvoir: U.S. Army Coastal Engineering Research Center, 1974. 155p. (Technical Memo, 46). 
WOODWELL, G.M.; WHITNEY, D.E.; HALL, C.A.S.; HOUGHTON, R.A.. The flax pond ecosystem study: Excahnges of carbon in water between a salt marsh and Long island Sound. Limnology and Oceanography, v.22, n.5, p.833-838, 1977.

WUNSCHE, L.; BRUGGEMANN, L.; WOLFGANG B. Determination of substrate utilization patterns of soil microbial communities: An approach to assess population changes after hydrocarbon pollution. FEMS Microbiology Ecology, v.17, p.295-306, 1995.

YAÑEZ-ARANCIBIA, A. Ecologia de la zona costera: analisis de siete tópicos. México: A.G.T. Ed., 1986. 189p.

ZAK, J.C.; WILLIG, M.R.; MOORHEAD, D.L.; WILDMAN, H.G. Functional Diversity of microbial communities: a quantitative approach. Soil Biology and Biochemistry, v.26, p.1101-1108, 1994.

ZHOU, J.; XIA, B.; TREVES, D.S.; WU, L.Y.; MARSH, T.L.; O’NEILL, R.V.; PALUMBO, A.V.; TIEDJE, J.M. Spatial and resource factors influencing high microbial diversity in soil. Applied and Environmental Microbiology, v.86, n.1, p.326-334, 2002. 